Prepared in cooperation with the

South Carolina Sea Grant Consortium

\title{
Coastal Change Along the Shore of Northeastern South Carolina-The South Carolina Coastal Erosion Study
}

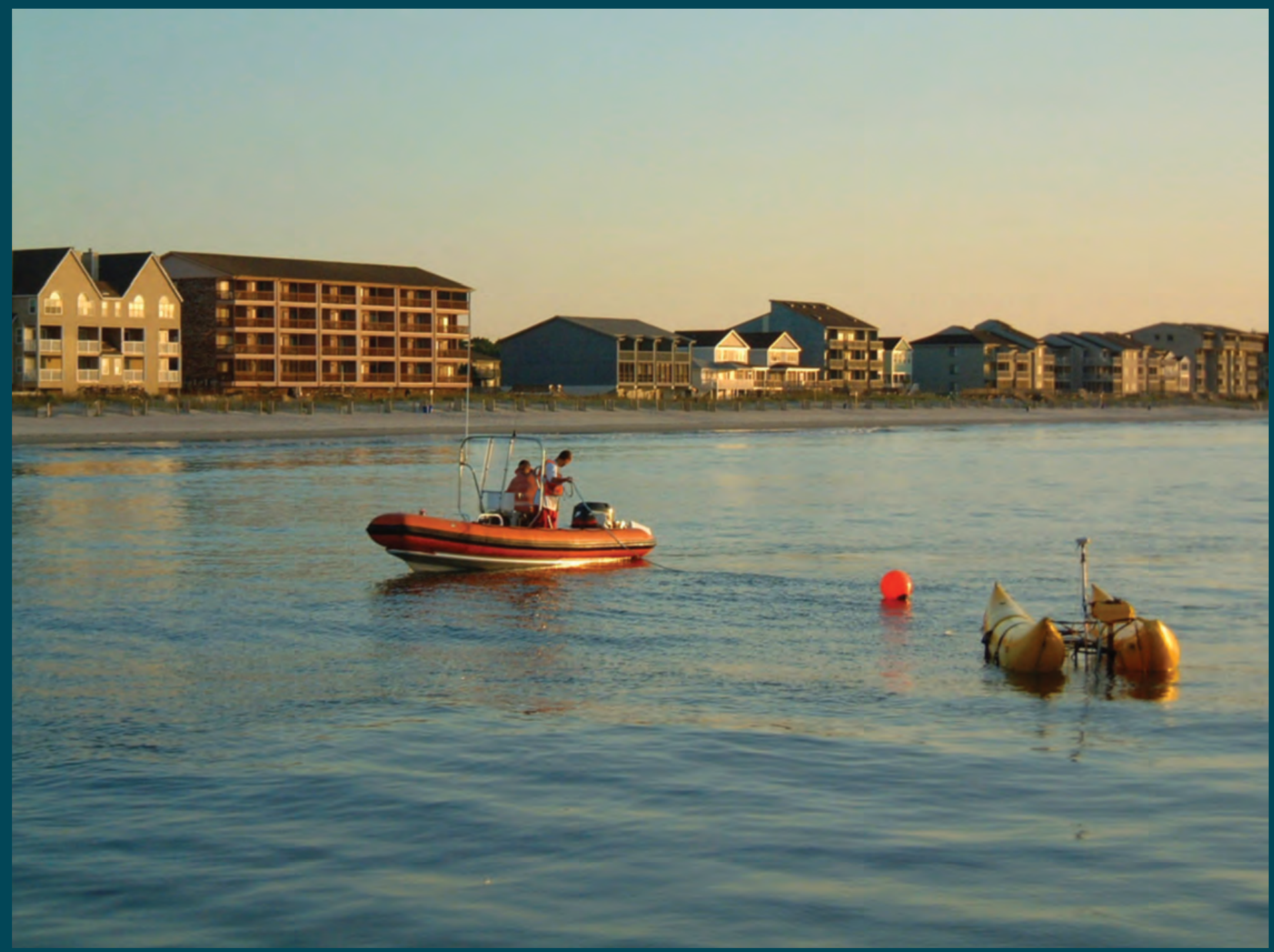

Circular 1339 


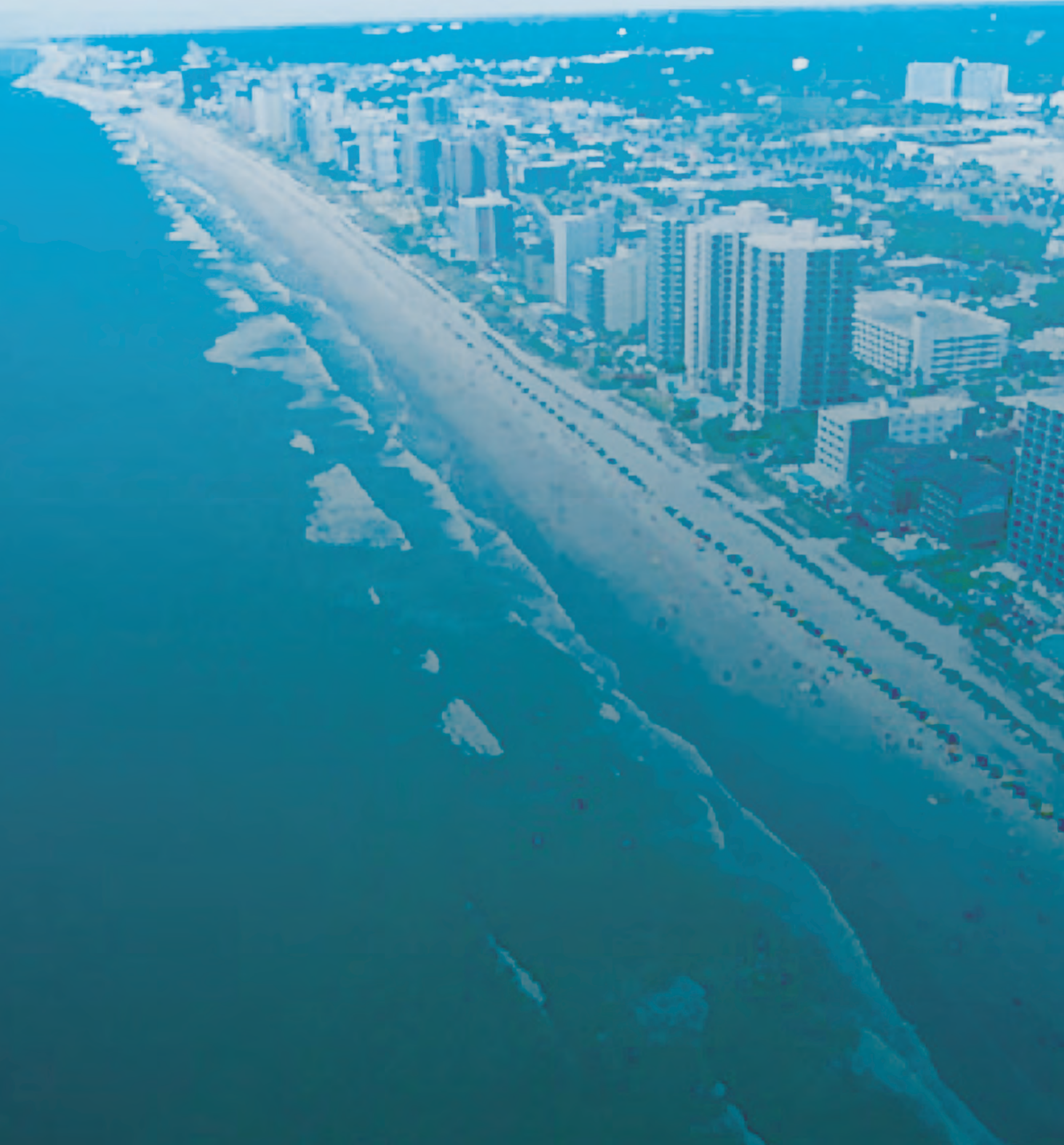

Cover. Photograph showing geologists towing a subbottom profiler (yellow pontoons) in shallow water near the beach. 


\title{
Coastal Change Along the Shore of Northeastern South Carolina- The South Carolina Coastal Erosion Study
}

\author{
Edited by Walter A. Barnhardt
}

Contributing authors:

W.C. Schwab', P.T. Gayes², R.A. Morton ${ }^{3}$, N.W. Driscoll', W.E. Baldwin', W.A. Barnhardt', J.F. Denny ${ }^{1}$, M.S. Harris ${ }^{5}$, M.P. Katuna ${ }^{5}$, T.R. Putney ${ }^{6}$, G. Voulgaris ${ }^{7}$, J.C. Warner ${ }^{1}$, and E.E. Wright ${ }^{2}$

'U.S. Geological Survey, Woods Hole, MA ${ }^{2}$ Coastal Carolina University, Conway, SC

${ }^{3}$ U.S. Geological Survey, St. Petersburg, FL

${ }^{4}$ Scripps Institution of Oceanography, La Jolla, CA

${ }^{5}$ College of Charleston, Charleston, SC

${ }^{6}$ General Engineering and Environmental, LLC, Charleston, SC

?University of South Carolina, Columbia, SC

Prepared in cooperation with the

South Carolina Sea Grant Consortium

Circular 1339 


\title{
U.S. Department of the Interior KEN SALAZAR, Secretary
}

\section{U.S. Geological Survey Suzette M. Kimball, Acting Director}

\author{
U.S. Geological Survey, Reston, Virginia: 2009 \\ This circular supersedes U.S. Geological Survey Open-File Report 2008-1206
}

For more information on the USGS — the Federal source for science about the Earth, its natural and living resources, natural hazards, and the environment, visit http://www.usgs.gov or call 1-888-ASK-USGS

For an overview of USGS information products, including maps, imagery, and publications, visit http://www.usgs.gov/pubprod

To order this and other USGS information products, visit http://store.usgs.gov

Neither the U.S. Government, the Department of the Interior, nor the USGS, nor any of their employees, contractors, or subcontractors, make any warranty, express or implied, nor assume any legal responsibility for the accuracy, completeness, or usefulness of any information, apparatus, product, or process disclosed, nor represent that its use would not infringe on privately owned rights. The act of distribution shall not constitute any such warranty, and no responsibility is assumed by the USGS in the use of these data or related materials.

Any use of trade, product, or firm names is for descriptive purposes only and does not imply endorsement by the U.S. Government.

Although this report is in the public domain, permission must be secured from the individual copyright owners to reproduce any copyrighted materials contained within this report.

Suggested citation:

Barnhardt, W.A. (ed.), 2009, Coastal change along the shore of northeastern South Carolina-the South Carolina coastal erosion study: U.S. Geological Survey Circular 1339, 77 p.

\section{Library of Congress Cataloging-in-Publication Data}

Coastal change along the shore of northeastern South Carolina : the South Carolina coastal erosion study / edited by Walter A. Barnhardt; contributing authors: W.C. Schwab ... [et al.] ; prepared in cooperation with the South Carolina Sea Grant Consortium.

p. cm. -- (Circular ; 1339)

Includes bibliographical references.

ISBN 978-1-4113-2538-8 (alk. paper)

1. Coast changes--South Carolina. 2. Beach erosion--South Carolina. 3. Shore protection--South Carolina.

I. Barnhardt, Walter A., 1960- II. Schwab, William C. III. South Carolina Sea Grant Consortium.

GB459.5.C63 2009

$551.45^{\prime} 7--d c 22$ 


\section{FOREWORD}

Coastal erosion and shoreline change are major concerns in South Carolina, because of the threat they pose to developed coastal communities, public infrastructure, an annual $\$ 15$ billion tourism industry, and the state's commercial and recreational fishing enterprises. Rapid population growth and human alteration of the shoreline underscore the region's vulnerability to the effects of sea-level rise and coastal storms. The South Carolina Coastal Erosion Study focused on understanding the processes that control erosion along the Grand Strand coast and providing resource managers with essential information for maintaining healthy beaches. The research program described in this report represents a model partnership among Federal, State, and academic institutions through a cooperative arrangement between the U.S. Geological Survey (USGS) and the South Carolina Sea Grant Consortium.

Addressing the challenges of a shifting shoreline requires a strong understanding of the physical, economic, and socio-demographic factors that shape it. Geologic mapping of the coast and seafloor, long-term measurements of waves and tides, and numerical modeling of sediment movement were carried out by faculty and students from Coastal Carolina University, University of South Carolina, College of Charleston, Clemson University, Scripps Institution of Oceanography, and University of New Hampshire in collaboration with the USGS Coastal and Marine Geology Program. The results of these studies have allowed state and federal resource managers to quantify patterns of shoreline change in the region, determine the location and quality of sand resources for beach nourishment, identify critical fisheries habitat such as hard bottom areas, and explore interest in alternative offshore energy development. South Carolina coastal communities - from Charleston to North Myrtle Beach - have realized considerable cost savings by using the data and information generated by this study to make important decisions about beach nourishment, the offshore disposal of dredge material, and the siting of ocean outfall locations.

The South Carolina Coastal Erosion Study has provided enormous benefits to a variety of coastal constituencies in a highly leveraged, cost-effective manner. The federal-state-university partnership enabled through this collaboration can serve as a model for similar studies elsewhere in the nation, where the engagement of government and university scientists, students, managers and decision-makers in cutting edge research and issues of direct importance to our society are most critical.

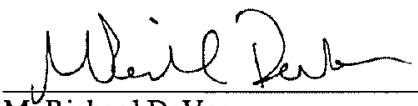

M. Richard DeVoe Executive Director S.C. Sea Grant Consortium Charleston, SC

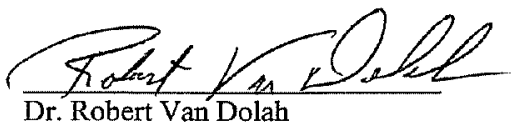

Dr. Robert Van Dolah Director SCDNR - Marine Resources Research Institute Charleston, SC

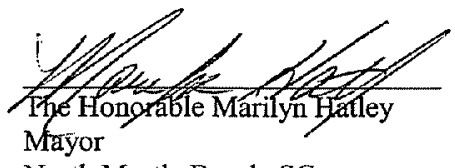

North Myrtle Beach, SC
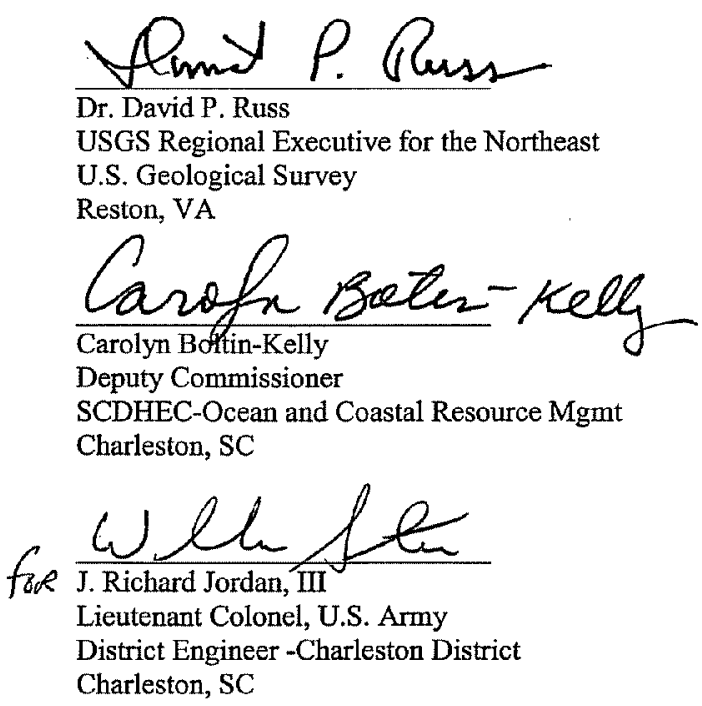


\section{Acknowledgments}

Funding for this research was provided by the Coastal and Marine Geology Program of the U.S. Geological Survey (USGS) and the South Carolina Sea Grant Consortium (SCSGC). We thank M. Richard (Rick) Devoe, Director of the SCSGC, for his encouragement and support of coastal research. William Danforth, David Nichols, Thomas O'Brien, Barry Irwin, Kenneth Parolski, Charles Worley, Shawn Dadisman (USGS), and Paul Byham (SEA Ltd.) provided support during data acquisition and processing. Neal Gielstra, Jenna Hill, Elizabeth Johnstone, German Ojeda, Jamie Phillips, Beth Sharrer, Triniti Dufrene, Melody van der Linde, Trent P. Tinker, Amanda Windsor, Elizabeth Gherman, and Heather Young (Coastal Carolina University) provided invaluable logistical and technical assistance. Sarah Kruse (University of South Florida) and Steven Forman (University of Illinois at Chicago) provided scientific analyses and interpretations. Jennifer Martin arranged this document in HTML. We also thank the captains and crews of the R/V Atlantic Surveyor, R/V Megan Miller, and R/V Coastal II. This report greatly benefited from reviews by C. Wiley Poag, E. Robert Thieler, and Eric Grossman. 


\section{Contents}

Section 1: Coastal Change: Implications for the Grand Strand................. 2

Section 2: Mapping Coastal Change ................................................................18

Section 3: Geologic Framework...................................................................32

Section 4: Shoreline Change ............................................................................46

Section 5: Sediment Budget and Ocean Processes ........................................58

Section 6: An Effective Strategy for Understanding Coastal Change.........70

Section 7: References Cited .........................................................................72

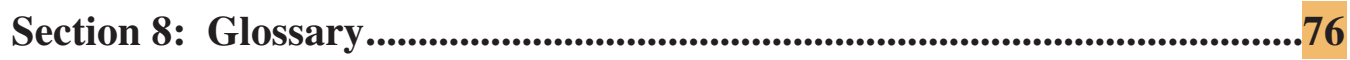




\section{Conversion Factors and Abbreviations}

SI to Inch/Pound

\begin{tabular}{lll}
\hline \multicolumn{1}{c}{ Multiply } & \multicolumn{1}{c}{ By } & \multicolumn{1}{c}{ To obtain } \\
\hline centimeter $(\mathrm{cm})$ & Length & \\
millimeter $(\mathrm{mm})$ & 0.3937 & inch (in.) \\
meter $(\mathrm{m})$ & 0.03937 & inch (in.) \\
kilometer $(\mathrm{km})$ & 3.281 & foot (ft) \\
\hline & 0.6214 & mile $(\mathrm{mi})$ \\
\hline square kilometer $\left(\mathrm{km}^{2}\right)$ & Area & \\
\hline & 0.3861 & square mile $\left(\mathrm{mi}^{2}\right)$ \\
\hline cubic meter $\left(\mathrm{m}^{3}\right)$ & Volume & \\
\hline & 1.308 & cubic yard $\left(\mathrm{yd} \mathrm{d}^{3}\right)$ \\
\hline meter per second $(\mathrm{m} / \mathrm{s})$ & Flow rate & foot per second $(\mathrm{ft} / \mathrm{s})$ \\
meter per year $(\mathrm{m} / \mathrm{yr})$ & 3.281 & foot per year $(\mathrm{ft} / \mathrm{yr})$ \\
millimeter per year $(\mathrm{mm} / \mathrm{yr})$ & 3.281 & inch per year $(\mathrm{in} / \mathrm{yr})$ \\
kilometer per second $(\mathrm{km} / \mathrm{s})$ & 0.03937 & mile per second $(\mathrm{mi} / \mathrm{s})$ \\
\hline & 0.6214 & \\
\hline kilogram $(\mathrm{kg})$ & Mass & pound avoirdupois $(\mathrm{lb})$ \\
\hline
\end{tabular}

\begin{tabular}{ll}
\hline ACRONYMS & \multicolumn{1}{c}{ DEFINITIONS } \\
\hline ATV & All terrain vehicle \\
BERM & Beach erosion and monitoring project \\
GIS & Geographic information system \\
GPR & Ground penetrating radar \\
LIDAR & Light detection and ranging \\
MCPH & Mid-Carolina Platform High \\
MSL & mean sea level \\
NOS & National Ocean Service (National Oceanographic and \\
& Atmospheric Administration) \\
OCRM & Ocean and Coastal Resource Management (South Carolina \\
SCCES & Department of Health and Environmental Control) \\
SL & South Carolina Coastal Erosion Study \\
USACE & Sea level \\
USGS & U.S. Army Corps of Engineers
\end{tabular}




\subsection{Introduction}

Coastal and nearshore marine environments are dynamic natural systems that continually evolve or change over time. In the United States, barrier islands that protect most of the Atlantic and Gulf Coasts have, on the whole, moved landward over many centuries. To a geologist or oceanographer, the landward migration is a natural response to storms, sea-level rise, and other processes that operate at the ocean's edge. To an owner of beachfront property, however, this coastal change is simply erosion. By identifying the agents responsible for coastal change and determining the relative contribution of each agent, scientists and policy makers can address the underlying causes of beach erosion, wetland loss, and other challenging issues. The development and application of science-based management strategies will help to conserve coastal environments while ensuring that they remain places the public can continue to safely inhabit and enjoy.

Coastal change is a major concern along many segments of the world's coastlines. Rapid population growth over recent decades has increased pressure on what remains of natural coastal environments. More than half the U.S. population lives in coastal counties, which account for only 17 percent of the land area of the nation (Beach, 2002). Most of these coastal areas are actively eroding or are otherwise vulnerable to rising sea level (Dolan and others, 1985; Thieler and Hammar-Klose, 1999, 2000a, 2000b). Human activities, such as seawall construction and channel dredging, have reduced sediment supply to beaches, interrupted the natural movement of sediment along the coast, and modified the normal flow of water through inlets and estuaries. Additionally, processes associated with storms and sea-level rise have profoundly shifted the position of the shoreline by eroding beaches and flooding low-lying areas (fig. 1.1). These processes act over different time scales to drive coastal change, which in turn threatens the infrastructure and economies of many coastal communities.

An increase in the rate of sea-level rise is expected as a result of global warming over the $21 \mathrm{st}$ century, according to a report by the Intergovernmental Panel on Climate Change (IPCC, 2007). Projections of sea-level rise have been the topic of much debate, especially regarding the potential contribu- tions made by melting of ice sheets in Greenland and Antarctica (CCSP, 2009). Conservative estimates call for at least $0.5 \mathrm{~m}$ of sea-level rise by the year 2100 , but plausible scenarios range up to $2 \mathrm{~m}$ higher than present depending on rates of ice loss (Rahmstorf, 2007; Pfeffer and others, 2008). Even the low end of these estimates is considerably faster than the rate observed over the previous 100 years (Douglas, 1997). Global warming is also expected to produce higher sea-surface temperatures, which have been linked to more frequent and more powerful hurricanes (Emanuel, 2005; Webster and others, 2005). If this linkage is real, years of relatively quiet storm activity will come to an end for many coastal areas. Beach towns might face severe societal and
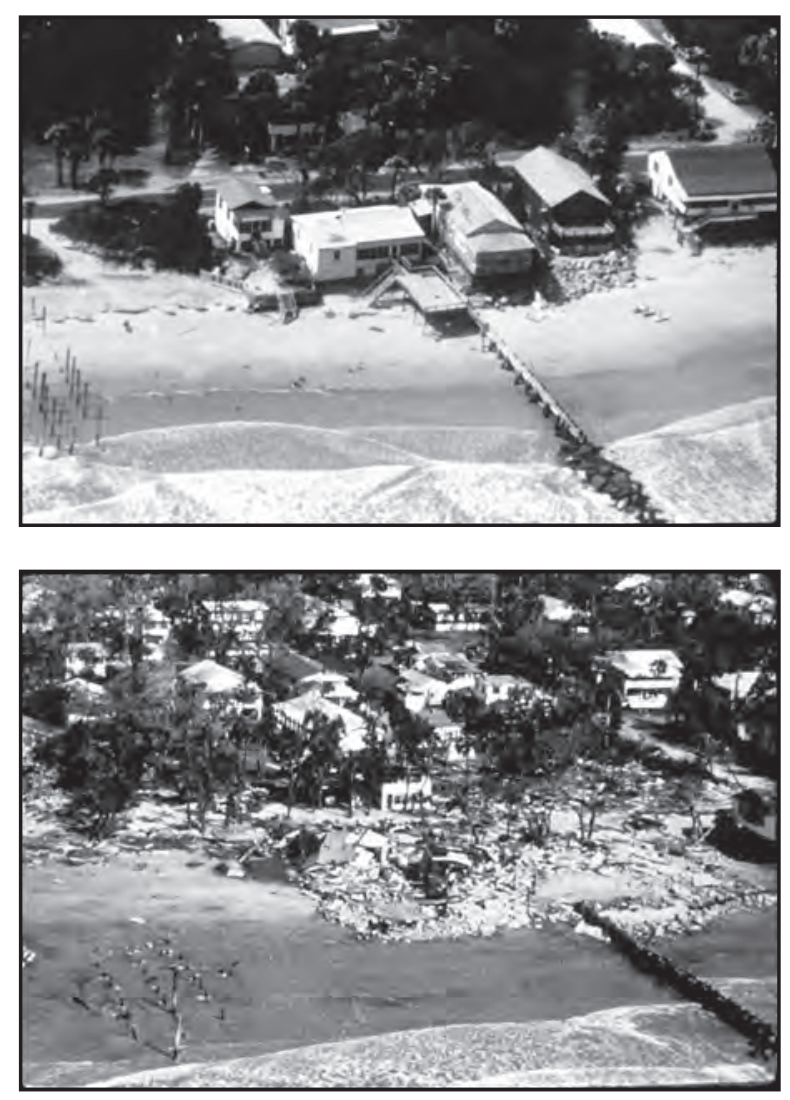

Figure 1.1. The beach at Folly Island taken before (top) and after (bottom) Hurricane Hugo struck the coast of South Carolina in October 1989. Published by permission of the National Oceanic and Atmospheric Administration Photo Library (accessed online July 1, 2007, at http://www. photolib.noaa.gov). 
economic upheaval such as that recently experienced by residents of the Gulf Coast during active hurricane seasons. The scientific community generally lacks the ability to predict these effects on time scales short enough to be useful in making land-use decisions such as locating new construction or issuing permits for other activities. However, resource managers and policy makers need reliable information to predict when, where, and how much the coast will change.

Changes in the morphology of coastal landforms and patterns of sediment movement have been studied for over a century, but, in general, scientists have only a rudimentary understanding of the processes that drive coastal change. For example, we know that the shapes of sandy shorelines are largely dictated by waves, tides, and currents that act across a wide spectrum of spatial and temporal scales. Whereas a single storm can dramatically transform a section of coastline overnight, the impacts of sea-level rise take place over decades or centuries. That storm might deeply erode a beach in only a few hours, but the sediment is not necessarily lost forever. Gentle swells from prolonged periods of fair weather following the storm typically return sediment to the beach (fig. 1.2). As the frequency and intensity of storms vary each year, so too does the condition of the beach.

The U.S. Geological Survey (USGS) conducts regional studies of coastal erosion to provide impartial scientific information necessary for the protection and management of valuable coastal resources. This report summarizes the results of a multidisciplinary study of the northeastern coast of South Carolina by the USGS in cooperation with the South Carolina Sea Grant Consortium (SCSGC) from 1999 to 2006. The main objective of the study was to determine the geologic and oceanographic processes that control sediment movement along the region's shoreline and thereby improve projections of coastal change.

\subsection{The Grand Strand}

\section{Physical Setting}

The nearly continuous series of sandy beaches in northeastern South Carolina is commonly known as the "Grand Strand." This arcuate segment of coast extends $100 \mathrm{~km}(62 \mathrm{mi})$ along the central and southern portions of Long Bay, a large embayment that lies between Cape Fear, North Carolina, and Cape Romain, South Carolina (fig. 1.3). The broad, crescent-shaped shoreline is characteristic of regions where seasonal changes in wind directions produce waves that move sediment alternately up and down the coast. Waves are more important than tides in moving sediment along the Grand Strand, which has a low mean tidal range of $1.5 \mathrm{~m}$. These microtidal conditions typically result in narrow barrier islands that are separated by small tidal inlets (Hayes, 1994). Presently, beaches in the region receive little or no sediment from rivers. Sediment carried by the Pee Dee River, which discharges into Winyah Bay at the southern end of the Grand Strand, is trapped upstream behind dams or in the estuary before it reaches the coast (Patchineelam and others, 1999).

Barrier islands and spits are limited to the northern and southern ends of the Grand Strand and are not present in the center (fig. 1.3). Waites Island, a small undeveloped barrier island near the North Carolina border, is separated from the mainland by a narrow estuary and salt marshes. The central part of the Grand Strand consists of mainland-attached beaches with residential and commercial development built close to the beach (Lennon and others, 1996). No tidal inlets are present in the stretch of coast between Cherry Grove and Garden City Beach. Along this stretch, beaches directly abut the mainland shore, which reaches elevations as high as $11 \mathrm{~m}$ above local mean sea level. The character of the coast again changes between Murrells Inlet and Winyah Bay in the southwestern part of Long Bay, where short barrier islands and spits are separated from the mainland by narrow estuaries.

This study focuses on terrestrial and marine environments in a swath that extends 5 to $15 \mathrm{~km}$ landward and $10 \mathrm{~km}$ seaward of the Grand Strand coastline. Inland, the study area includes the popular resort cities of Myrtle Beach, North Myrtle Beach, Surfside Beach, and several smaller coastal communities. Seaward, it covers the nearshore portion of the Long Bay inner continental shelf from the surf zone to water depths of about $15 \mathrm{~m}$. The low-relief seafloor slopes seaward at relatively steep gradients up to $4 \mathrm{~m} / \mathrm{km}$ in nearshore areas (Denny and others, 2007). Beyond the 7-m isobath, the slope decreases to $1 \mathrm{~m} / \mathrm{km}$ or less. 


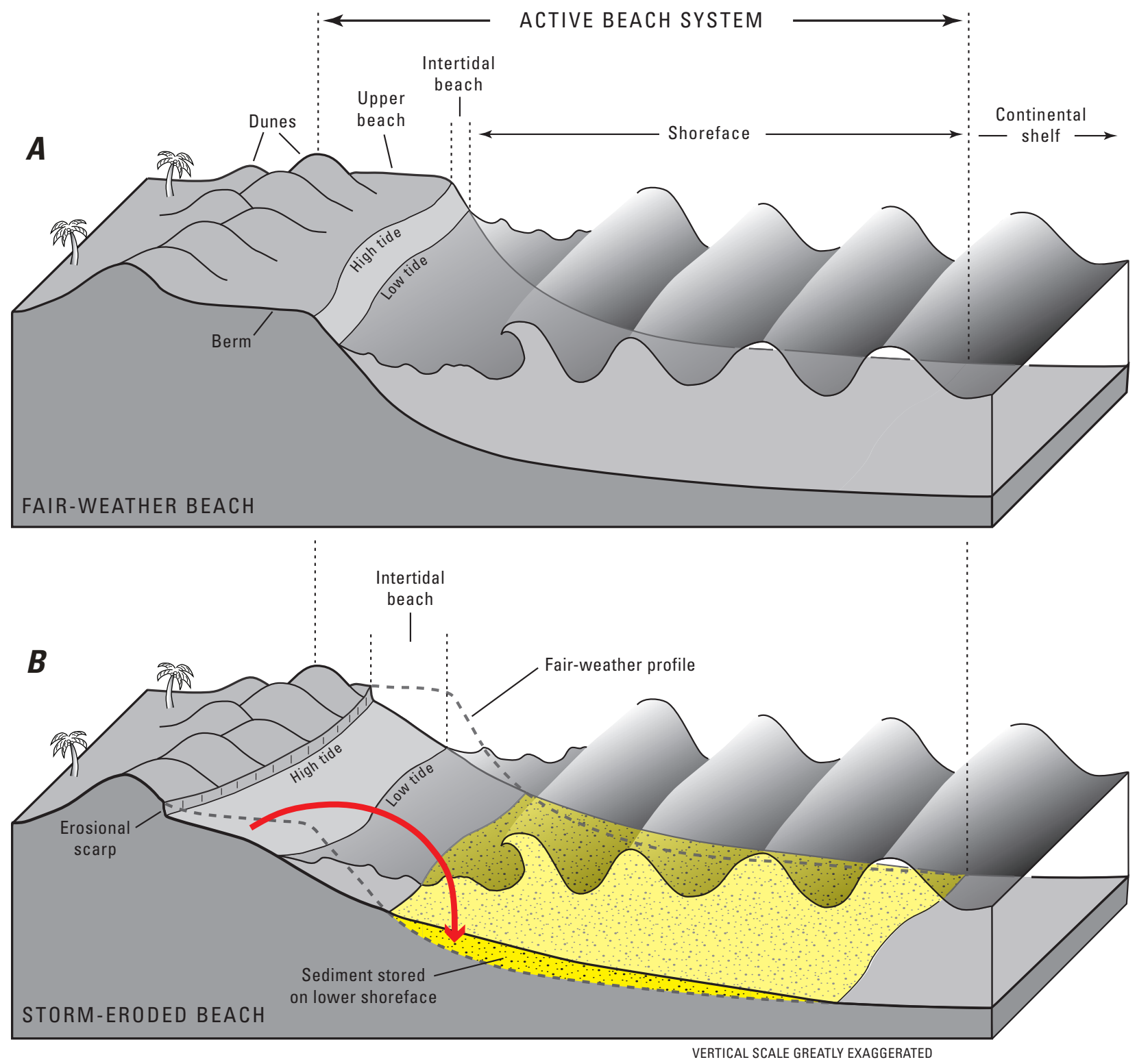

Figure 1.2. The active beach system, which extends from the dunes to the inner edge of the continental shelf. (A) During fair weather, sediment is stored in the upper beach and dunes. The relatively broad, flat berm is dry at high tide. The intertidal beach is relatively narrow, and the seaward-sloping shoreface forms a concave-upward surface beneath the waves. (B) During stormy weather, waves and currents erode the berm and dunes. Sediment is transported offshore into deeper water (red arrow) and produces a broader, more gently sloping intertidal beach and shoreface. Sediment temporarily stored offshore typically moves back onto the beach in the weeks and months following a storm. 
A
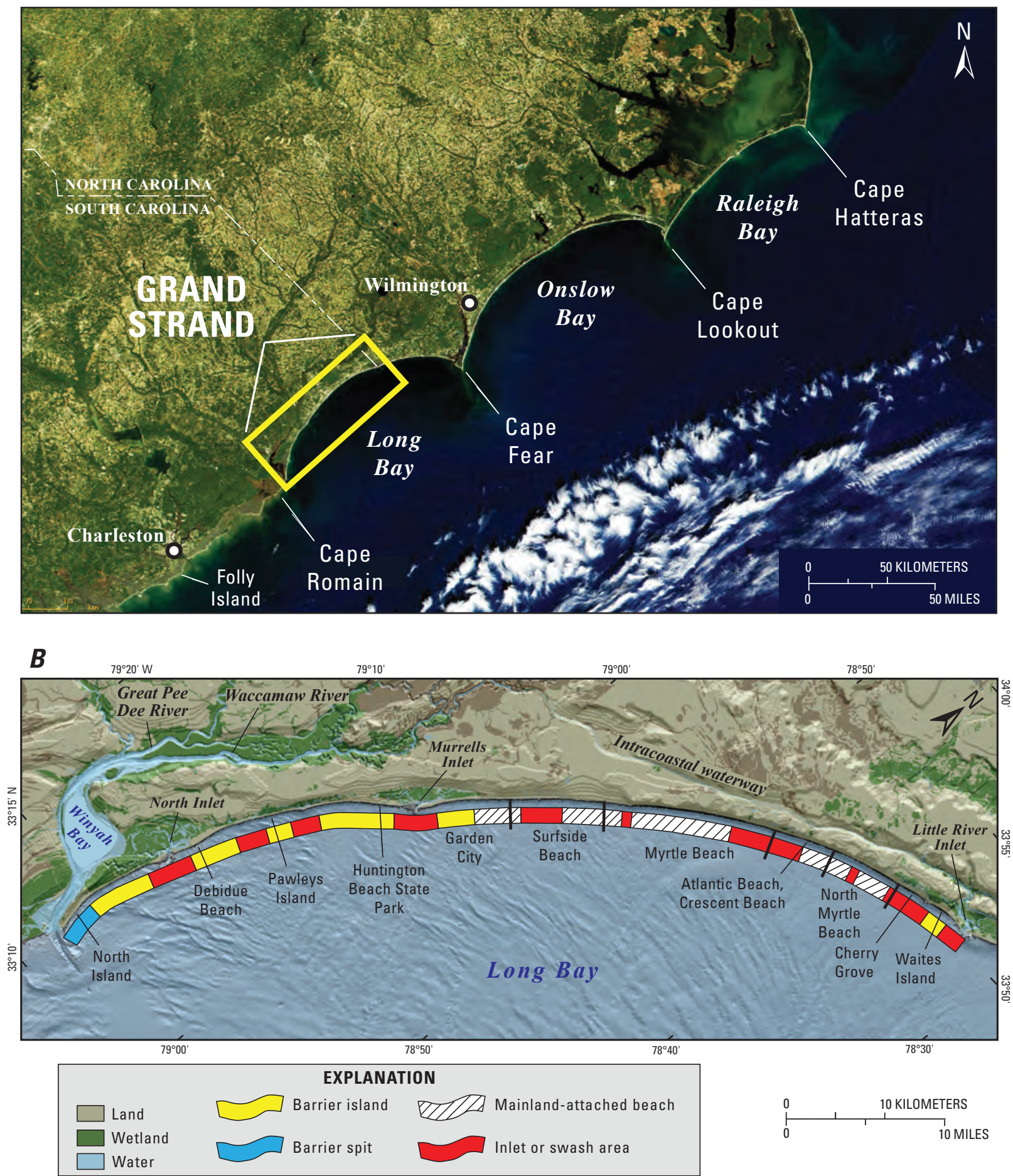

Figure 1.3. (A) The location of the Grand Strand study area on the North and South Carolina coasts. Published by permission of the National Aeronautics and Space Administration-Visible Earth program accessed July 1, 2007, online at http://visibleearth.nasa.gov/. (B) Physiographic and geographic features of the Grand Strand. Types of coastal landforms are indicated by the color-coded bands parallel to the coast. 


\section{Population, Economy, and Development}

The sandy beaches of the Grand Strand have attracted year-round residents and recreational visitors since the mid-1800s, when coastal development first began in the region. Since that time the Grand Strand has become increasingly popular as a tourist destination and as a home for many new residents. The population of Horry and Georgetown Counties was recently estimated at almost 300,000 (U.S. Census Bureau, 2008). The 36.5-percent increase in the number of year-round residents during the past decade (1990-2000) has made the two counties together the 13th fastest growing metropolitan area in the nation. A robust tourism industry annually draws about 14 million visitors and generates over $\$ 2$ billion in direct visitor expenditures (Myrtle Beach Area Chamber of Commerce, 2008). Tourism revenues produced along the Grand Strand account for more than 30 percent of the annual statewide total (2000-04); this revenue represents an economic boon for the region as well as an important source of income for the State.

A dramatic increase in residential, commercial, and infrastructure development (fig. 1.4) has accompanied this growth surge and has underscored the vulnerability of the Grand Strand to the perils of its coastal location. The continued economic success of the region and the quality of life that local residents enjoy are inherently tied to the integrity and quality of maintenance of local beaches. The beaches provide the recreational potential that drives the local tourism economy and, more importantly, protection from the impacts of storms and coastal erosion. With ongoing sea-level rise, beach erosion is expected to continue or possibly worsen, jeopardizing the future of the Grand Strand as a premier seaside resort.

\subsection{Coastal Hazards}

\section{Sea Level}

Global sea level has fluctuated widely due to climate changes and tectonic influences. Sea level falls during glacial periods, commonly referred to as Ice Ages, because large volumes of water evaporate from the oceans and become incorporated into ice sheets (see Box \#1). The opposite occurs during interglacial periods such as today, when the climate is warmer, and melting ice returns water to the oceans. Warmer ocean water also expands, causing additional sea-level rise. In response to these changes in sea level, coastal systems have migrated across the continental shelf and coastal plain of South Carolina (fig. 1.5). These landscapes are flat and gently sloping, so a small rise in sea level can inundate a broad area of land. The shoreline moves landward as sea level rises. When sea level reaches its maximum elevation, movement of the shoreline slows to a stop. Sediment has more time to accumulate while the coast remains in one position, so barrier islands and other shoreline deposits develop and grow.

The Atlantic Ocean has flooded nearly all of the South Carolina coastal plain during the geologic past during repeated cycles of sea-level rise and fall. The generally flat coastal plain steps down toward the ocean in a series of terraces that are aligned northeastsouthwest, roughly parallel to the Grand Strand coast. The terraces are separated by erosional escarpments and low linear hills that represent ancient shorelines (fig. 1.6). The shoreline features formed at times of high sea level over the last 3-4 million years. The Orangeburg Scarp, the oldest shoreline, lies more than $100 \mathrm{~km}$ landward of Myrtle Beach. It was formed by wave erosion when the coast was west of the cities of Florence and Sumter. These erosional scarps and shoreline deposits progressively decrease in age and elevation towards the modern coast (DuBar and others, 1974; Colquhoun and others, 1991), where a new escarpment is currently forming along the Grand Strand. Although these ancient shoreline features are indicative of sea-level changes in the distant past, the record that they provide is largely incomplete. Old shorelines also formed seaward of the modern coast when sea level was lower than present, but most evidence has been eroded away by ocean processes.

Sea level has slowly continued to rise over the course of our lifetimes. Tide-gauge records from around the world indicate that global sea level increased at an average rate of about $2 \mathrm{~mm} / \mathrm{yr}$ during the 19th and 20th centuries (Douglas, 1997). Longterm records from Charleston show that the rate of sea-level rise is considerably higher along the South Carolina coastline, where it is estimated at $3.28 \mathrm{~mm} / \mathrm{yr}$. As sea level slowly continues to rise, lowlying coastal areas will be inundated, and the beaches, barriers, and marshes of the Grand Strand coastal system will continue to migrate landward. Waves and 

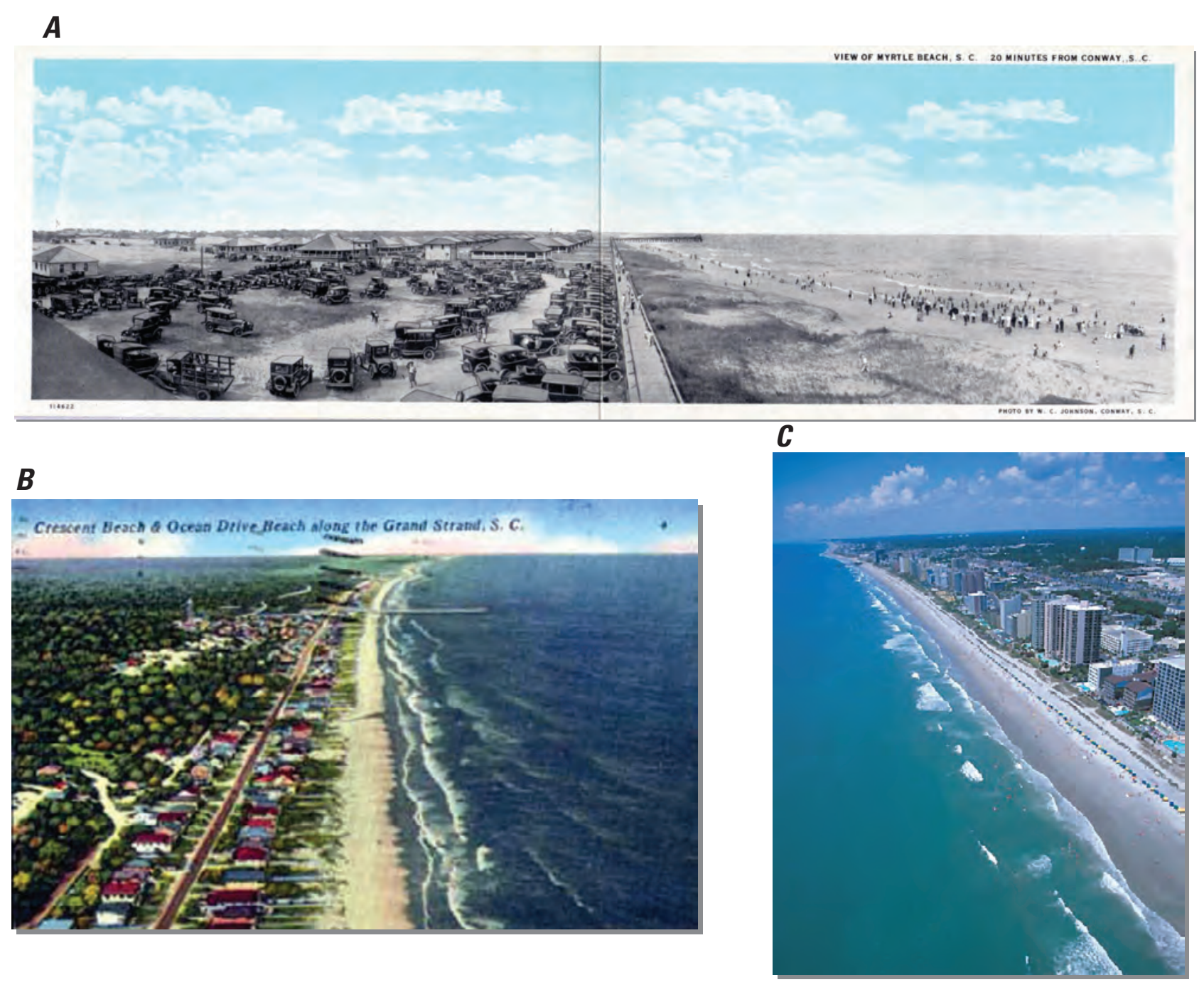

Figure 1.4. Views of the Grand Strand before and after high-density oceanfront development. (A) Picture postcard of Myrtle Beach Pavilion area with boardwalk and small structures behind a natural dune. Photograph taken by W.C. Johnson around 1927 and published by permission of the Lake County (IL) Discovery Museum, Curt Teich Postcard Archives. (B) Picture postcard of the Crescent Beach and Ocean Drive Beach sections of North Myrtle Beach around 1955. Published by permission of the South Caroliniana Library, University of South Carolina-Columbia. During this period, single-family cottages represented most of the development, and, although structures did stand close to the shoreline, the integrity of coastal dunes was preserved. (C) Photograph of oceanfront along the downtown section of Myrtle Beach around 2000 (published by permission of the Myrtle Beach Area Convention and Visitors Bureau). High-rise condominiums and hotels now dominate development along the Grand Strand. In many areas, structures stand directly adjacent to the beach and frontal dunes are absent. Locations shown on figure 1.3B. 


\section{BOX \#1: SEA-LEVEL CHANGE}

Graphs A through C illustrate sea-level changes that occur over different time and spatial scales.

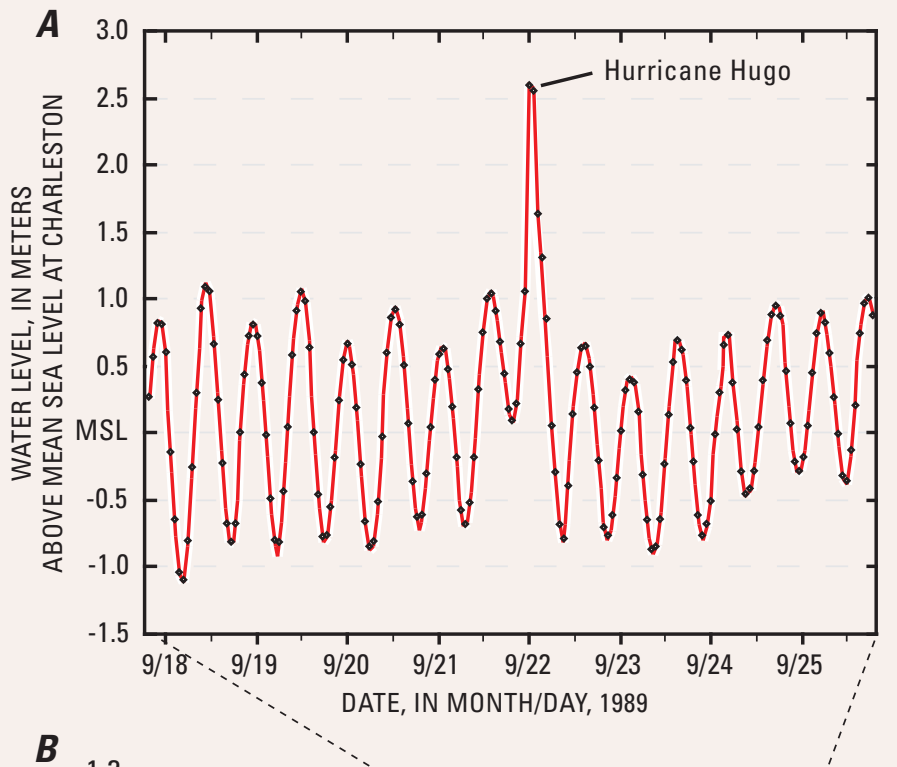

\section{A. EVENT SCALE (hours to days).}

The tide gauge at Charleston Harbor shows variations in water levels due to tides and an anomalously high tide when Hurricane Hugo made landfall at midnight on September 21, 1989. The storm surge rose $2.6 \mathrm{~m}(8.0 \mathrm{ft})$ above mean sea level (MSL) at Charleston and over $6 \mathrm{~m}$ $(20 \mathrm{ft})$ above MSL in coastal areas $\mathbf{2 0} \mathrm{mi}$ to the north (Brennan, 2001). Data from NOAA National Ocean Service (http://tidesonline.nos.noaa.gov/).

\section{B. HISTORICAL SCALE (decades to centuries).}

Tide-gauge records depict fluctuations in the elevation of mean high water (MHW) from 1900 to 2005. Monthly averages (black dots) are overlain with a curve showing the annual average (red line). The long-term trend in sea-level rise is about $3.3 \mathrm{~mm} / \mathrm{year}$ (1.1 $\mathrm{ft} /$ century). Data from NOAA National Ocean Service (http://tidesonline.nos. noaa.gov/).

\section{GEOLOGICAL SCALE (thousands of years).}

Large changes in global sea level have occurred because of glacial cycles and changes in continent-based ice volumes. Geologic evidence shows that about 120,000 years ago sea level was at or above its present elevation. Barrier islands existed along the South Carolina coast, much like today. Sea level later fell as glaciers grew during the last Ice Age and, about 21,000 years ago, the shoreline was far out on the continental shelf. Since that time, climate warming and melting glaciers have driven the ongoing rise in sea level and general landward migration of the shoreline to its present position. Figure modified from Lambeck and Chappell (2001, their figure 1B). 
Images D through $\mathrm{F}$ display the impacts of sea-level changes on coastal areas that range from local flooding due to storm surges to long-term migration of shorelines across the region due to climate-driven increases in sea level.
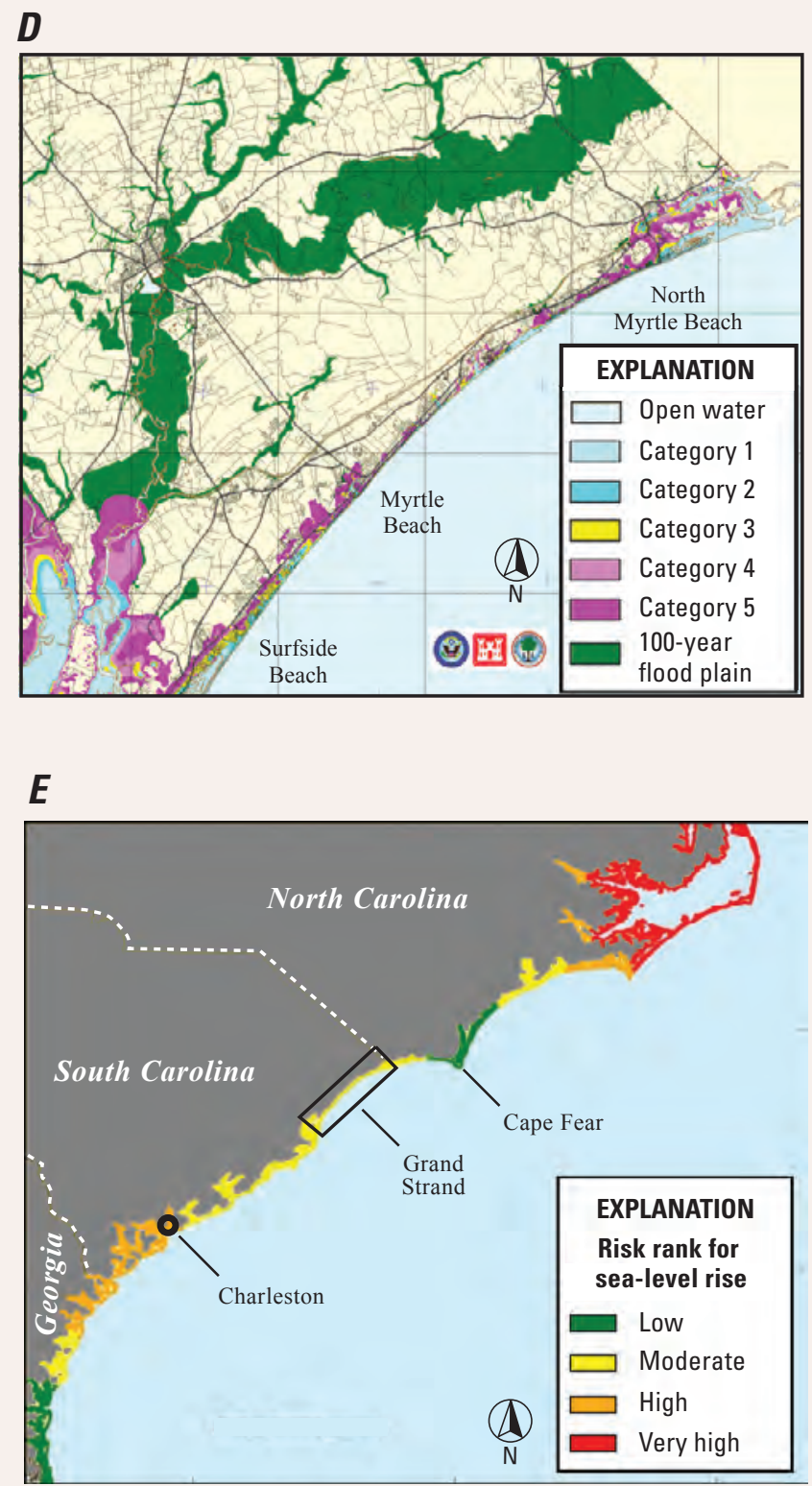

E. SEA-LEVEL RISE (decades to centuries).

Image showing the risk from sea-level rise along the North Carolina to Georgia coast. The risk is lowest in the vicinity of Cape Fear because of the relatively high slope of the upland adjacent to the coast. Modified from Thieler and HammarKlose (1999, their figure 10).

\begin{tabular}{lc}
\hline \multicolumn{1}{c}{ Rank } & Rate of sea-level rise $(\mathrm{mm} / \mathrm{yr})$ \\
\hline Very low & $<1.8$ \\
Low & $1.8-<2.5$ \\
Moderate & $2.5-<2.95$ \\
High & $2.95-3.16$ \\
Very high & $>3.16$ \\
\hline
\end{tabular}

\section{STORM SURGE (hours to days).}

Image showing areas of the Grand Strand at risk of inundation from hurricanes. Differences in the height of surge from a given storm result from a site's proximity to landfall, geometry of the coastline, and the depth of water offshore. Barrier islands in the northeastern and southwestern parts of the map are at highest risk from category 4 to 5 hurricanes. Mainland-attached beaches in the center near Myrtle Beach maintain relatively high elevations that provide a greater degree of protection. The image was developed by the U.S. Army Corps of Engineers using the Sea Lake and Overland Surges from Hurricanes (SLOSH) model, which was developed by the Federal Emergency Management Agency (FEMA), United States Army Corps of Engineers (USACE), and the National Weather Service (NWS).

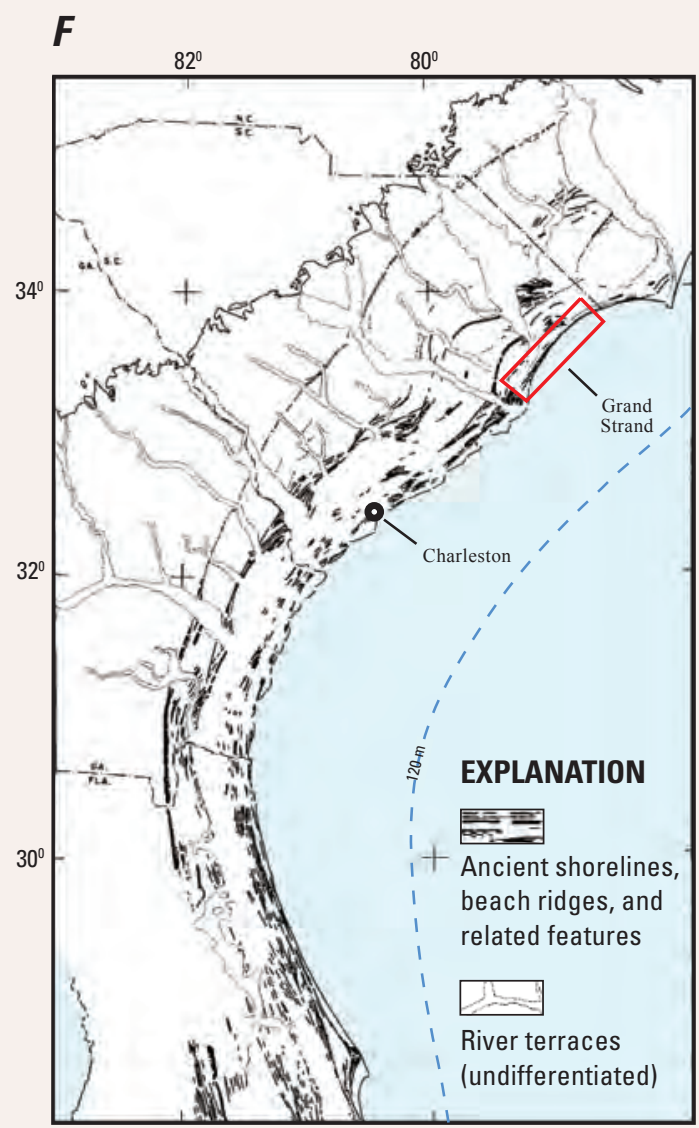

F. SEA-LEVEL CHANGE (thousands of years).

Image of the southeastern United States showing a series of ancient shorelines that formed at previous highstands of sea level. The shoreline deposits are preserved on the middle to lower coastal plain. The 120-m depth contour (dashed blue line) shows the approximate position of the shoreline during the last Ice Age when sea level was lowest relative to today. Little evidence of shorelines marking lower sea levels exists owing to reworking of the continental shelf by terrestrial and marine processes. Figure modified from Winker and Howard (1977, figure 1). 


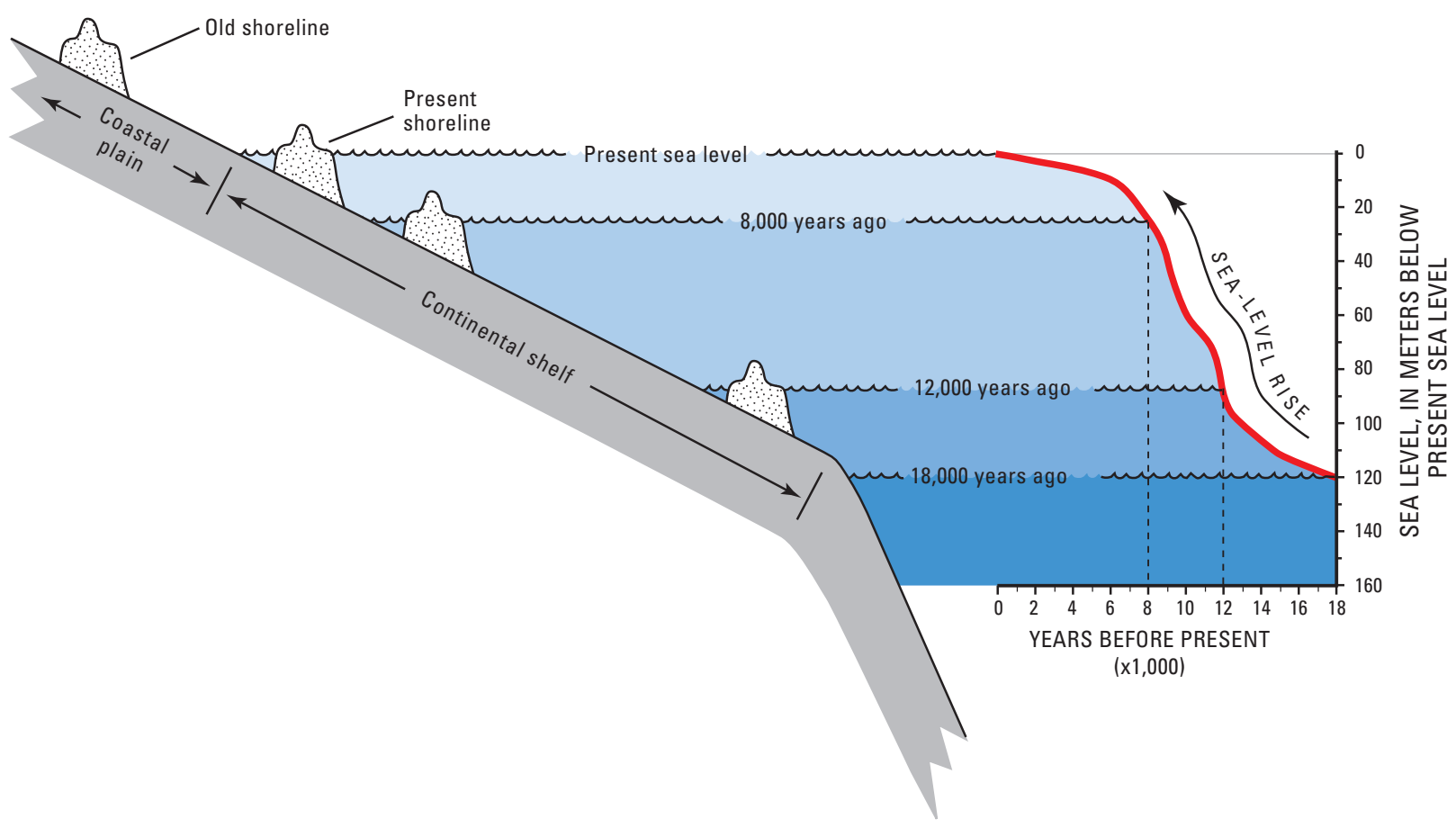

Figure 1.5. Typical response of shorelines to rising sea level. When sea level rises, the ocean advances over the land, and shorelines retreat or move landward. The red line shows the irregular rate of sea-level rise since the end of the last Ice Age (modified from Fairbanks, 1989). At that time, sea level was about $120 \mathrm{~m}$ below the present level, and the shoreline was at or near the edge of the continental shelf. The steep section of the red line between 12,000 and 8,000 years ago shows a rapid sea-level rise that caused shorelines to migrate landward at a faster rate. Even small increases in sea level can cause shorelines to retreat large distances across the gently sloping continental shelf and coastal plain. The rate of sea-level rise slowed about 6,000 years ago and thereby allowed shorelines to stabilize near their present location. Old shoreline deposits on the coastal plain (see figure 1.6) were formed at least 125,000 years ago when sea level was higher than it is today.

currents will erode and redistribute sediment from older deposits along the coast, providing much needed nourishment to the modern beaches of the Grand Strand.

\section{Storms}

Tropical cyclones (tropical storms and hurricanes) and northeasters are the greatest natural hazard facing South Carolina coastal communities. These severe storms generate strong winds and waves, heavy rainfall, and storm surges, which cause extensive erosion, flooding, and damage to infrastructure and development. If storms move slowly or stall at a single location, they might batter a stretch of coastline for several days and wreak great destruction. Historically, South Carolina has experienced direct landfalls of tropical storms and hurricanes relatively infrequently, averaging one every four to five years (see Box \#2). Since 1871, 33 tropical storms and hurricanes have directly hit the state (SCDNR-SCO, 2007). Northeasters, informally called "Nor'easters," are winter storms that affect the South Carolina coastline every year with strong winds that blow in a northeast to southwest direction. These storms can be ten times larger than a hurricane and thereby affect a broader stretch of coast at one time. 


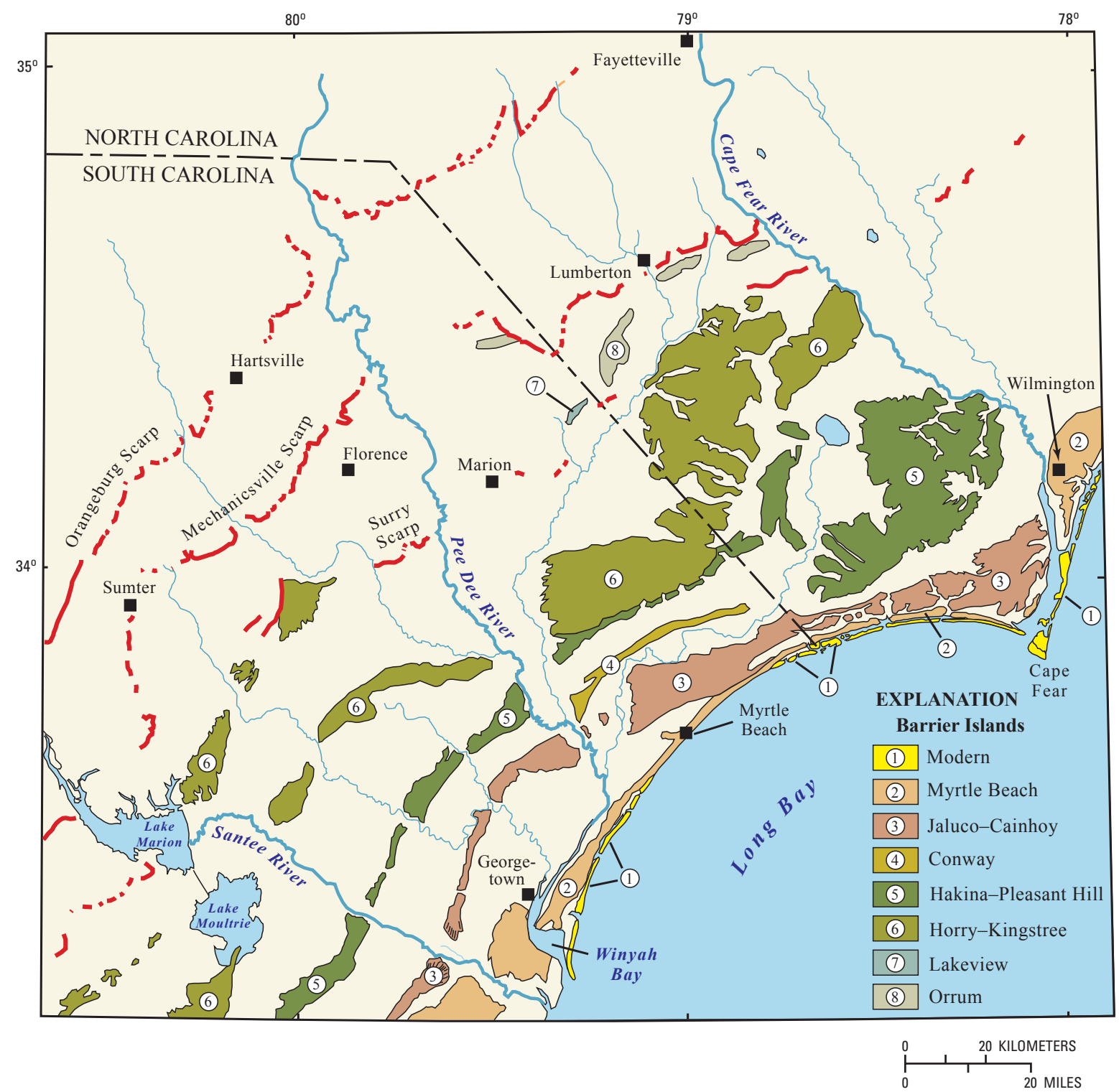

Figure 1.6. Barrier islands and other shoreline features on the coastal plain of the Long Bay region (modified from DuBar and others, 1974). Ancient shorelines (red lines) formed at former highstands of sea level that flooded the coastal plain multiple times over the last 3 to 4 million years. These shorelines step down in elevation and become progressively younger toward the modern coast, with the highest and oldest (Orangeburg Scarp) farthest inland. All the shoreline features have been heavily dissected by rivers and streams. 


\section{BOX \#2: TROPICAL CYCLONES}

Tropical cyclones, which include tropical storms and hurricanes, develop in the tropical and subtropical regions of the North Atlantic Ocean. They begin as tropical depressions, which are low-pressure systems that exhibit cyclonic (counterclockwise) circulation. In the presence of favorable atmospheric conditions, warm tropical waters can provide enough energy to allow these systems to organize and strengthen into more powerful storms. Upper-level winds and pressure systems steer these storms into higher latitudes, where some make landfall and wreak havoc along the coast. Others dissipate over the cooler waters of the North Atlantic.

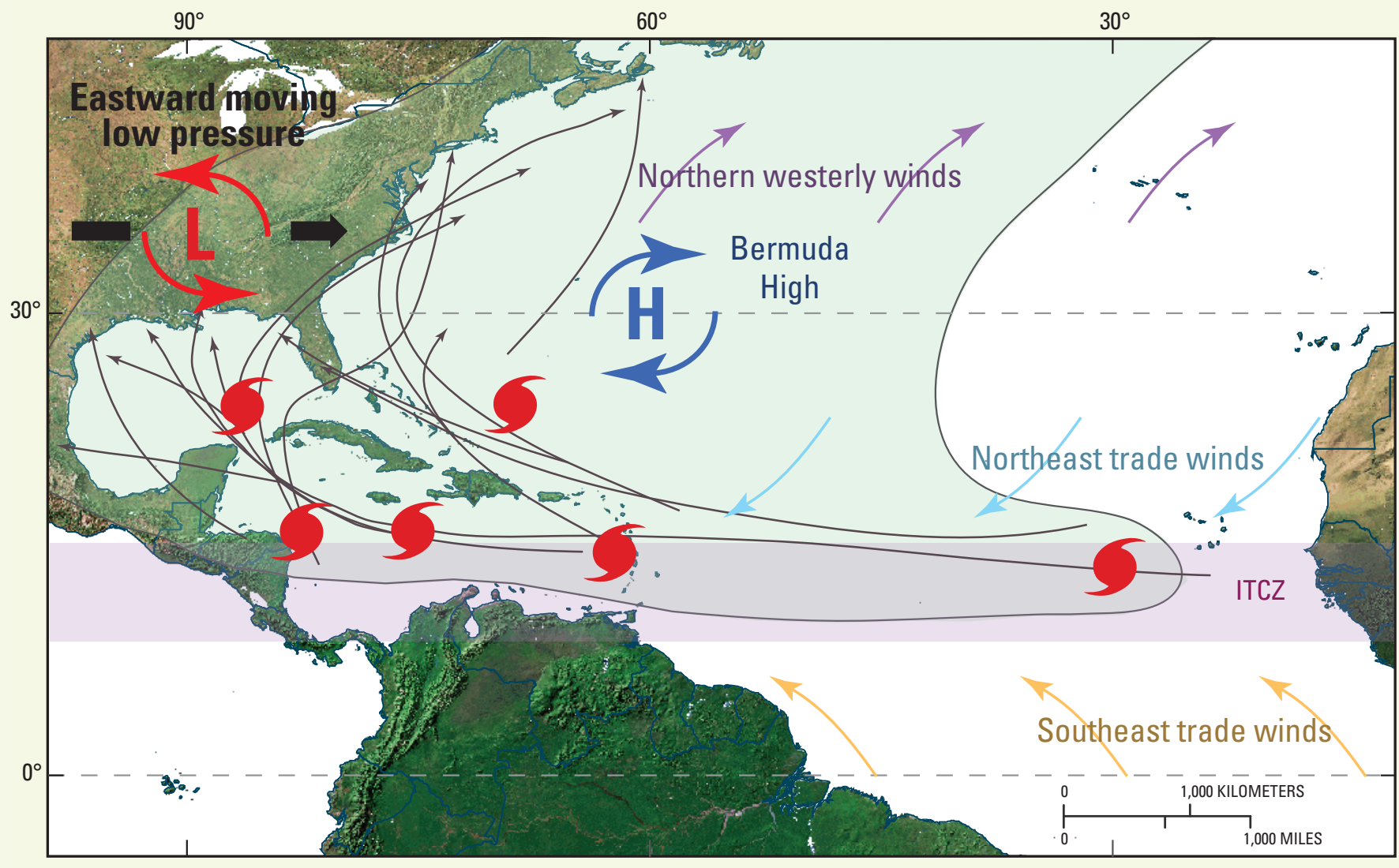

EXPLANATION

Zones of tropicaldepression development
General zone of tropicalstorm and hurricane activity

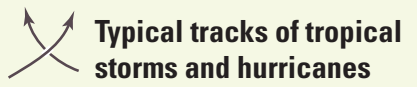
storms and hurricanes
Intertropical Convergence Zone (ITCZ)

Map of the North Atlantic Ocean showing the area of hurricane and tropical-storm activity (light green). Tropical depressions (red symbols) form within or near the Intertropical Convergence Zone (ITCZ, light purple), a zone of low pressure near the equator where trade winds converge and cause moist air to become unstable and rise. Tropical depressions gain strength from warm surface waters and often intensify into tropical storms and hurricanes as they are forced westward by the trade winds and the anticyclonic (clockwise) rotation of the Bermuda High. The storm paths are also influenced by low-pressure systems that move eastward across continental North America, generally causing the storms to recurve and change their heading towards the north and east.

Tropical cyclones occur during a season that extends from June 1 to November 30, with the most activity occurring between July and September. On the basis of the measure of sustained wind speeds near the centers of these storms, they are classified as tropical storms, 63 to $118 \mathrm{~km} / \mathrm{hr}$ (39 to $73 \mathrm{mi} / \mathrm{hr}$ ) or hurricanes, >119 km/hr (74 mi/hr). The Saffir-Simpson Scale (see next page) uses wind speed to further subdivide hurricanes into five categories of intensity and provides descriptions of the storm surge and types of damage that can be expected with each. 
Saffir-Simpson Scale

\begin{tabular}{|c|c|c|c|}
\hline Category & Wind speed & Storm surge ${ }^{1}$ & Potential damage \\
\hline 1 & $\begin{array}{l}74-95 \mathrm{mi} / \mathrm{hr} \\
64-82 \mathrm{kts} \\
119-153 \mathrm{~km} / \mathrm{hr}\end{array}$ & $\begin{array}{l}4-5 \mathrm{ft} \\
1.2-1.5 \mathrm{~m}\end{array}$ & $\begin{array}{l}\text { MINIMAL. Damage primarily to shrubbery, trees, and mobile homes. Low-lying coastal roads } \\
\text { inundated, minor pier damage, small craft torn from moorings. }\end{array}$ \\
\hline 2 & $\begin{array}{l}96-110 \mathrm{mi} / \mathrm{hr} \\
83-95 \mathrm{kts} \\
154-177 \mathrm{~km} / \mathrm{hr}\end{array}$ & $\begin{array}{l}6-8 \mathrm{ft} \\
1.8-2.4 \mathrm{~m}\end{array}$ & $\begin{array}{l}\text { MODERATE. Some trees blown down. Major damage to mobile homes, poorly constructed signs, and } \\
\text { piers. Some damage to building roofs, windows, and doors. Flooding damages piers and marinas. }\end{array}$ \\
\hline 3 & $\begin{array}{l}111-130 \mathrm{mi} / \mathrm{hr} \\
96-113 \mathrm{kts} \\
178-209 \mathrm{~km} / \mathrm{hr}\end{array}$ & $\begin{array}{l}9-12 \mathrm{ft} \\
2.7-3.7 \mathrm{~m}\end{array}$ & $\begin{array}{l}\text { EXTENSIVE. Many large trees and signs blown down. Some structural damage to small } \\
\text { residences and utility buildings. Mobile homes destroyed. Serious flooding, possibly requiring } \\
\text { evacuation of low-lying areas. }\end{array}$ \\
\hline 4 & $\begin{array}{l}131-155 \mathrm{mi} / \mathrm{hr} \\
114-135 \mathrm{kts} \\
210-249 \mathrm{~km} / \mathrm{hr}\end{array}$ & $\begin{array}{l}13-18 \mathrm{ft} \\
4.0-5.5 \mathrm{~m}\end{array}$ & $\begin{array}{l}\text { EXTREME. Extensive damage to small buildings. Complete destruction of mobile homes. Major } \\
\text { erosion of beaches. Flooding far inland, possibly requiring evacuation of areas near the shore. }\end{array}$ \\
\hline 5 & $\begin{array}{l}>155 \mathrm{mi} / \mathrm{hr} \\
>135 \mathrm{kts} \\
>249 \mathrm{~km} / \mathrm{hr}\end{array}$ & $\begin{array}{l}>18 \mathrm{ft} \\
>5.6 \mathrm{~m}\end{array}$ & $\begin{array}{l}\text { CATASTROPHIC. Considerable damage to residences and industrial buildings; some complete } \\
\text { structural failures. Extensive flooding possibly requiring evacuation within } 5 \text { to } 10 \text { miles } \\
\text { (8 to } 16 \mathrm{~km} \text { ) of shore. }\end{array}$ \\
\hline
\end{tabular}

${ }^{1}$ Storm-surge values are highly dependent on the slope of the continental shelf and the shape of the coastline.

${ }^{2}$ kts, knots (1 knot $=1.15$ miles per hour).

In September 1989, Hurricane Hugo slammed into the South Carolina coast near Charleston as a strong category-4 storm. Large waves severely eroded beaches and dunes in several southeastern States. A maximum storm surge of $6 \mathrm{~m}$ ( $20 \mathrm{ft}$ ) completely submerged some low-lying barrier islands north of Charleston. At the time, Hugo was the costliest hurricane to ever hit the U.S. mainland. It remained at category- 1 strength all the way to Charlotte, N.C., about $300 \mathrm{~km}(180 \mathrm{mi})$ inland from the coast, and destroyed many homes, trees, and farms. In South Carolina alone, 29 people were killed, and property damages were estimated at $\$ 6$ billion.

Hurricane Hugo was only one of many hurricanes to impact the South Carolina coast during historical time. From 1871 to 2008, a total of 33 tropical storms and hurricanes made direct hits on the State, including six major hurricanes of category 3 or higher.

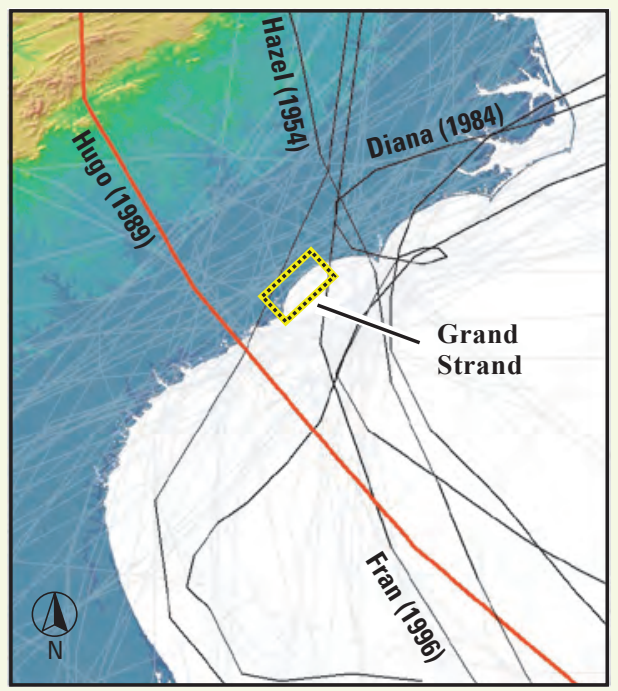
Hurricane Center.

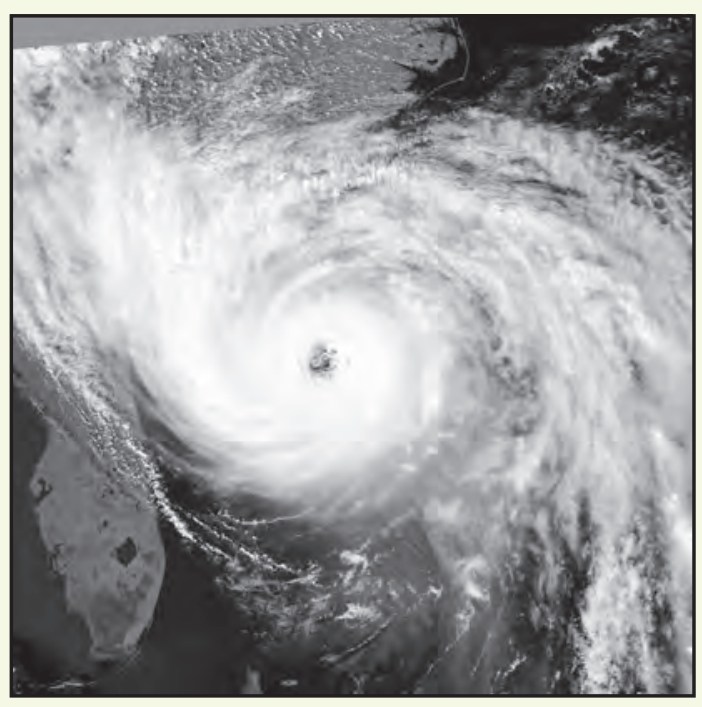

Satellite image of Hurricane Hugo on September 21, 1989, just hours before making landfall on the South Carolina coast. Source: NOAA National Hurricane Center.

Image of hurricane tracks that hit or passed near the South Carolina coast from 1851 to 2005. Thin gray lines indicate tropical storms and minor hurricanes (categories 1-2). Black lines indicate major hurricanes (categories 3-5). Red line indicates Hurricane Hugo. Source: NOAA National

Additional reading:

Brennan, J.W., 2001, Meteorological summary of Hurricane Hugo: Journal of Coastal Research, Special Issue 8, p. 1-12. 
Strong winds associated with storms accentuate high tides by piling ocean water along the coast and not allowing it to recede during a subsequent low tide. If this situation persists over multiple tidal cycles, extreme coastal flooding results. Such storms do not need to make direct landfall in order to affect the coastline significantly. Whether they make landfall elsewhere and pass through the state or pass close to the coast offshore, they can still produce violent winds, waves, and storm surge. Storms that pass farther offshore might actually be beneficial by generating long-period swells that move sandy sediment towards Grand Strand beaches.

\subsection{Beachfront Management}

Prior to 1988, regulation of development along the coast of South Carolina was limited, and seawalls were routinely permitted on beaches. Most hard stabilization structures (fig. 1.7) were emplaced during the late 1970s and 1980s under the guidelines of the South Carolina Coastal Zone Management Act. This legislation established the Critical Line as a benchmark from which to regulate oceanfront development. The line was defined as either the scarp line or the seaward toe of the primary dune. The State had no jurisdiction to regulate development in areas landward of the line. Much of the new oceanfront construction during this period was placed too close to the coast and thus was at immediate risk of damage by storms.

Recognizing that the existing laws had failed to preserve the integrity of the beach/dune system, the State legislature passed the South Carolina Beachfront Management Act (SCBMA) in 1988 (see Box \#3). With further amendments added in 1990, this legislation improved coastal management in two important ways. First, it mandated the Office of Ocean and Coastal Resource Management (OCRM) to regulate coastal development activities on a statewide basis. Second, it largely prohibited seawalls and promoted use of soft erosion-management solutions such as beach nourishment. Every ten years, the statewide base line is updated to account for shoreline changes over that time period. South Carolina's beaches are monitored by OCRM, which publishes assessments entitled "State of the Beach" in annual reports (SCDHEC-OCRM, 1995-2006). Because most of the State's coast is eroding, the base line moves landward in step with the retreating shoreline. In this way, properties originally located landward of the base line can fall under the jurisdiction of the SCBMA.

Whereas many agree with the long-term objective of beach management, application in the short term has proven difficult. The State's beachfrontmanagement policy has been challenged, and one case (Lucas v. South Carolina Coastal Council) was ultimately considered by the U.S. Supreme Court. Regardless of legal outcomes, the shoreline continues to move, and the migration brings coastal infrastructure into conflict with the relentless natural processes that shape beaches. The inevitable result of the policy, when viewed in the context of the State's chronically eroding beaches, is one of retreat from the coast. South Carolina has effectively chosen to retreat but struggles to accomplish this feat and, at the same time, solve the significant economic problems that the strategy creates.

As in many coastal states, beach nourishment has been the predominant strategy for slowing the effects of coastal erosion and thereby delaying implementation of long-term policies. After Hurricane Hugo struck in 1989, the City of Myrtle Beach began an expensive program to renourish its beaches with sand trucked from inland borrow pits. By the mid1990s, the demand for sand had increased, and the city opted for mining offshore sources to maintain the beaches. Identification of additional sand sources in offshore areas has become a priority issue to supply future nourishment projects, which are projected to be repeated every 8 to 10 years along the Grand Strand.

\subsection{South Carolina Coastal Erosion Study}

The USGS Coastal and Marine Geology Program and the SCSGC began scientific investigations of coastal erosion along the Grand Strand in 1999. The South Carolina Coastal Erosion Study (SCCES) is one of the most comprehensive regional studies undertaken to date and has provided critical information for management of the State's coastal resources. The cooperative effort involves the USGS Coastal and Marine Geology Program, Coastal Carolina University, University of South Carolina, College of Charleston, Georgia Institute of Technology, Scripps Institution of Oceanography, and South Carolina Sea Grant. 

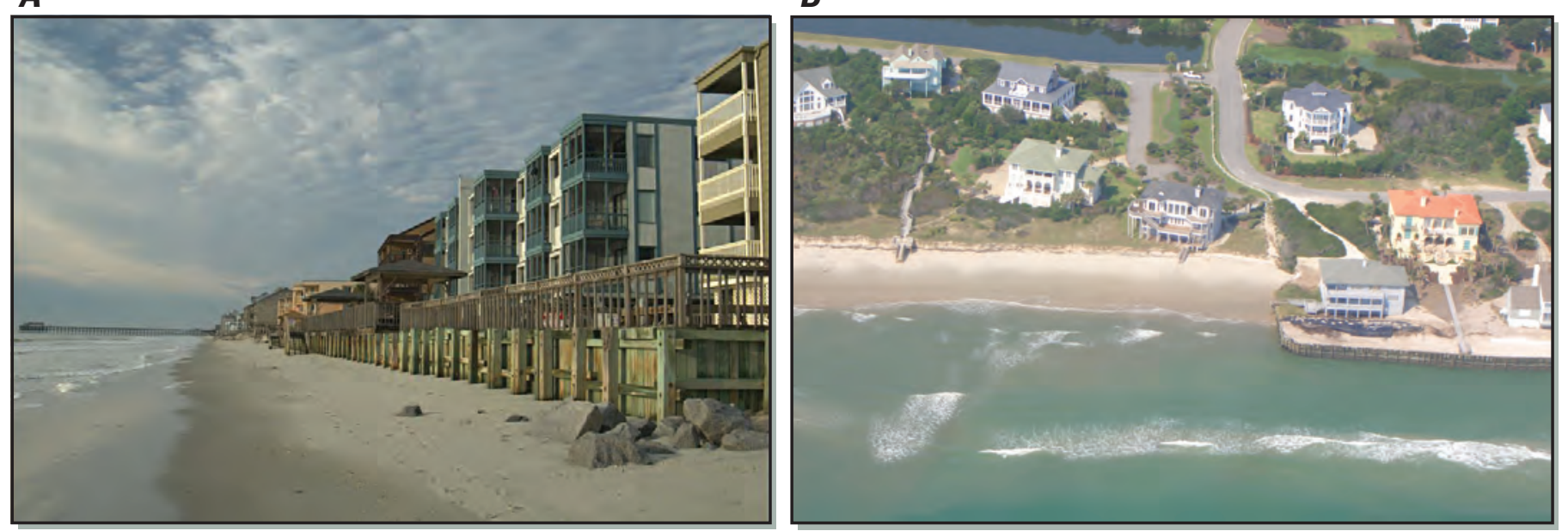

Figure 1.7. Effects of engineering structures on South Carolina's beaches: (A) Seawall at Garden City Beach in February 2007; see figure 1.3B for location. Seawalls are constructed to protect structures from being undermined as the shoreline migrates landward. This image highlights the dilemma between saving structures and maintaining a usable beach. Published by permission of M. Scott Harris, College of Charleston, Charleston, South Carolina. (B) Southern end of the seawall at Debordieu Island in June 2005; see figure 3.2 for location. The adjacent unarmored section of coast is left free to migrate and leaves the seawall-protected property in a precarious position seaward of the natural shoreline. Beach nourishment has been used at this site to prevent failure of the seawall and temporarily provide some beach function. Published by permission of Paul Gayes, Coastal Carolina University, Conway, South Carolina.

The SCCES attempts to understand the full range of factors and processes that control sediment transport and coastal morphology along the Grand Strand. Knowledge of how the coastal system functions enhances our ability to predict coastal change ranging from the short-term effects of a single storm (hours to days) to the long-term effects of sea-level rise (decades to centuries). The interdisciplinary nature of the study has required cooperation among geologists, geophysicists, physical oceanographers, and numerical modelers. Our systematic approach consists of three phases:

1. Describe the regional geologic framework, which refers to the structure, composition, and distribution of rocks and sediment that compose the coast, shoreface, and inner continental shelf.
2. Determine seasonal and longer term patterns of shoreline change by surveying beaches at regular intervals over several years.

3. Quantify the physical processes that drive coastal erosion through a combination of field measurements and numerical-modeling simulations.

This report synthesizes the geologic and oceanographic factors that control sediment movement along the Grand Strand inner shelf and beaches. Ultimately, the three-part research strategy applied in this study will improve the prediction of shoreline behavior and guide efforts in other regions where limited sediment availability on the inner shelf is linked to coastal erosion. 


\section{BOX \#3: LINES IN THE SAND}

The South Carolina Beachfront Management Act (SCBMA) is designed to protect coastal resources while also promoting responsible development in the State's coastal zone. The SCBMA was adopted in 1988 and established a jurisdictional base line typically placed at the crest of the primary dune, if present. The SCBMA called for developers to locate new construction at a minimum distance landward of the base line. This minimum distance, delineated by the setback line, is established where the base line is calculated to be in 40 years (that is, a distance equal to 40 times the annual erosion rate). The annual erosion rate is determined from analysis of aerial photographs and beach profiles. Because the rate of erosion varies along the coast, the distance to the setback line is not the same for every section of beach. Also under the SCBMA, no new seawall construction is allowed, but older erosion-control structures can be maintained. If an existing structure is heavily damaged or destroyed, however, it must be removed by the owner. Specific provisions include:

- No construction is allowed seaward of the base line. The law was amended in 1990 and again in 2002 to allow for special permits on a case-by-case basis. The special permits, if issued, strictly limit the size and design of new construction.

- Development is heavily regulated between the base line and the setback line. If an existing property in this area is damaged beyond 50 percent, it cannot be rebuilt.

Inlet systems locally complicate pathways of sand movement, and beaches adjacent to inlets are particularly dynamic. As a result, the SCBMA classified sections of the coast as "standard zones" and "inlet hazard zones" (see examples below). Standard zones are those areas away from the influence of inlets; these zones are defined by having shore-parallel depth contours. In standard zones, the base line is defined as the crest of the primary dune identified by beach surveys. Inlet hazard zones are those areas adjacent to tidal inlets where depth contours are oblique to the coast due to the influence of inlet-associated shoals and nearshore sand bars. In inlet hazard zones, the base line is defined by the most landward position of the shoreline in the previous 40 years as identified from aerial photographs.
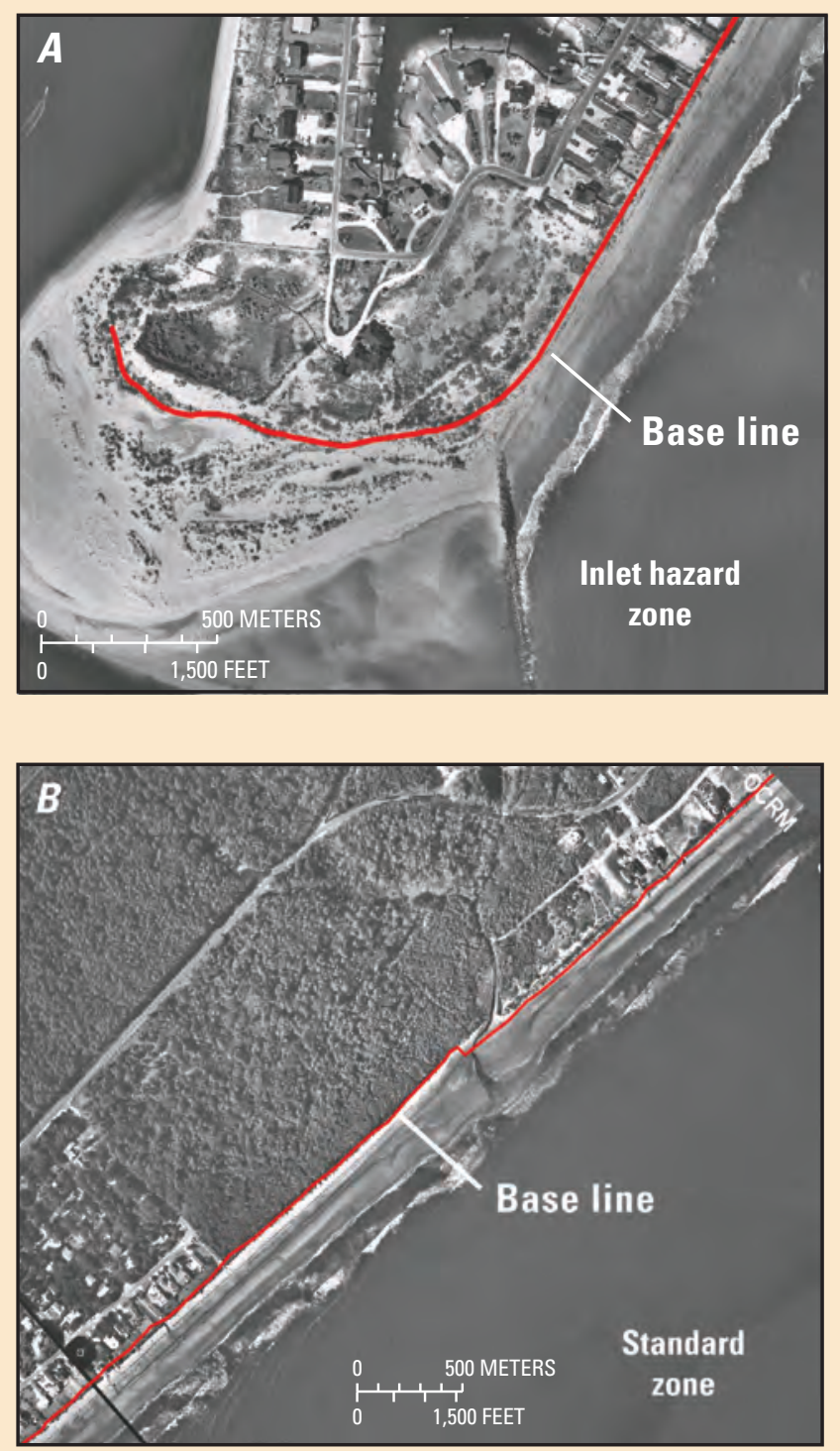

Aerial photographs showing examples of the jurisdictional base line (red line) established in 2000. (A) Inlet hazard zone in Garden City, South Carolina. The base line in this area is defined by the landward-most erosion of vegetation as seen on aerial photography over the last 40 years. (B) Standard zone in Myrtle Beach, South Carolina. The base line in this area is defined by the crest of the primary dunes as determined by beach-profiling surveys.

The SCBMA also recognized that engineering structures, where they exist, strongly modify beach processes and behavior. As a result, standard zones are further divided into "natural" and "armored" areas. For armored areas, the primary dune crest no longer exists as a marker to determine the base line. Instead, an idealized-dune crest is projected landward of the shore-protection structure on an equivalent-volume basis (see example below). Inlet hazard zones are similarly divided into "stabilized" and "unstabilized" areas. In the vicinity of jetties and other structures, profiles from adjacent nonengineered beaches are used to project the base line along the coast. 
C

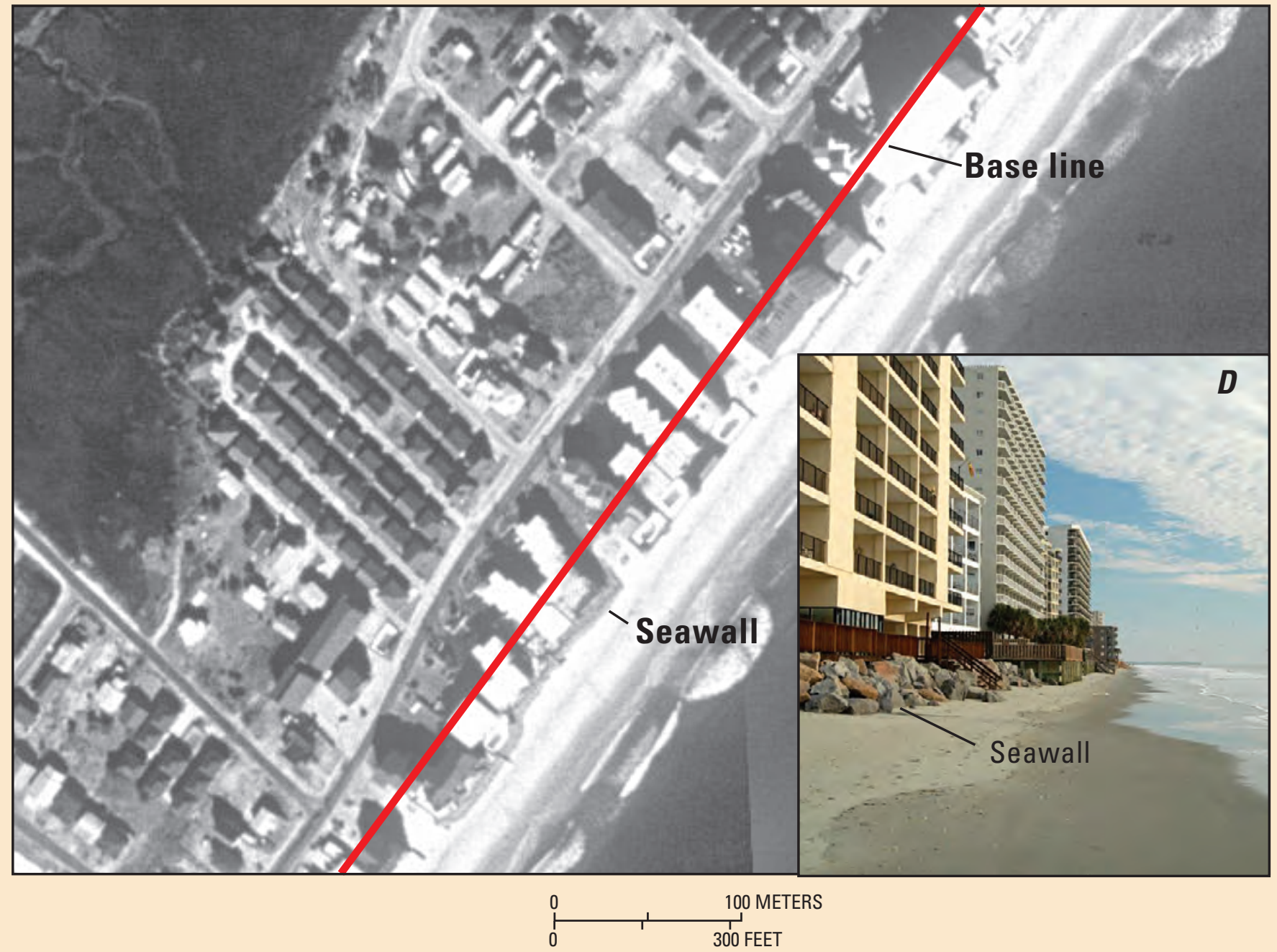

Aerial photograph (C) of high-rise buildings along the beach at Garden City, South Carolina. The base line (red line) runs through the structures which are very close to the beach and fronted by a seawall (D) and would not meet present development standards. No dune crest exists, so the location of the base line is determined by fitting an undisturbed-beach profile $(E$, dashed line) to the existing armored-beach profile $(E$, solid line) so that there is an equivalent sand volume between the two profiles. The base line is set at the idealized-dune crest, which is landward of the seawall.

\section{$\boldsymbol{E}$}

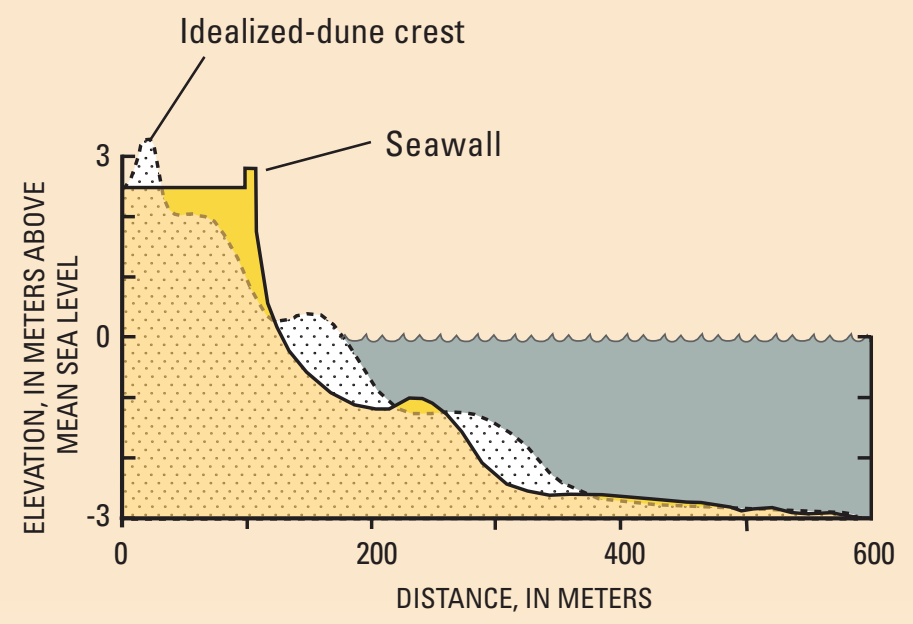




\subsection{Introduction}

$\sim$ cientists within the USGS Coastal and Marine $\checkmark$ Geology Program conduct research and mapping investigations designed to understand fundamental processes that create, modify, and maintain coastal and nearshore marine systems. The following sections describe methods used by the SCCES to map the geologic framework, assess historic shoreline change, and define the modern oceanographic processes influencing sediment transport along the coast of northeastern South Carolina.

\subsection{Mapping the Geologic Framework}

The geologic framework forms the foundation of the coastal system and is shaped by the cumulative effects of tectonics, storms, sea-level change, and human activities. The geologic framework is defined by identifying three primary components: (1) seafloor topography (bathymetry), (2) texture and distribution of sediment on the seafloor, and (3) structure and composition of older rocks and sediment that underlie the seafloor, beach, and lower coastal plain. To map these components, a suite of remote-sensing and sampling techniques are employed both at sea and on land (figs. 2.1, 2.2A and B).

To see beneath the ocean surface and image seafloor environments, sound (acoustics) energy is used. Sound travels efficiently in water and can penetrate deep into the ocean to provide detailed views of the seafloor; these views are comparable to topographic maps or aerial photographs on land. During the SCCES, different types of sonar systems were deployed that bounce sound waves off the seafloor and underlying rocks and sediment (fig. 2.1). Return signals, or reflections, are measured by the sonar systems and are used to produce sound images of the seafloor terrain and subsurface geology.

\section{Seafloor Topography}

Swath-bathymetric systems measure water depth in a narrow band, or swath, perpendicular to the direction of ship travel (fig. 2.1). The systems emit a series of acoustic pulses that insonify the seafloor beneath the survey vessel and scatter sound in many directions. Some sound energy is reflected back to the sonar and precisely recorded. The angle, intensity, and traveltime of these reflected signals are used to calculate water depth along the swath. As the vessel moves forward, continuous depth measurements are collected and used to generate detailed bathymetric maps of the seafloor (fig. 2.3).

\section{Surficial Geology}

Sidescan or side-looking sonar systems are used to image wide areas (tens of meters to kilometers) of the seafloor (fig. 2.1). These systems emit a series of acoustic pulses, or pings, that insonify the seafloor along a ribbon-like swath perpendicular to the direction of travel. Sound scatters in all directions as it intersects the seafloor, with some percentage reflected back to the sonar. The traveltime and intensity of these reflections are recorded, and their relative intensity (backscatter) provides information about the type of material that covers the seafloor. As the research vessel moves forward, continuous pings insonify a swath along the seafloor much as a lawnmower cuts through grass. To obtain full coverage of the bottom, the ship sails back and forth as though it were mowing the lawn along a closely spaced series of parallel tracklines, with each swath overlapping adjacent swaths. Finally, the data are stitched together to form a composite sidescan-sonar image (figs. 2.4 and 2.5).

\section{Subsurface Geology}

Subbottom-profiling systems are used to image the internal structure of the seafloor (fig. 2.1). Similar to swath bathymetric and sidescan-sonar systems, subbottom profilers emit pulses of sound and then measure the intensity and traveltime of the return signals. In this case, however, more power is used to generate an acoustic pulse that penetrates into the subsurface and travels through rock and sediment. When the acoustic pulse moves across a boundary marking a contrast in physical properties, such as the upper surface of rocks buried beneath a sheet of sand or internal layering within individual deposits (fig. 2.6), some of the sound energy is reflected back to surface receivers and recorded. 


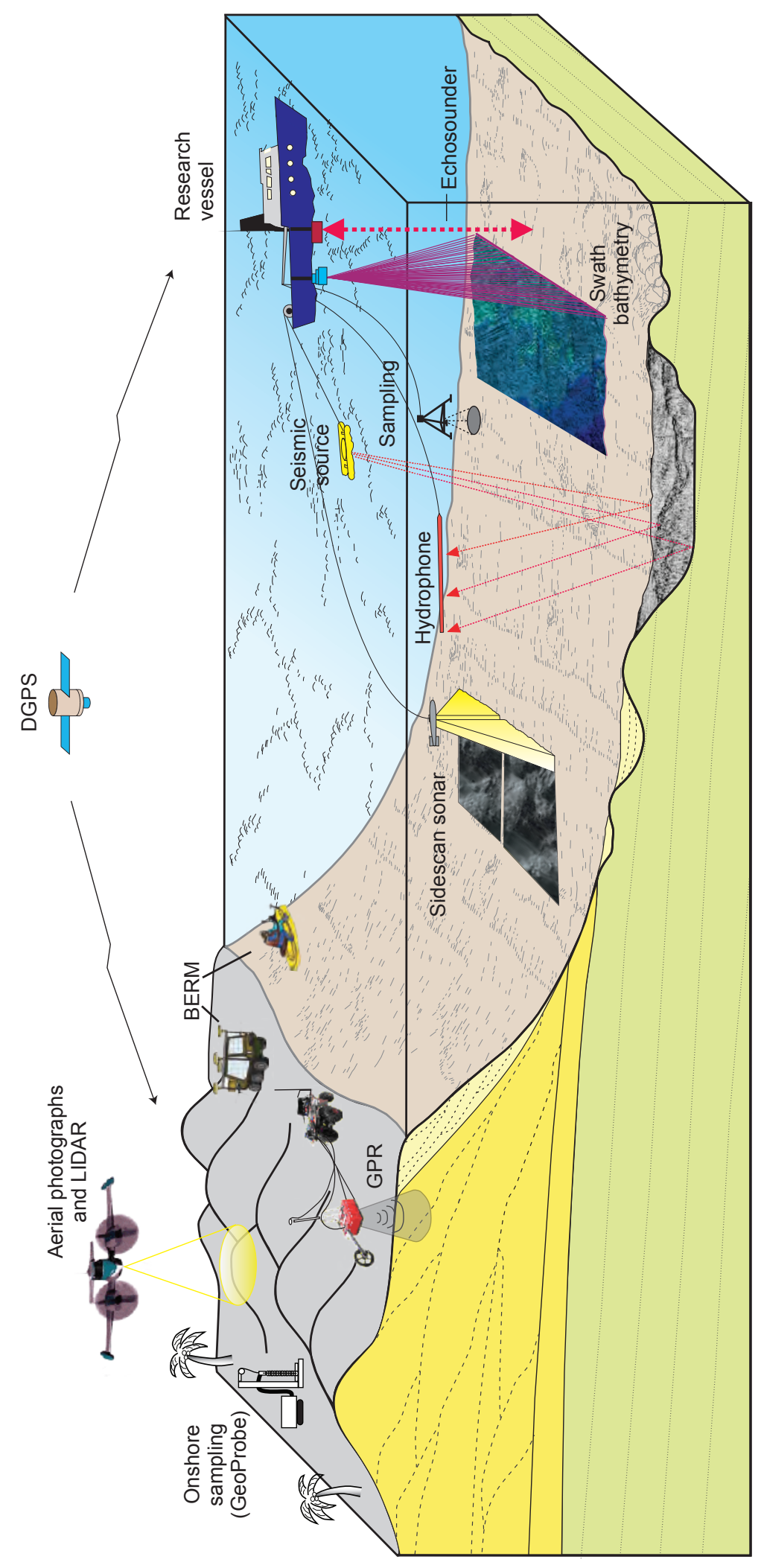

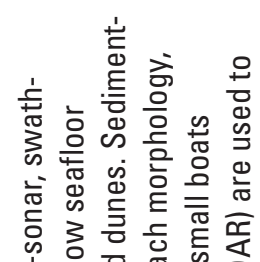

衣응

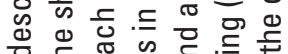

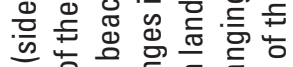

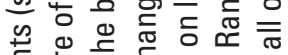

总

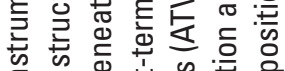

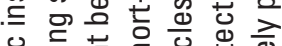

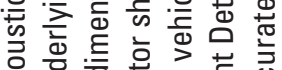

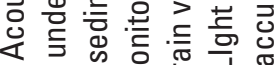

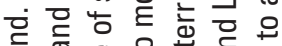

匹

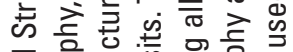

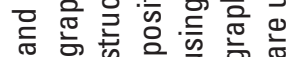

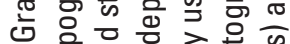

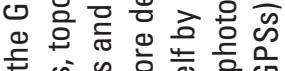

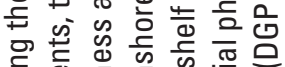

흠

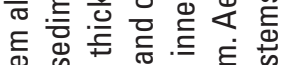

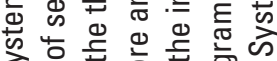

के ᄃ

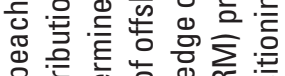

远语

券造它出出

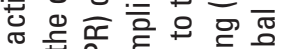

항

Ð

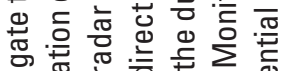

号苋

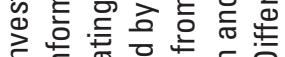

든

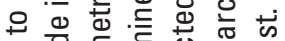

垴

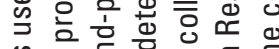

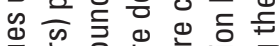

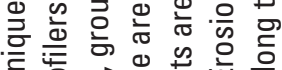

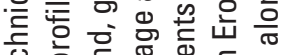

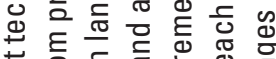

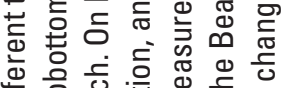

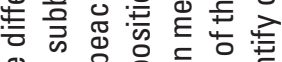

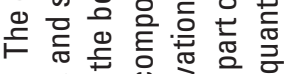

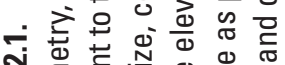

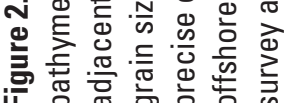


$\boldsymbol{A}$

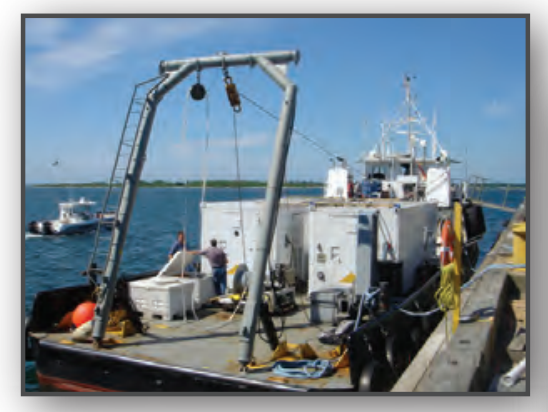

C

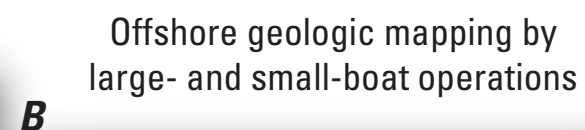

$B$

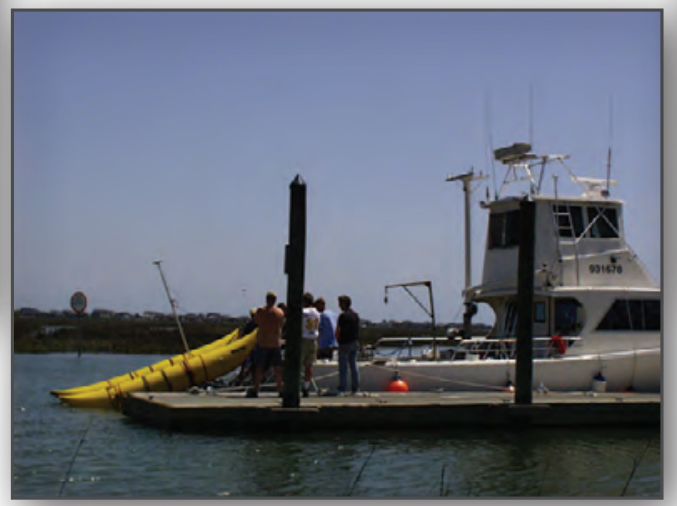

D
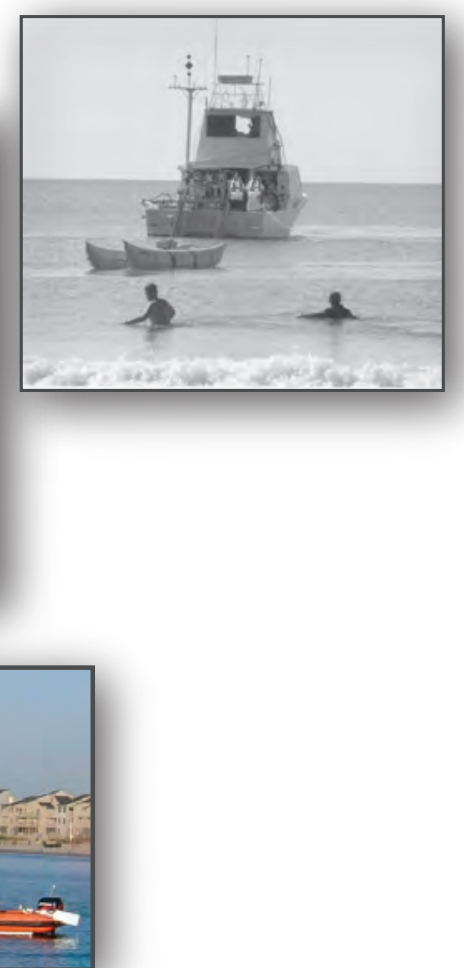

$\boldsymbol{E}$

Geologic-mapping techniques

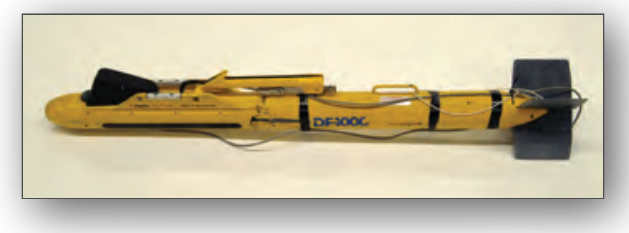

$\boldsymbol{F}$

G

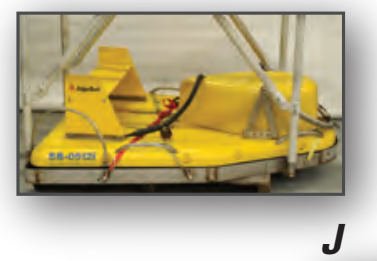

$J$
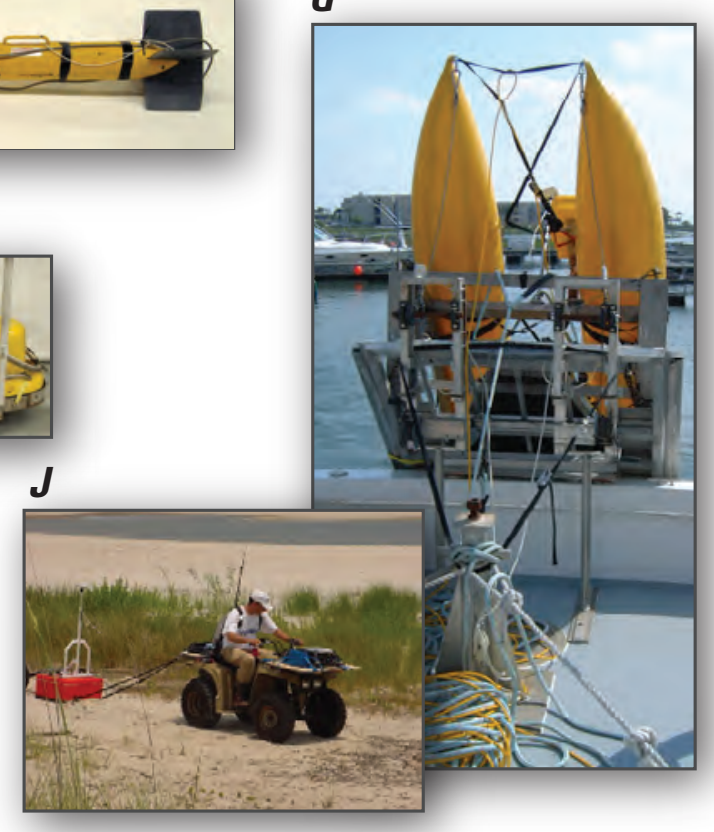

$\boldsymbol{H}$

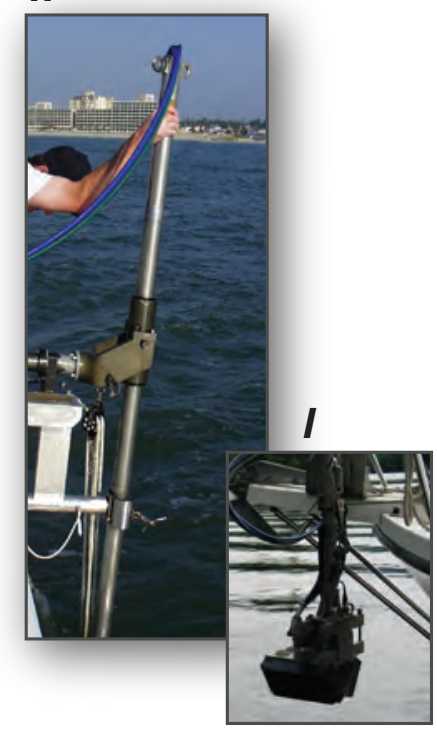

Figure 2.2A. Mapping operations of the SCCES include $(A)$ research vessel at dock preparing for departure, $(B)$ small research vessel at dock with subbottom profiler towed from the stern, $(C)$ subbottom profiler towed by rigid-hull inflatable boat directly off the beach, (D) subbottom profiler towed in very shallow water away from the beach, (E) sidescan-sonar system, (F) subbottom profiler, (G) subbottom profiler deployed off the stern of small coastal research vessel, $(\mathrm{H})$ swath-bathymetric system configured as a side mount, (I) swathbathymetric transducer deployed off the bow of a small vessel, and (J) all-terrain vehicle (ATV) towing a ground-penetrating radar sled across the beach. 
Onshore and offshore sampling techniques

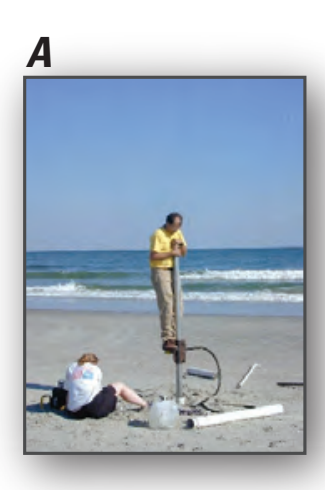

B

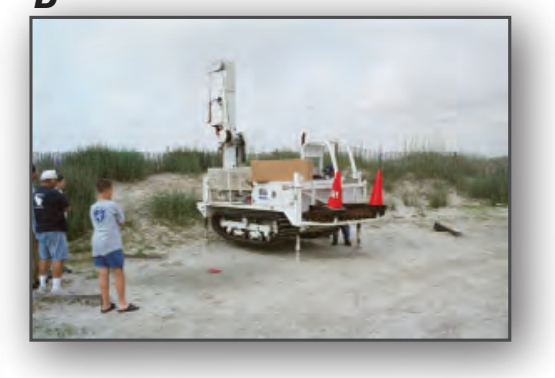

D1

D2

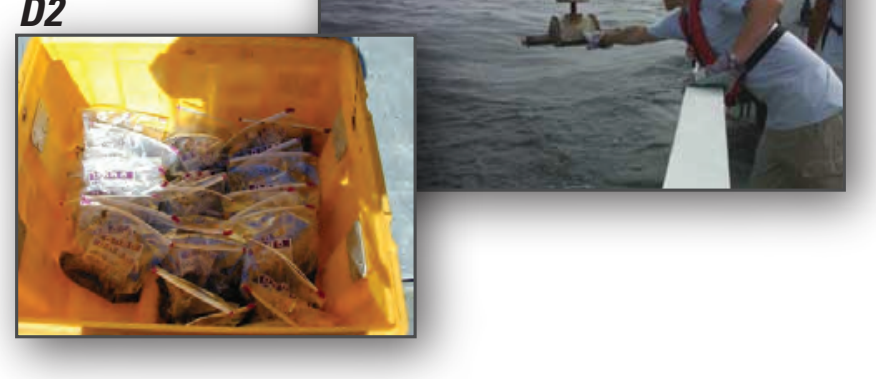

F1 Measuring shoreline change

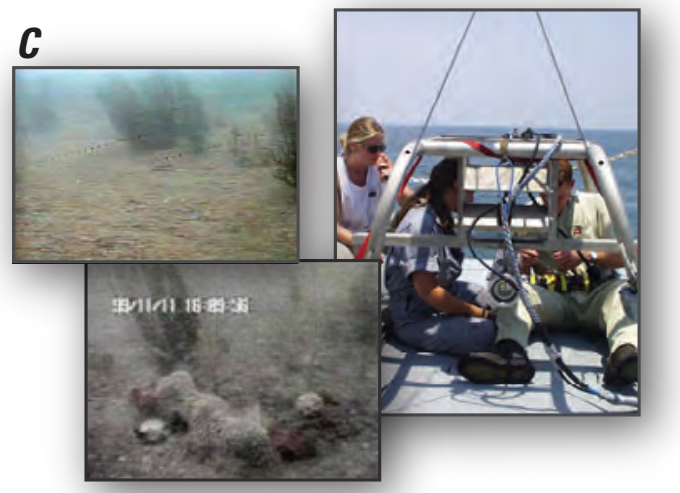

E1

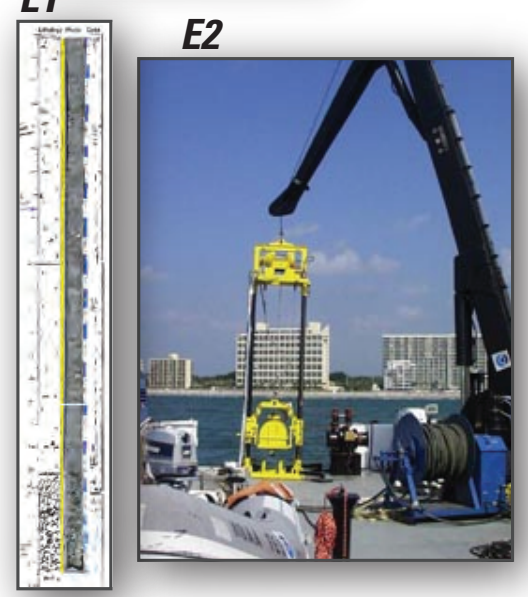

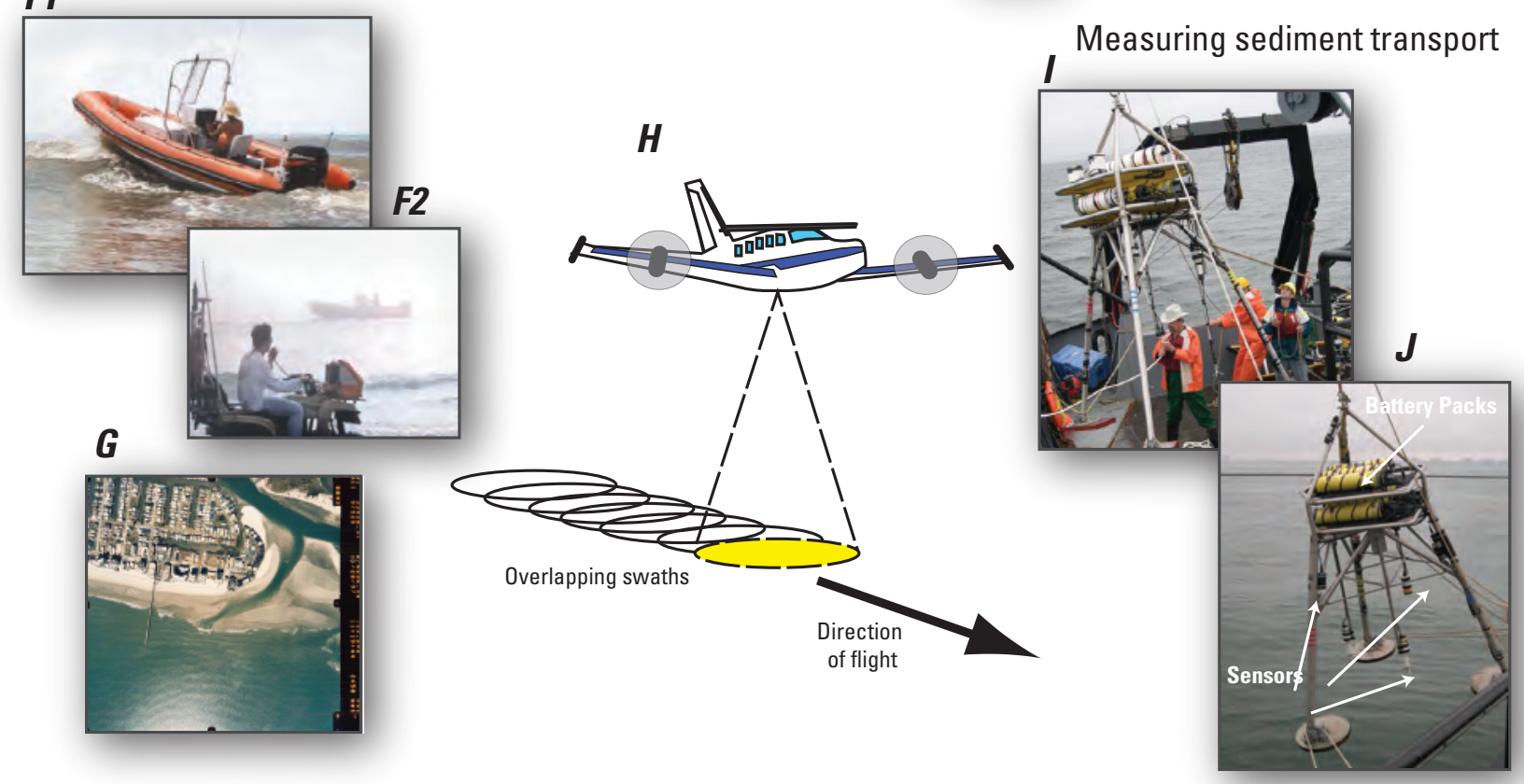

Figure 2.2B. Mapping operations of the SCCES include $(A)$ collection of sediment core on the beach, $(B)$ large coring rig for deep sampling, (C) video camera used to collect images of the seafloor, (D1) grab sampler used to collect sediment from the seafloor, (D2) sediment samples stored in bags for laboratory analysis, (E1) photograph of a sediment core, (E2) collection of offshore sediment with Vibracores, (F1) rigidhull inflatable boat measuring beach profiles in nearshore area, (F2) ATV measuring beach profiles onshore, $(G)$ aerial photograph used in shoreline-change analysis of North Myrtle Beach, (H) LIDAR systems rapidly map topography over extensive areas of coast, and (I) and (J) deployment of oceanographic instruments on a tripod (rigid three-leg structure) that will be anchored to the seafloor. 

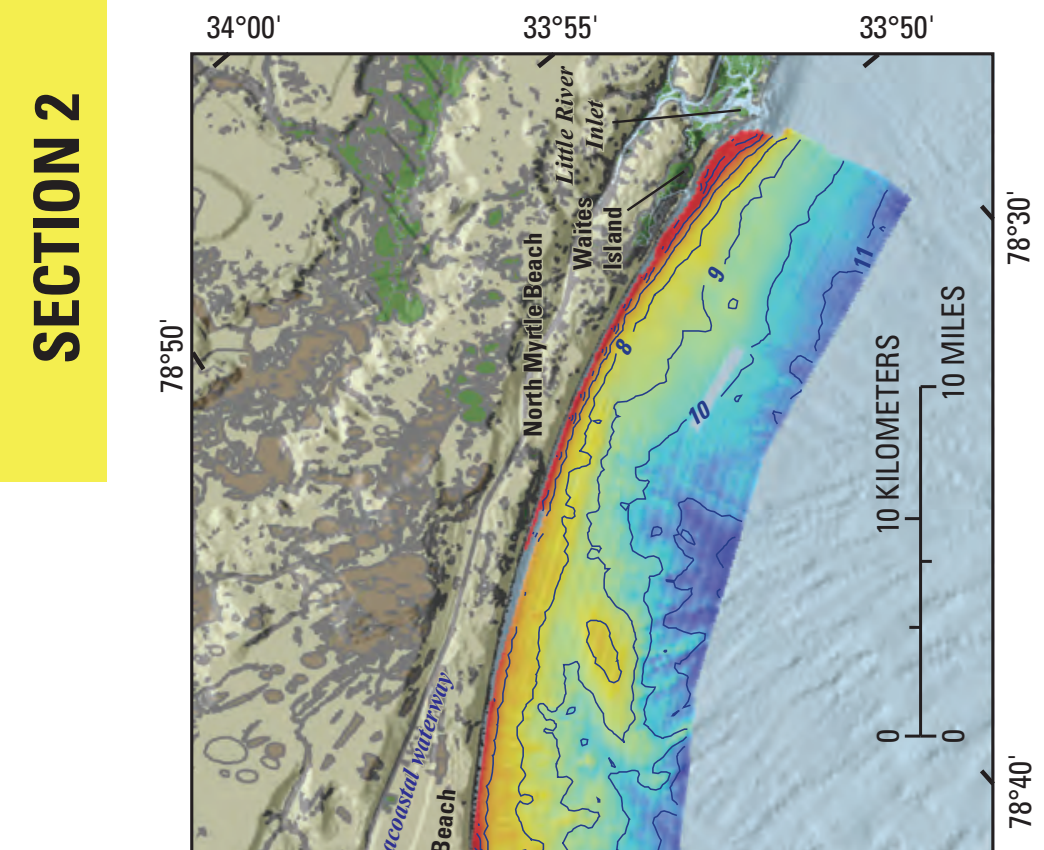

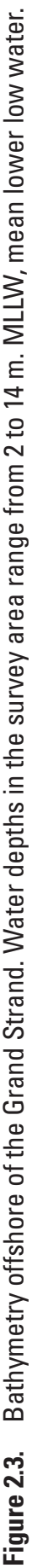




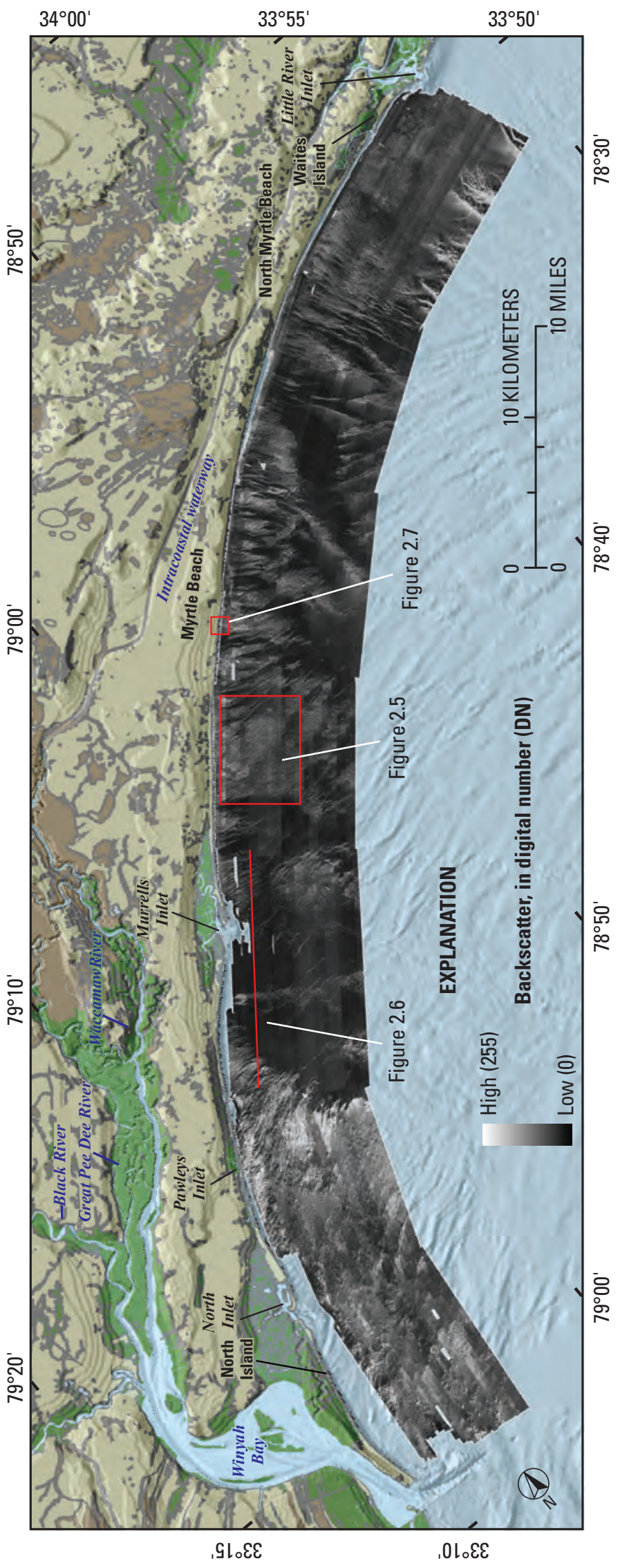

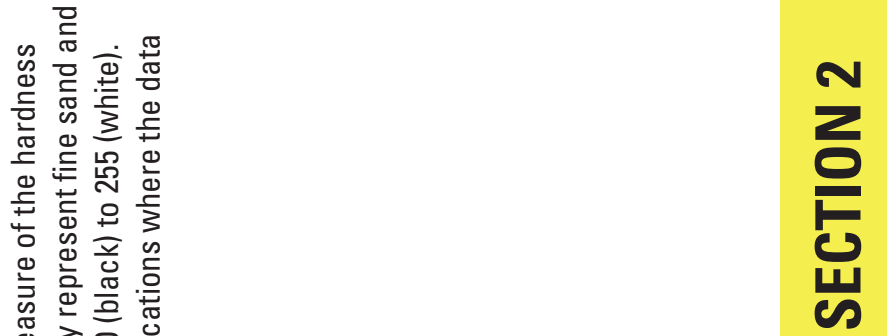

远

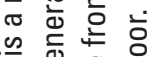

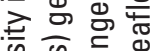

¿ స

总 등 음

产市 交

兽 心

西 赤

㐫 ฏ.

잏ํ क

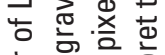

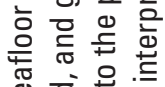

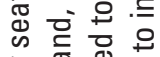

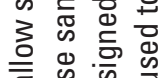

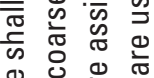

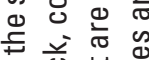

등 흔

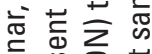

क ⿻ ㇒𠃋 든

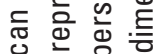

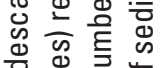

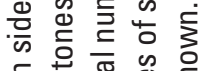

声志焉出

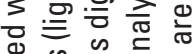

造造

đั

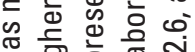

글 흥흐 닝

亦充

व

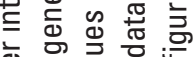

过 焉

顿

은 은 윰

西

.

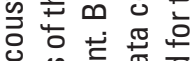

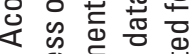

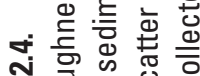

。

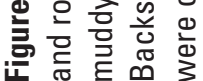




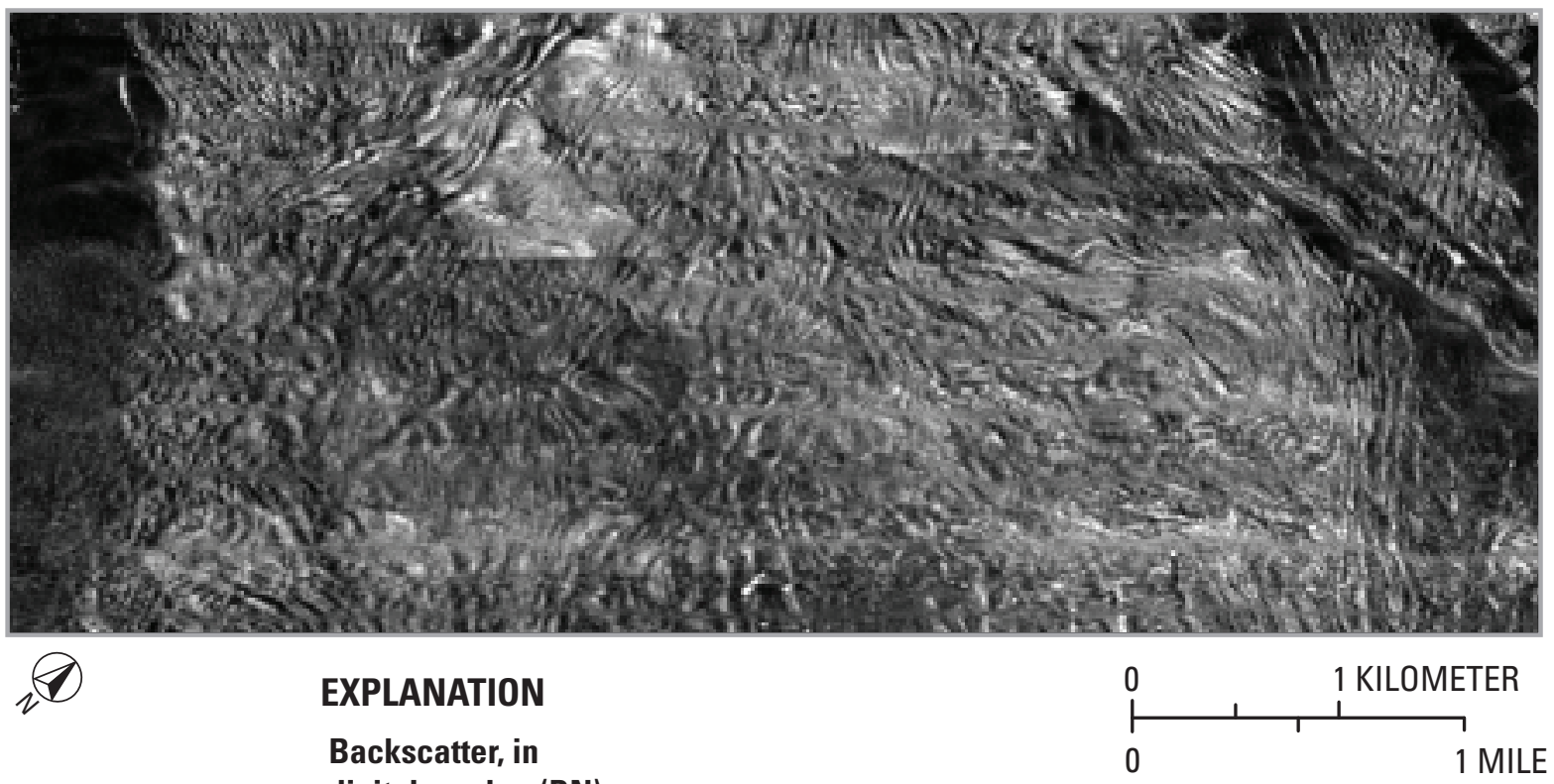
digital number (DN)

High (255)

$\operatorname{Low}(0)$

Figure 2.5. Enlarged section of the sidescan-sonar image in figure 2.4 shows the complexities of the shallow seafloor offshore of Myrtle Beach (location shown in figure 1.3B). Intricate patterns of high backscatter (light tones) and low backscatter (dark tones) represent exposures of rock and fine-sand deposits, respectively. Backscatter values are represented as digital numbers (DN) that are assigned to the pixels within the imagery and range from 0 (black) to 255 (white). See figure 2.4 for location of section.

Ground-penetrating radar (GPR) is used to image the subsurface geology beneath the beach and other land areas. Instead of sound energy, GPR emits pulses of FM-frequency radio waves from an antenna traveling across the ground surface (fig. 2.1). When the outgoing signal travels across boundaries marking a change in the physical and chemical properties of the underlying deposits, some energy is reflected back to the surface. As with subbottom profiling, the time it takes a signal to travel from the antenna into the ground and back is precisely measured and converted to distance. Numerous closely spaced soundings are combined to form an image of the subsurface and used to measure the thickness of beach sand over rock, for example, or to locate buried channels formed by ancient streams or tidal inlets (fig. 2.7).

\section{Seafloor Sediment}

The geophysical techniques described above allow us to see through ocean waters and deep below the land surface to image the surficial and subsurface geology; however, it is difficult to determine the physical characteristics, such as grain size, of seafloor sediment and subsurface deposits on the sole basis of these remote images. In order to fully understand what the imagery represents, we need to collect physical samples of rocks and sediment and analyze them in the laboratory. A variety of techniques, such as coring and grab sampling, are used to sample sediment deposits (fig. 2.2B). Additional techniques, such as photography and video, are also used to verify interpretations of seafloor geology. 


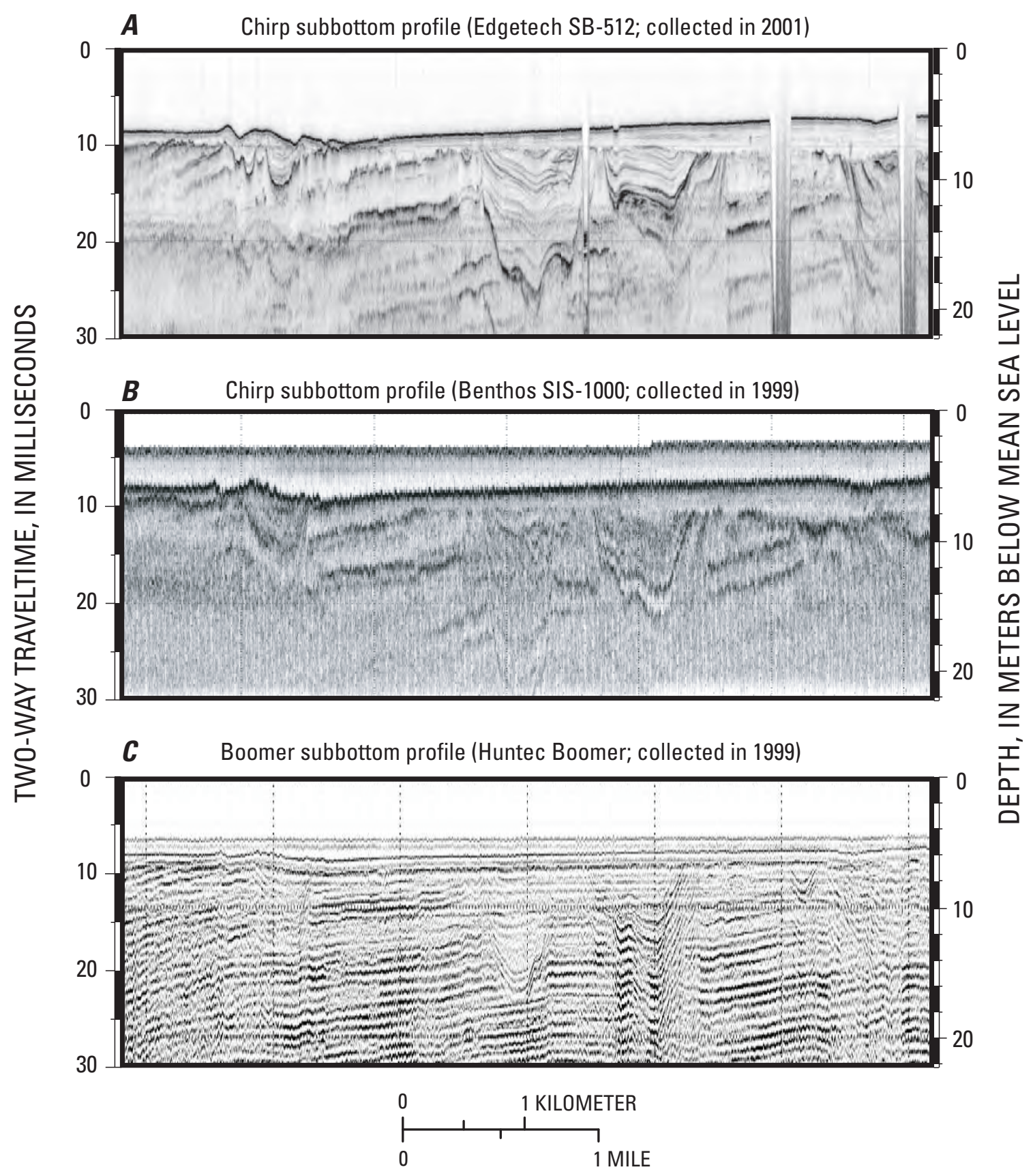

VERTICAL SCALE GREATLY EXAGGERATED

Figure 2.6. Subbottom profiles collected with three different systems along the same trackline offshore of Murrells Inlet (location shown in figure 2.4). A constant seismic velocity of $1.5 \mathrm{~km} / \mathrm{s}$ was used to convert traveltime to depth. Modified from Baldwin and others (2004). 


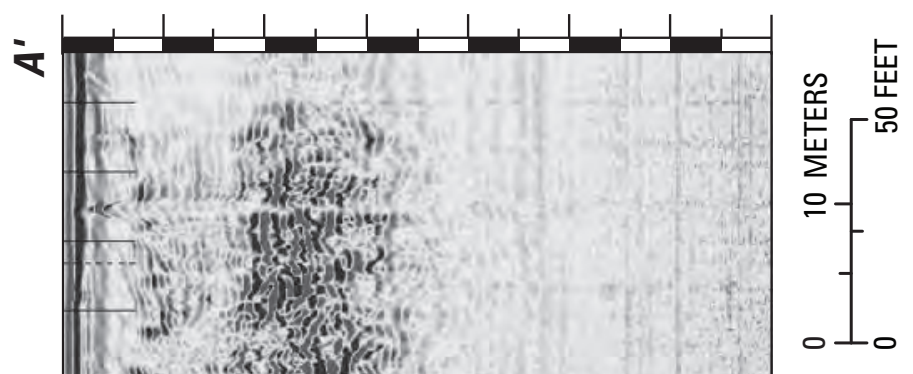

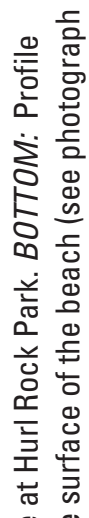

웅

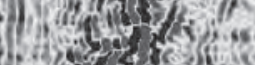

는 은

즁

일

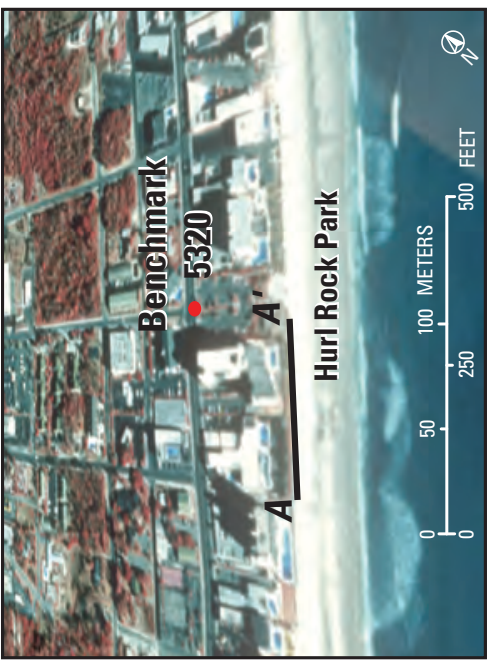

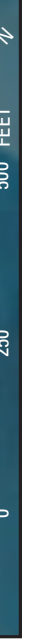
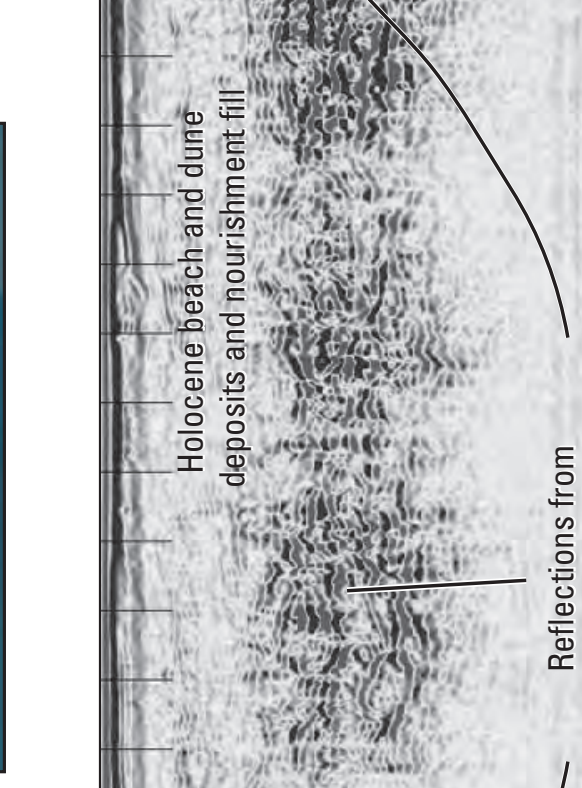

ब ह

응

o $x$. n.

(4)

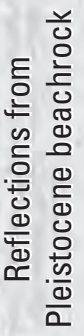

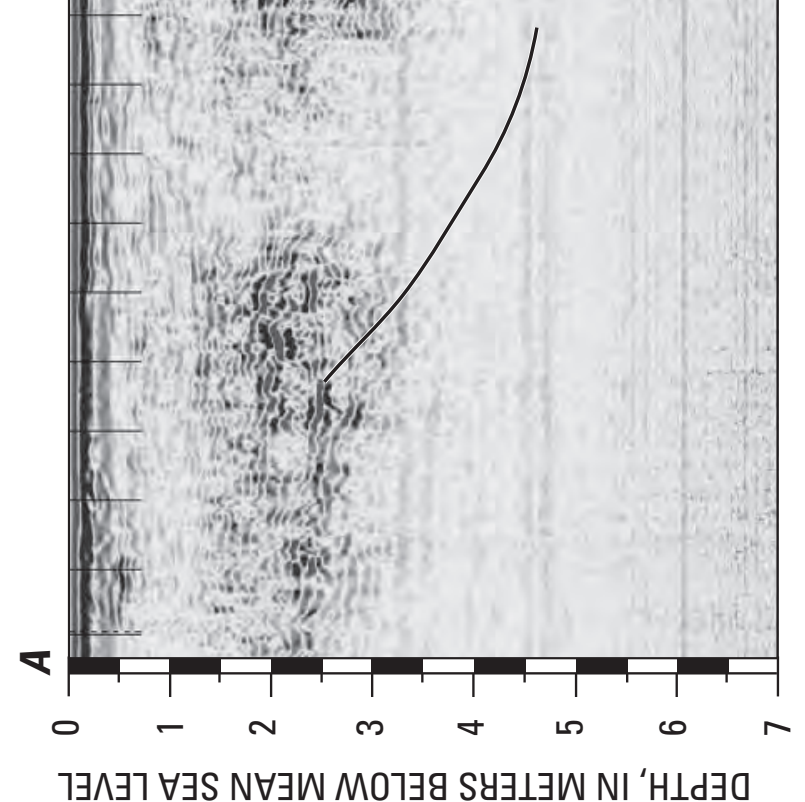

苋苛

ฮิ

产

흫 ख

늠

式

듄 $\frac{01}{2}$

.

号 觉

흔

ن \&

衣

. 듕

듬

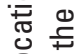

을 동

๑

政

$\sum_{i}^{2}+$

4

등

흥 응

음 흔

즌

눈

官

㟧

등

잉

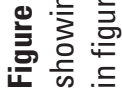




\subsection{Mapping Shorelines}

Sandy shorelines are dynamic systems that change in response to natural processes or human modifications to the coast. Change is measured by comparing shoreline positions at different points in time from days to many years apart. The shoreline at any particular beach is established from features visible in the field or on aerial photographs (for example, wet-dry line, vegetation line), features measured from beach profiles (for example, crest of the primary dune), or elevation contours extracted from topographic surfaces (for example, mean high water).

\section{Beach Profiling}

Beaches in South Carolina have been monitored since 1993 by using beach profiles taken at established benchmarks along the entire coast. In its simplest form, a beach profile is constructed by a survey crew who use leveling instruments to determine the elevation of a series of points along a line. Profiles generally begin at the dune, cross the dry beach, and end in the surf zone at wading depths of less than $2 \mathrm{~m}$. Survey results are presented as a graph of land elevation relative to distance along the profile (fig. 2.8). Surveys along the same profile are collected at regular time intervals so that changes in the shape of the

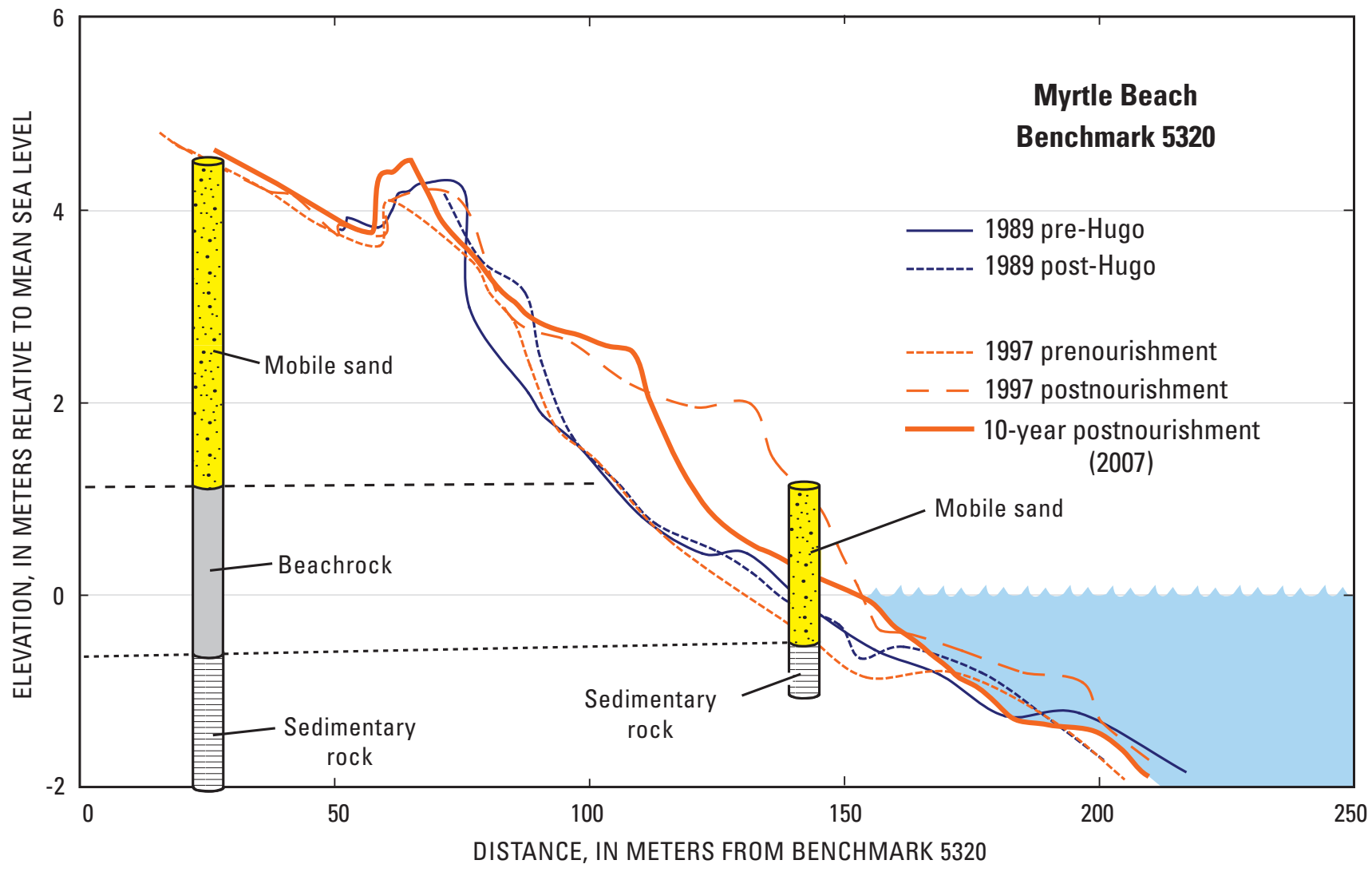

Figure 2.8. Beach profiles measured at Myrtle Beach (location shown in figure 2.4) over a 10-year period showing changes in beach shape. Blue lines represent the beach before and after Hurricane Hugo struck in 1989, causing extensive erosion. The 1997 prenourishment profile shows limited amounts of mobile sediment overlying beachrock and sedimentary rock, which commonly were exposed along the beach and shoreface. Later that year, a large amount of new sediment was pumped onto the beach and buried the rocky outcrops beneath a wide, sandy berm. Ten years after the nourishment, the beach fill has eroded but continues to cover the rocks. See figure 4.5 for location of transect. 
beach can be monitored on a seasonal or yearly basis. Changes in beach shape indicate erosion (loss) or accretion (gain) of sediment over that time period.

Geologists at Coastal Carolina University and USGS have improved traditional beach-profiling techniques by extending cross-shore profiles beyond wading depths to water depths of about $8 \mathrm{~m}$. Different techniques are used on land and in the water. To survey the dry beach, Global Positioning System (GPS) navigation receivers are mounted on an allterrain vehicle (ATV) or carried in backpacks on foot. Precise position and elevation data are collected at low tide while surveyors drive or walk along survey lines. To survey in deeper water, surveyors mount a fathometer on a small, rigid-hull inflatable boat that is precisely tracked by GPS (fig. 2.2B). At high tide, the boat drives as close as possible to the beach, thereby overlapping the area covered in land-based surveys. Data from the two surveys are then merged to form a single profile.

\section{Historical Shoreline Analysis}

Analysis of field surveys, historical maps, and aerial photographs reveals long-term trends in shoreline change (Shalowitz, 1964; Anders and Byrnes, 1991). A widely used source for establishing historic shoreline positions is the National Ocean Service (NOS) topographic sheet, or T-sheet. Dating back to the mid-1800s, T-sheets are usually the oldest reliable source of shoreline data and provide a long-term record for most areas of the U.S. coast. Aerial photographs dating from the mid-1900s help to better define long-term trends in shoreline variability. Aerial photography allows rapid surveying of large sections of coast (fig. 2.9) and thereby provides snapshots of the shoreline at more frequent intervals.

In recent years, the use of laser-based techniques for mapping topography has revolutionized shoreline mapping. LIght Detection And Ranging (LIDAR) systems are deployed from airplanes and can rapidly survey extensive areas of the coast (fig. 2.2B). LIDAR systems bounce a laser beam off the ground hundreds of times per second across a wide swath beneath the airplane. The time it takes the laser beam to reach the ground surface and bounce back (or to be reflected) to the airplane is used to calculate elevation. LIDAR systems can map hundreds of kilometers of coast in a few hours and are able to acquire data every few meters (fig. 2.10). The large number of closely spaced topographic measurements is used to establish shoreline positions (Sallenger and others, 2003). Frequent surveying enables examination of shorter term trends in shoreline change, such as the effects of a single storm (Stockdon and others, 2002).

\subsection{Mapping Sediment Movement}

To understand fully how sediment moves within the coastal system, scientists placed oceanographic instruments on the shallow seafloor offshore of the Grand Strand beaches. Current meters, sediment traps, wave-height sensors, and other instruments were attached to sturdy metal frames (tripods) and anchored to the seafloor (fig. 2.11). At regular intervals over a six-month period, these tripods collected time-series measurements of water flow, sea level, seafloor bedforms (ripples), near-bottom turbulence, suspended sediment concentrations, salinity, and temperature (Sullivan and others, 2005). Supplemental data such as wind speed and direction, air temperature, barometric pressure, and streamflow measurements were also collected.

\subsection{Summary}

A suite of high-resolution remote-sensing and sampling techniques were used to define the geologic framework, assess historic shoreline change, and identify oceanographic processes influencing sediment transport along the Grand Strand. Swathbathymetry, sidescan-sonar, and seismic systems describe three primary components of the geologic framework, which forms the foundation of the coastal system; seafloor topography, the distribution of rocks and sediment on the seafloor, and structure and composition of underlying geology. Historical shoreline analysis allows monitoring of short- and long-term trends in shoreline change. Knowledge of the geologic framework and shoreline change is used to site oceanographic studies that measure winds, waves, and currents. This multiphase approach helps us to better understand the mechanisms influencing coastal change along the Grand Strand. 


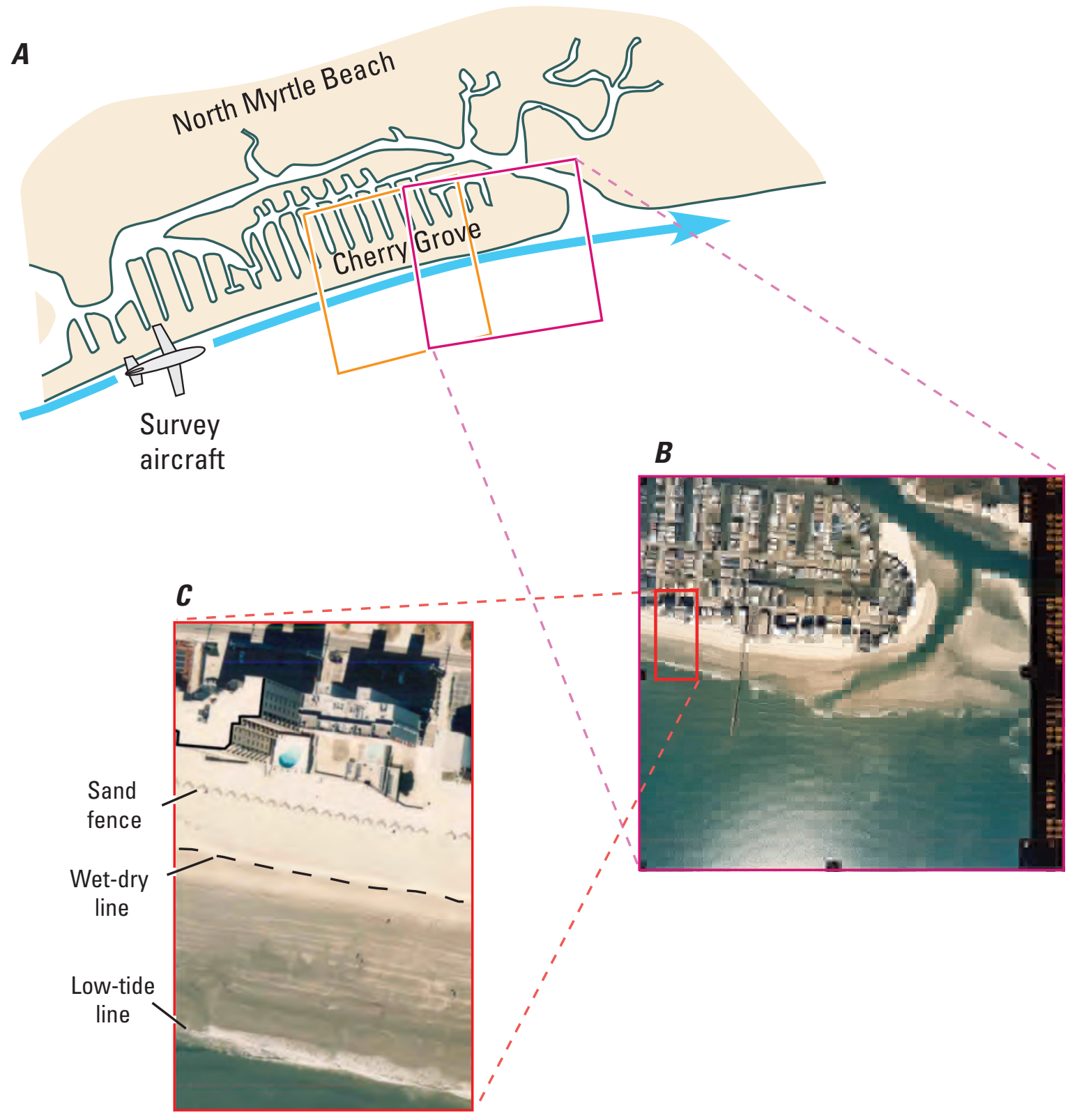

Figure 2.9. (A) Diagram showing the flight path for an aerial photographic survey that followed the coastline in North Myrtle Beach (location shown in figure 2.4). Surveys were conducted at low tide and consisted of adjacent, overlapping photographs to allow for continuous coverage. (B) Example of aerial photograph showing coastal development and shoreline morphology at Cherry Grove (location shown in figure 1.3B). (C) Enlarged area of the photograph showing prominent features such as the sand fence, wet-dry line, and low-tide line. The wet-dry line is typically used to delineate shoreline position on aerial photographs. Successive surveys are compared to assess changes in shoreline position over time. Sand fences are constructed of evenly spaced, wooden vertical slats approximately four feet in height, and are designed to build sand dunes by trapping wind-blown sand and to protect existing dunes and vegetation. 


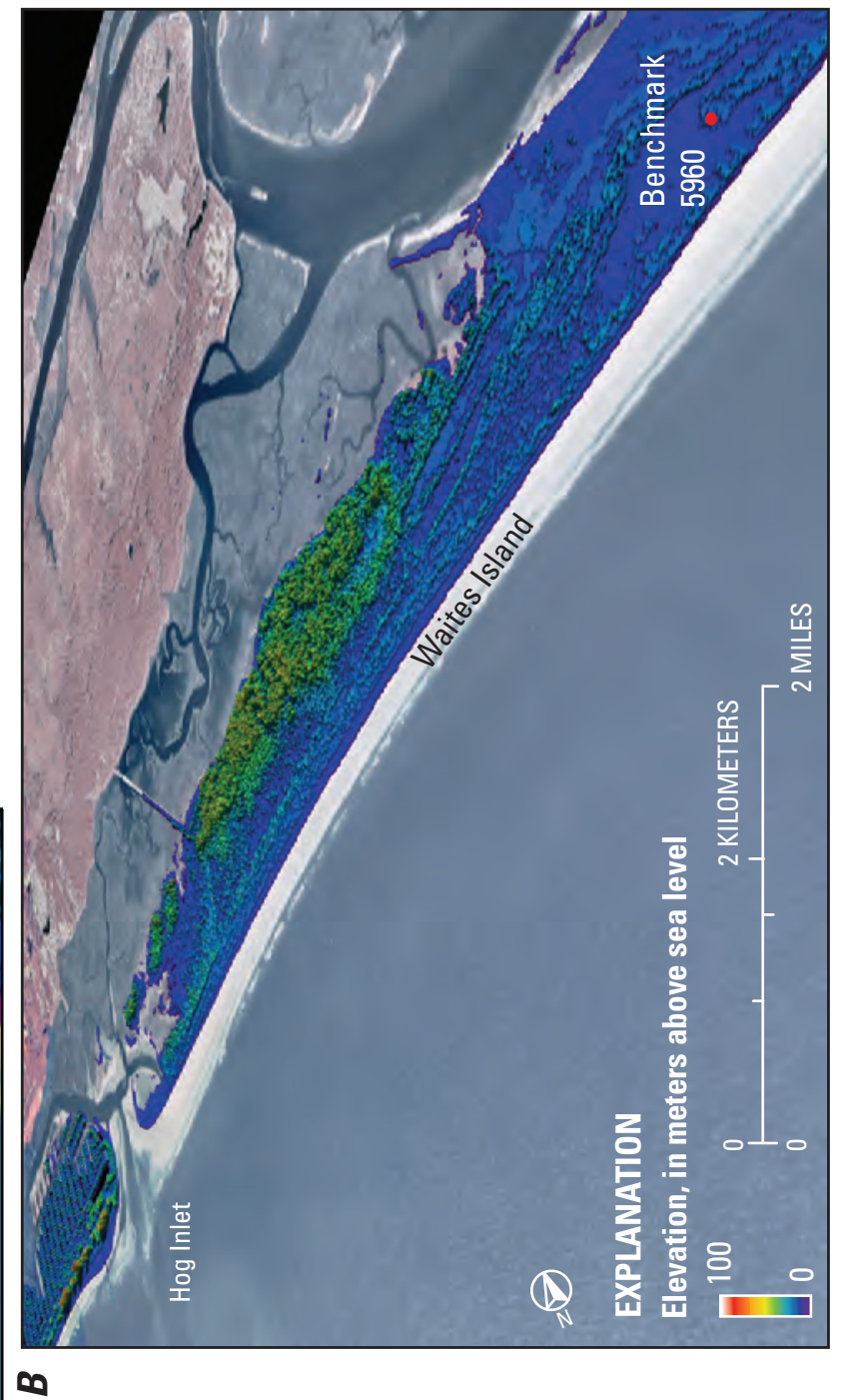

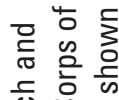
등 항 Фे हे들 步它 $\sum{ }^{\circ}$ 志志总 틍 틈 은 훙 흔 흠응

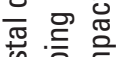
흥.흥 $0 \sum^{\pi}$ 证 跑 정 3응 少元 $\frac{5}{0}$ 음 홍 ‘ 응 는 紫至 응용 당 言. 喤

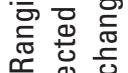
完 $\overline{\overline{0}}$

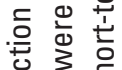
\& 苋苋品 듬히 중 专 $\frac{0}{3}$

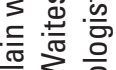
준 3 व

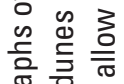
훙 훙 흗 하월 응 递完 항 흥ㅎㅎ 일 웅잉

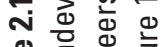

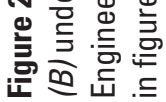


$\boldsymbol{A}$

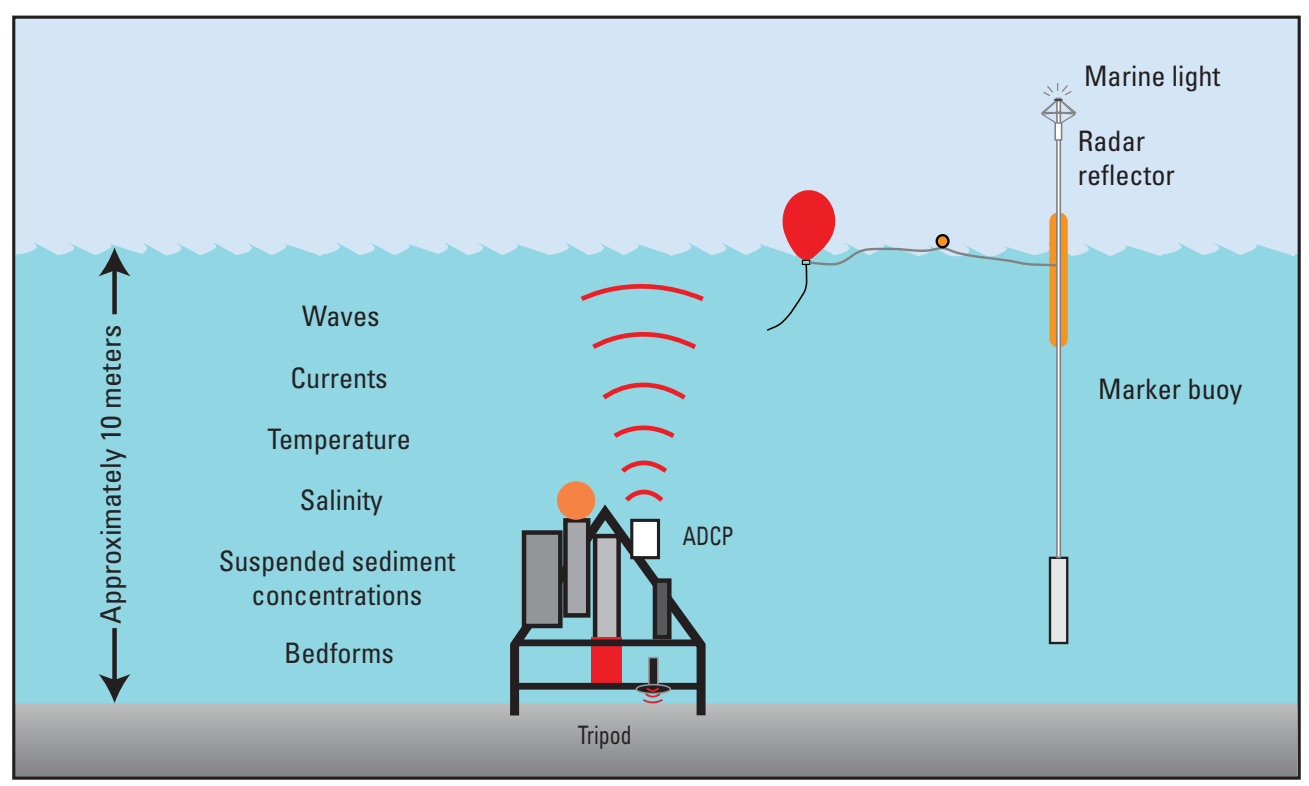

Not to scale

\section{$B$}
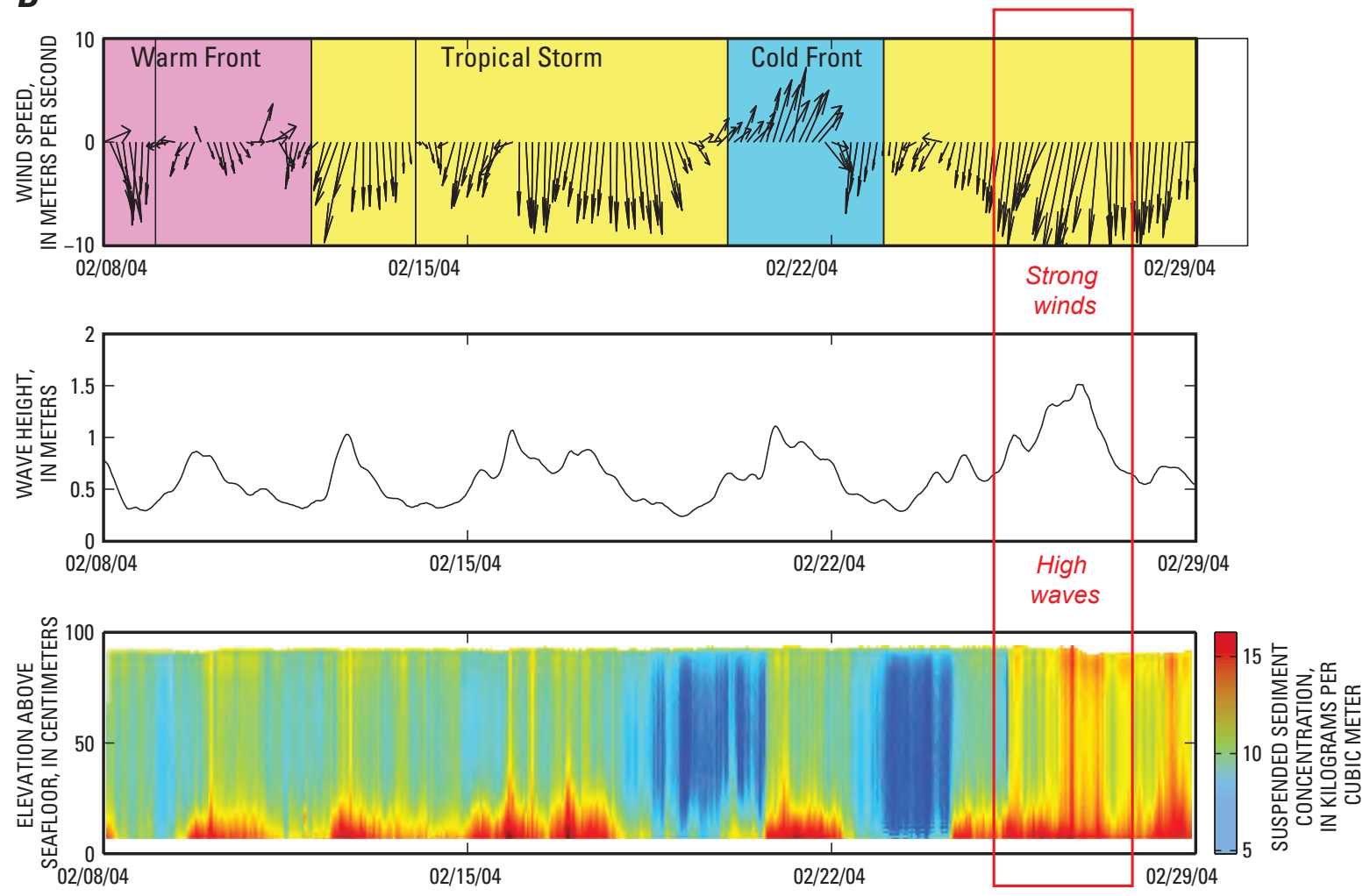

DATE

High concentration

of sediment in water column

Figure 2.11. (A) Diagram showing oceanographic instruments deployed offshore of Myrtle Beach (locations shown in figure 5.5) as part of the South Carolina Coastal Erosion Study (SCCES). The tripod frame and instruments were anchored to the seafloor, collecting data at regular intervals over a six-month period. ADCP, Acoustic Doppler current profiler. Modified from Bothner and Butman (2007). (B) Graphs showing data for wind speed and direction (top), wave height (center), and suspended sediment concentrations in the water column (bottom). Red box indicates a period of strong winds and high waves on February 26 to 27, 2004, which mobilized sediment from the seafloor and suspended it in the water column. 


\subsection{Introduction}

he Grand Strand geologic framework consists of an ancient sedimentary-rock foundation that is overlain by younger unconsolidated sediment (fig. 3.1). Unconsolidated sediments measure up to $30 \mathrm{~m}$ thick landward of the shoreline but thin significantly in offshore areas. Modern sediment is largely absent across much of the shallow seafloor of Long Bay, and exposures of older sedimentary rock are common (fig. 3.2). The framework components have been eroded to various degrees, and the remains of these components provide a fragmented geologic record that spans about 70 million years (table 3.1).

\subsection{Framework Components}

\section{Cretaceous and Tertiary Sedimentary Rocks}

The layered succession of sedimentary rocks underlying the region was deposited between about 70 and 55 million years ago during the Cretaceous and Tertiary Periods (table 3.1; fig. 3.1A). Fossilized remains of marine organisms indicate that the rocks were originally deposited as sandy and muddy sediment in continental-shelf settings. Over time, a combination of biochemical and geochemical processes cemented the loose particles of sediment together to form sandstones, siltstones, and mudstones (fig. 3.3).

Erosion has sharply truncated the rocks since their deposition and created a broad, low-relief surface that slopes gently seaward across the region. Locally, rivers and streams eroded deep channels into the rocks during times of lower sea level (figs. 3.2, 3.4). These paleochannels differ in size and shape (fig. 3.5A), indicating that they were formed by different types of fluvial systems, including large rivers, small tributaries, marsh creeks, and tidal inlets. The eroded upper surface of the rocks represents an unconformity, which is a gap in the geologic record caused by a combination of erosion and nondeposition. The unconformity represents a time span of about 70 million years in locations where Cretaceous rocks crop out on the seafloor (fig. 3.2).

\section{Pleistocene Sediment}

After the long hiatus represented by the unconformity, sediments began to accumulate on top of the eroded sedimentary rocks about 1.8 million years ago during the Pleistocene Epoch (table 3.1; fig. 3.1B). Deeply buried Pleistocene sediments consisting of sands and gravels fill the network of paleochannels incised into the underlying foundation. These channel-fill deposits are truncated by a second regionally extensive erosional unconformity which has formed in part during the ongoing rise in sea level (figs. 3.2, 3.4).

Pleistocene sediments also compose ancient shoreline deposits that form the coastal upland landward of Grand Strand beaches (fig. 1.6). These shoreline deposits consist of sediments that accumulated in ancient salt-marsh, estuarine, dune, beach, barrierisland, tidal-inlet, and nearshore-marine settings, and their preservation is irregular along the coast (fig. 3.2). South of Surfside Beach, the old shoreline deposits are relatively well preserved landward of modern barrier systems such as North, Debordieu, and Pawleys Islands. To the north, however, where there are no protective barriers, the deposits have been eroded landward of the shoreline. Storm-related erosion periodically exposes semiconsolidated parcels of the shoreline deposits on the beach and upper shoreface, where they form low-relief pavements in places like Hurl Rock Park.

\section{Holocene Sediment}

The modern coastal system includes shoreline and inner-shelf sediment that is actively moved by waves and currents. These mobile, generally sandy deposits are composed of Holocene sediment that has been accumulating since about 7,000 years ago (fig. 3.1C). The deposits lie above the regionally extensive erosional unconformity (figs. 3.2, 3.4), so they are easily distinguishable from older underlying rocks and channel fills. Holocene shoreline deposits are distributed unevenly in a narrow wedge along the coast (fig. 3.2). South of Murrells Inlet and north of North Myrtle Beach, relatively thick and wide accumulations form salt marshes, barrier islands, and spits that lie seaward of the Pleistocene upland. No barrier islands line the Myrtle Beach section of the 

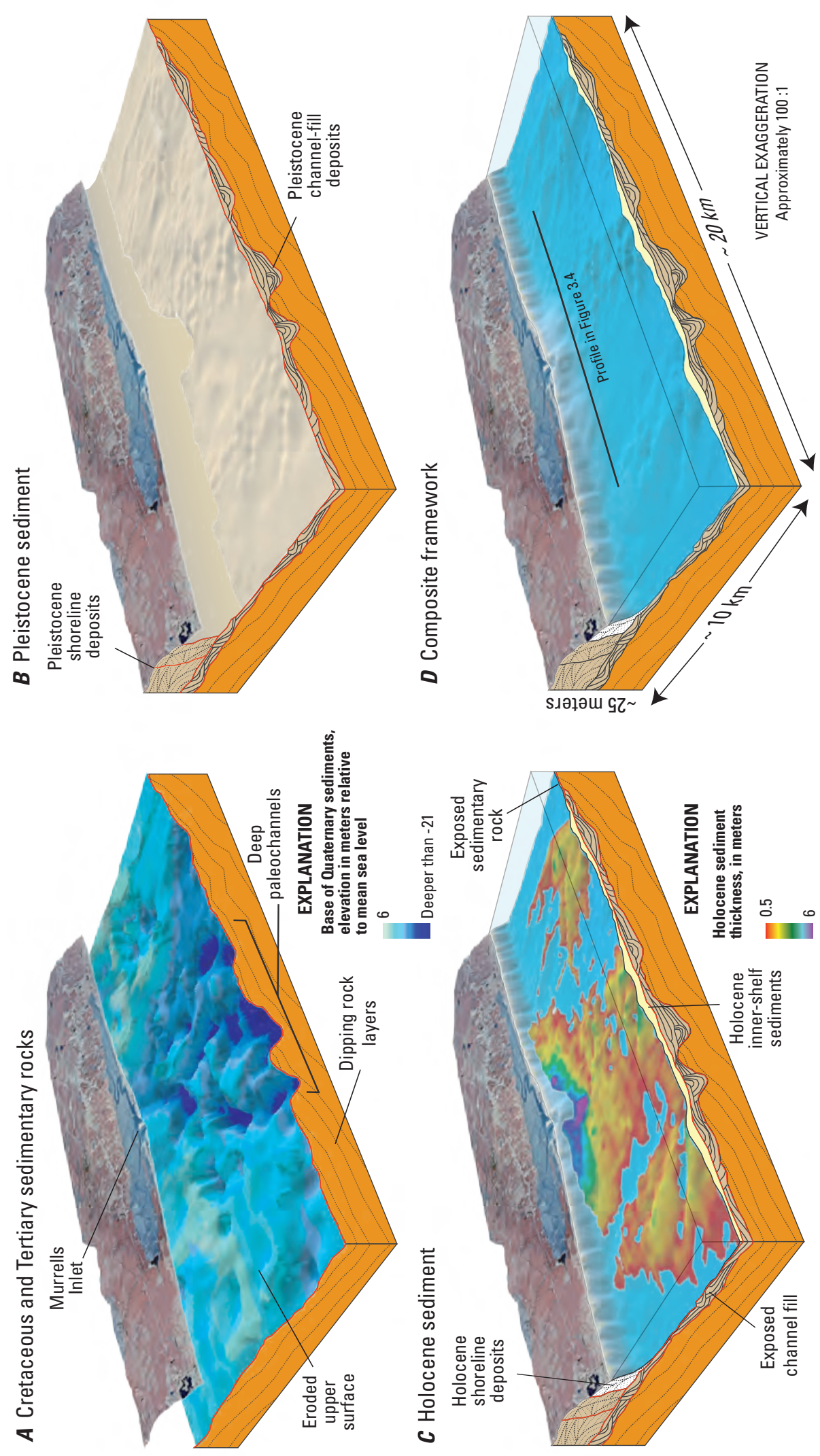

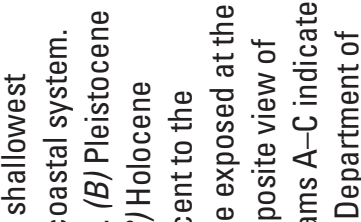
s 0 넌

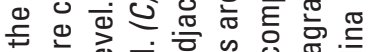

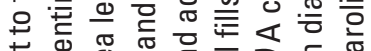
峁 必

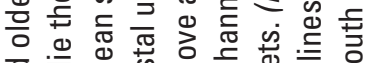
등 范

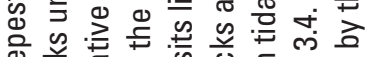

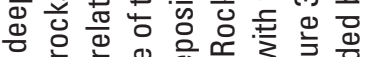

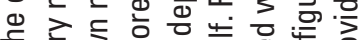

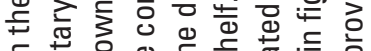

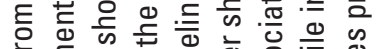
结

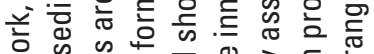

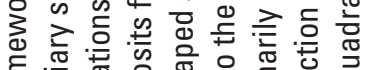
E

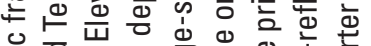

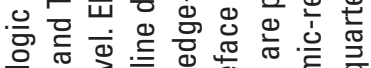

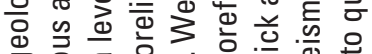
ब。 d 元

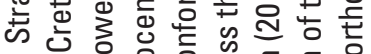

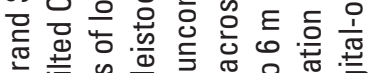

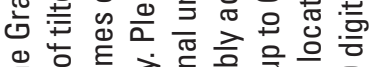

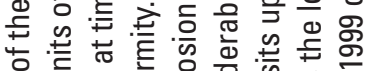

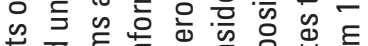

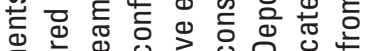

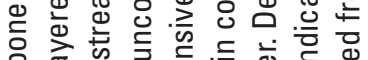

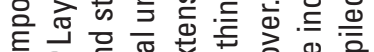

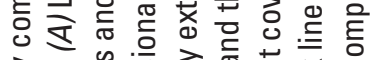

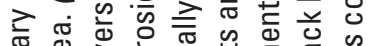

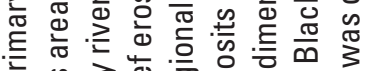

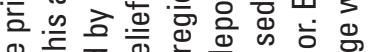
记

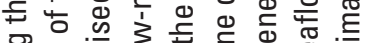

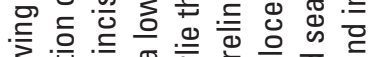

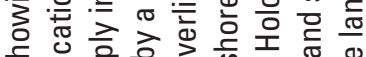

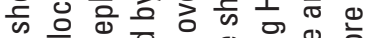
w

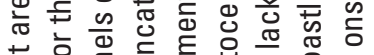

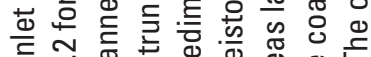

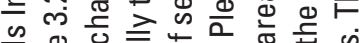

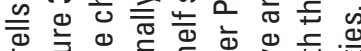

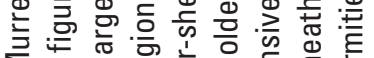
$\sum_{0} \frac{\pi}{\infty}$

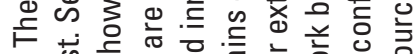
.

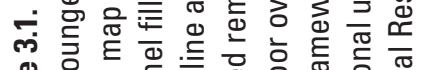

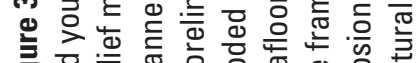

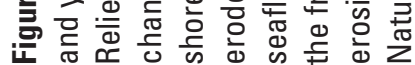



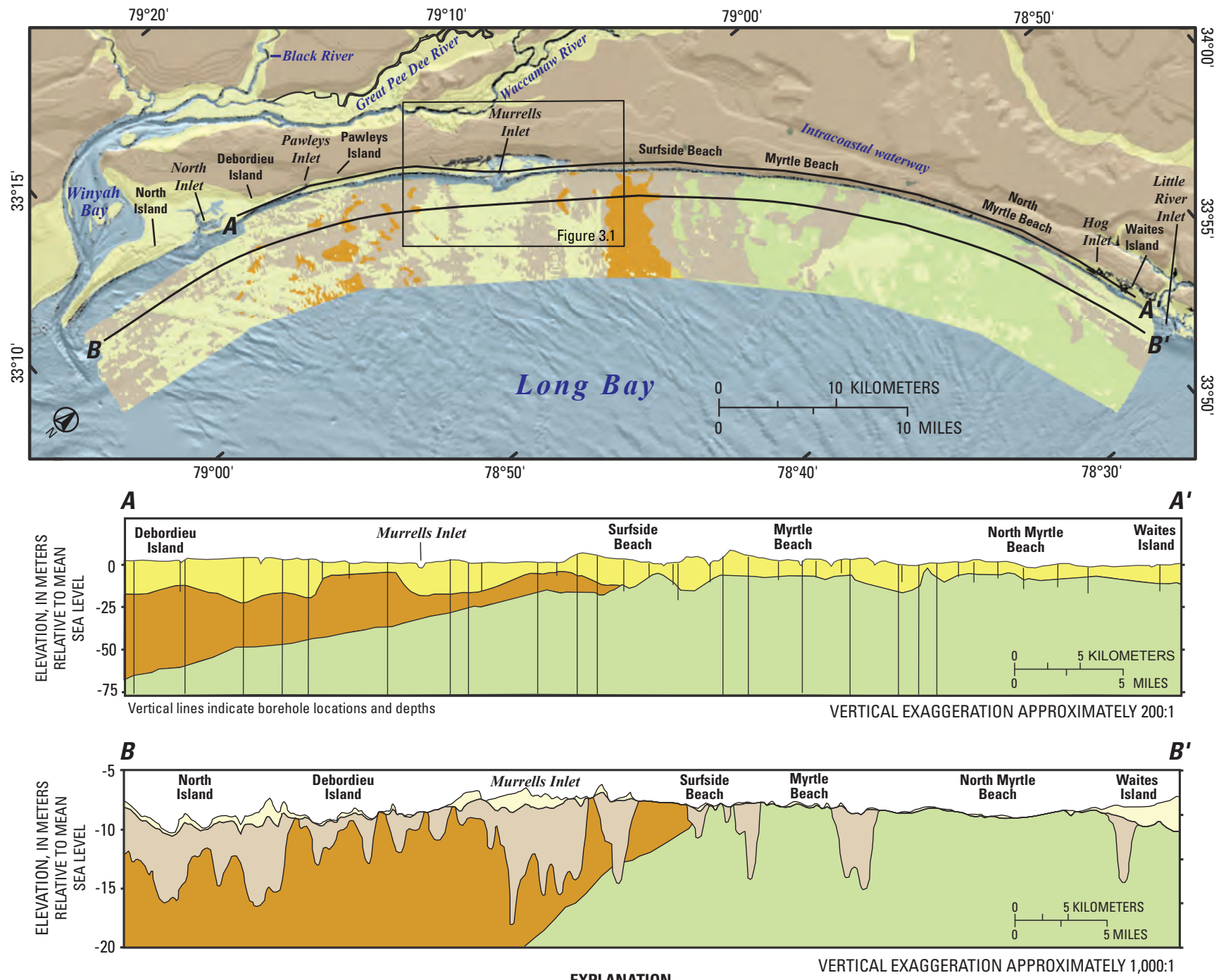

EXPLANATION

Sedimentary rocks

Early Tertiary (between approximately 65 and 55 million years old)

Late Cretaceous (between approximately 90 and 65 million years old)
Unconsolidated sediments

Quaternary (approximately 1.8 million years old to present) $\square$ Holocene (approximately 10,000 years old to present)

Pleistocene (between approximately 1.8 million and 120,000 years old)

Figure 3.2. Surficial geologic map and geologic cross sections showing the regional geologic framework of the Grand Strand coast and Long Bay inner shelf. The underlying foundation is composed of Cretaceous and Tertiary sedimentary rocks, which are incised by deep channels of the ancestral Pee Dee River. Landward of the shoreline (section A-A'), channel-fill deposits are overlain by a section of Quaternary shoreline units between about 10 and $30 \mathrm{~m}$ thick. On the inner shelf (section $B-B^{\prime}$ ), sedimentary rocks and Pleistocene channel fills are regionally truncated by a low-relief erosional unconformity and overlain by a thin, patchy layer of unconsolidated Holocene sediment. Onshore geology is generalized from McCartan and others (1984) and Owens (1989). Offshore geology is from Baldwin and others (2007). Cross section A-A' is modified from Putney and others (2004), and $B-B$ ' is from interpretation of seismic-reflection profiles. The background shaded-relief imagery was constructed by using the NOAA-NGDC coastal-relief model. 
coast, where limited amounts of Holocene sediment form thin, narrow beaches that are directly attached to the eroded mainland.

The wedge of Holocene beach sediment thins seaward and forms a discontinuous veneer on the shoreface and inner shelf of Long Bay. Holocene sediments are less than $0.5 \mathrm{~m}$ thick or absent across most of the inner shelf (an area of about $530 \mathrm{~km}^{2}$ ); as a result, the seafloor largely consists of broad exposures of older rocks and channel-fill deposits (figs. 3.2, 3.5B). Inner-shelf sediments generally increase in abundance toward the southwest. The thickest accumulations (up to $6 \mathrm{~m}$ ) primarily form low-relief linear ridges and shoal complexes that lie seaward of modern tidal inlets and estuaries, including Little River Inlet, Hog Inlet, Murrells Inlet, Pawleys Inlet, North Inlet, and Winyah Bay (fig. 3.5B).
Table 3.1. Geologic time scale from the Jurassic Period to the present day.

[Stippled patterns indicate long segments of geologic time not represented by deposits in the Grand Strand region (that is, times of erosion or nondeposition). Simplified from Palmer and Geissman (1999). Ma, million years before present]

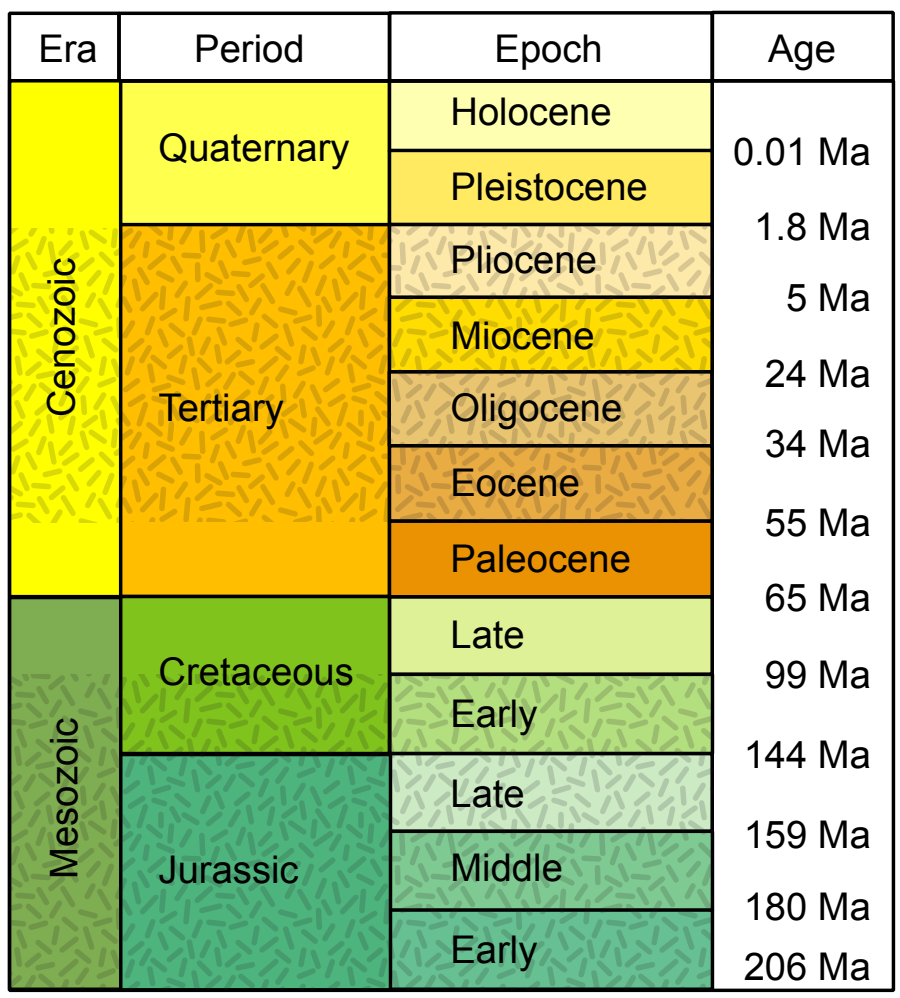

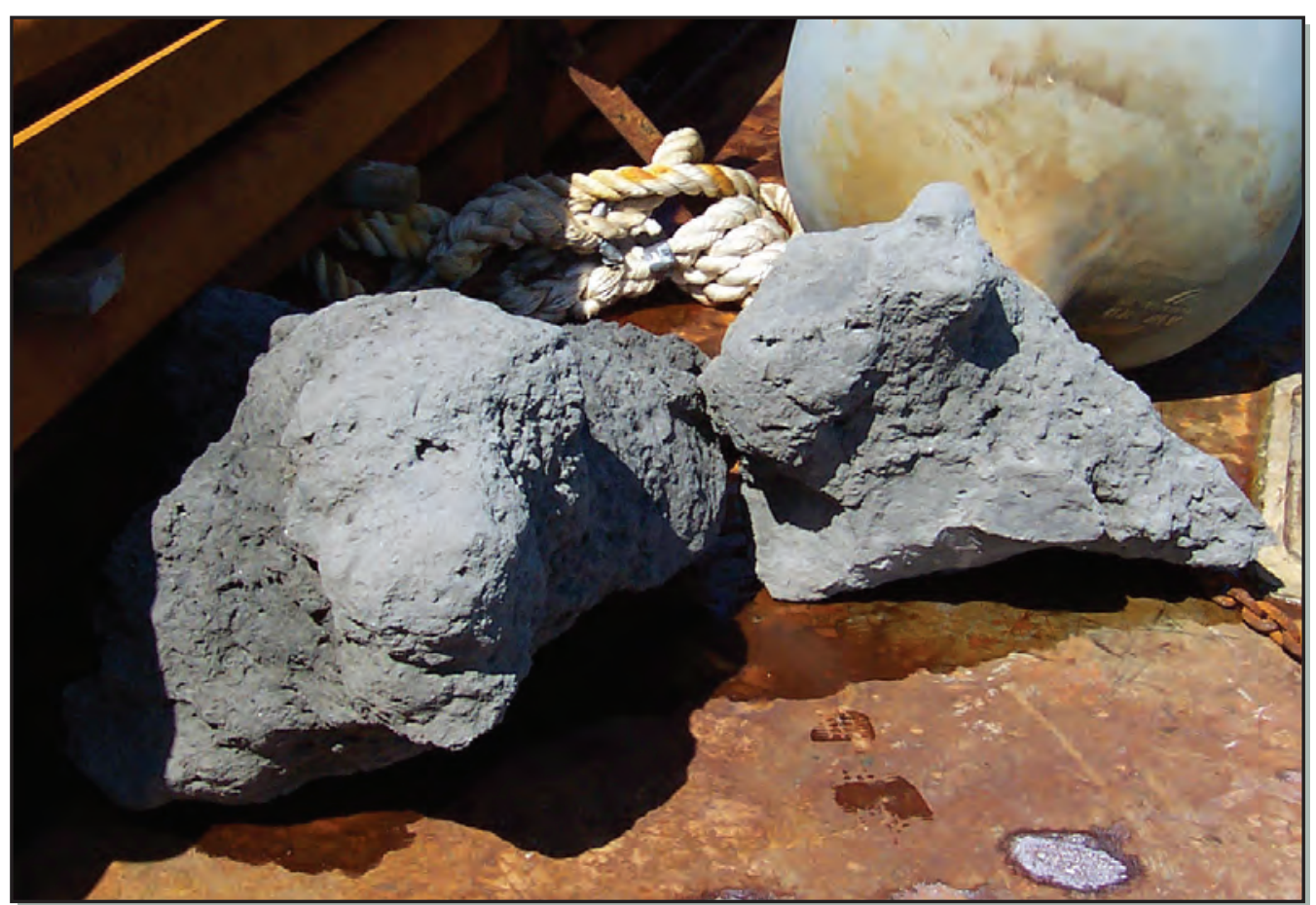

Figure 3.3. Upper Cretaceous sedimentary rock excavated during engineering work offshore of northern Myrtle Beach (published by permission of James Daigle, Sunland Construction, Inc., Eunice, Louisiana). 


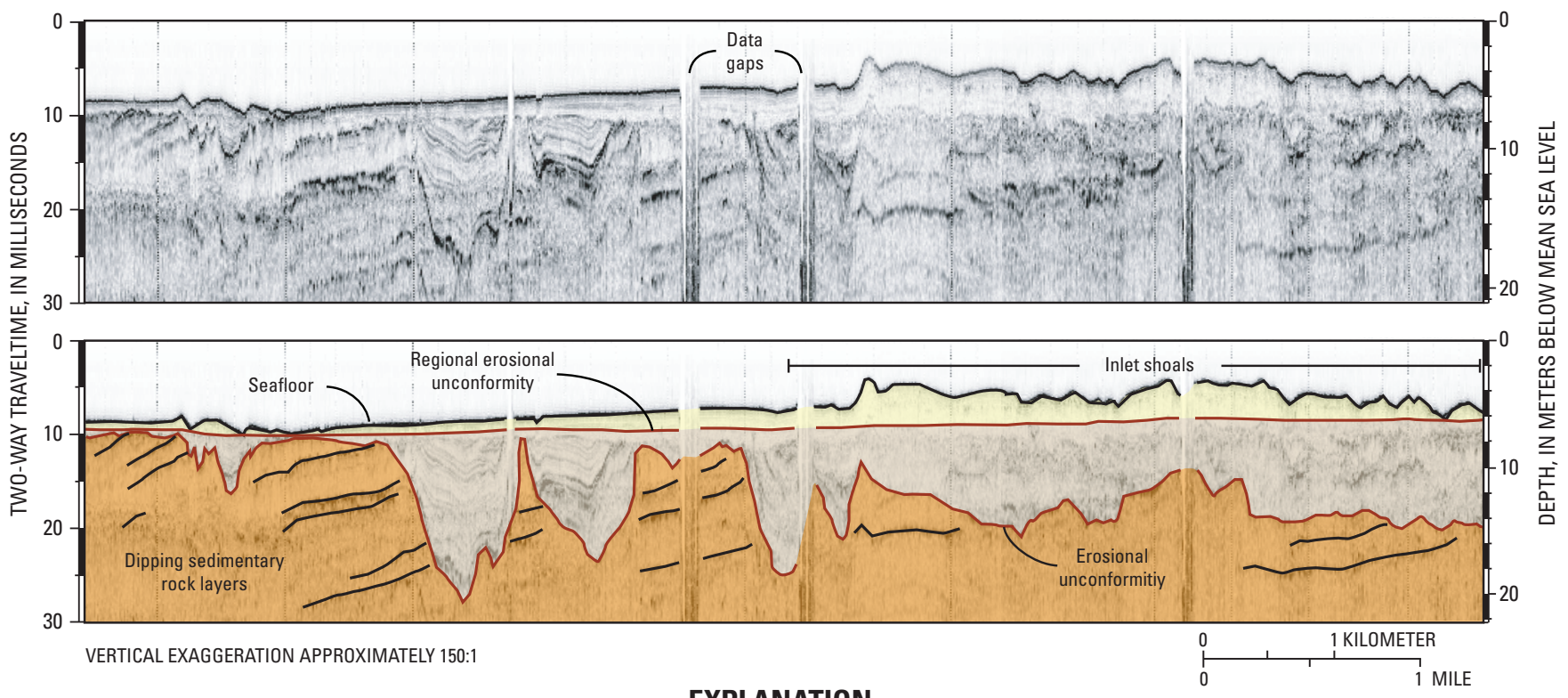

EXPLANATION

Tertiary sedimentary rocks (approximately 55 million years old)
Pleistocene channel-fill sediment (approximately 1.8 million to 120,000 years old)
Holocene inner-shelf sediment (less than 7,000 years old to present)

Figure 3.4. Seismic-reflection profile offshore of the Murrells Inlet area. TOP: Original data showing vertical slice through the upper $20 \mathrm{~m}$ of the seafloor. BOTTOM: Interpreted profile showing the primary framework components underlying the inner shelf. Location is indicated in figure 3.1D. A constant seismic velocity of $1.5 \mathrm{~km} / \mathrm{s}$ was used to convert two-way traveltime to depth (modified from Baldwin and others, 2006).

\subsection{Evolution of the Geologic Framework}

The geologic framework underlying the Grand Strand has evolved over millions of years of Earth history, and it continues to influence the development of the region's modern coastal system. The present study has revealed three basic elements of the framework that highlight the most important aspects of Grand Strand evolution. First, numerous unconformities and extensively eroded geologic units indicate that periods of nondeposition and erosion have been frequent and prolonged. Second, networks of ancient shorelines and deeply-incised paleochannels reveal linkages between cyclical sea-level change, fluvial-system evolution, and changes in sediment supply. Third, narrow and irregularly distributed modern shoreline and innershelf deposits indicate that sediment supply has been particularly limited during the Holocene.
The evolution of the Grand Strand region is viewed in the broad context of continental-margin development, climate-driven changes in sea level, and oceanographic and fluvial processes acting along the northeastern South Carolina coast. This perspective emphasizes how broad-scale changes in the framework have influenced processes that act over increasingly small, local scales. The general scales of influence over Grand Strand geologic evolution (table 3.2) are designated in this report as margin, platform, and coastal, on the basis of their geographic extent and the time periods over which they occurred.

\section{Margin Scale}

Margin-scale influences (scales of 1,000 km and $1,000,000 \mathrm{yr}$ ) are related to the position of the Grand Strand region within the wider geologic framework of the U.S. Atlantic continental margin (table 3.2). The 


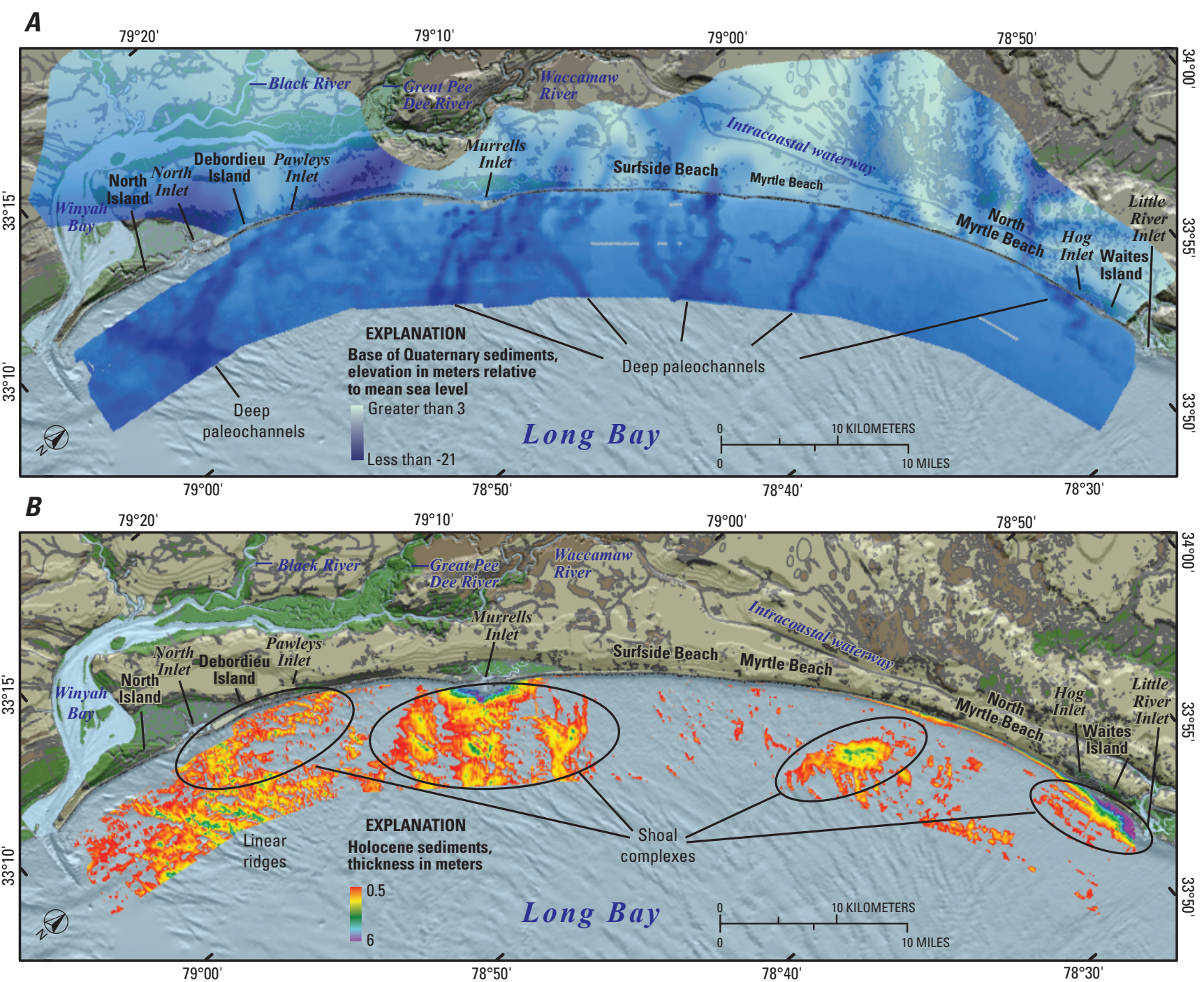

Figure 3.5. (A) Topography on top of Cretaceous and Tertiary sedimentary rocks (base of Quaternary elevation) beneath the Grand Strand. Elongate depressions (shown in the darkest blue colors) crossing this generally low-relief surface represent paleochannels incised by fluvial systems since the Late Pliocene (about 2.1 million years ago). The largest paleochannels were produced by the Pee Dee River, which has occupied multiple courses across the region during the geologic past (see figure 3.9). Modified from Putney and others (2004) and Baldwin and others (2007). (B) Map showing thickness of Holocene inner-shelf sediments, which generally increase in abundance from north to south. Holocene sediments are less than $0.5 \mathrm{~m}$ thick or absent over large areas. The largest accumulations (up to $6 \mathrm{~m}$ thick) generally form shoal complexes that extend seaward from tidal inlets. A notable exception is a shore-oblique shoal offshore of Myrtle Beach. Modified from Baldwin and others (2007). The background shaded-relief imagery was constructed by using the NOAA-NGDC coastal-relief model and USGS hydrography data. 
Table 3.2. Three general scales of influence on the geologic evolution of the Grand Strand.

\begin{tabular}{|c|c|c|c|}
\hline Scale & Margin & Platform & Coastal \\
\hline Spatial influence & $\begin{array}{l}\text { U.S. Atlantic Margin (thousands of } \\
\text { kilometers) }\end{array}$ & $\begin{array}{l}\text { Carolina Platform (hundreds of } \\
\text { kilometers) }\end{array}$ & $\begin{array}{l}\text { Coastal Zone (less than } \\
\text { hundreds of kilometers) }\end{array}$ \\
\hline $\begin{array}{l}\text { Geologic and geomor- } \\
\text { phologic influence }\end{array}$ & $\begin{array}{l}\text { Margin basement structures (plat- } \\
\text { forms and embayments); long- } \\
\text { term patterns of infill and erosion }\end{array}$ & $\begin{array}{l}\text { Emergence-submergence; repeated } \\
\text { subaerial and marine erosion; Pee } \\
\text { Dee River migration; changes in } \\
\text { sediment supply }\end{array}$ & $\begin{array}{l}\text { Coastal landforms and } \\
\text { morphologies; changes in } \\
\text { sediment supply }\end{array}$ \\
\hline Dominant processes & $\begin{array}{l}\text { Differential subsidence caused by } \\
\text { tectonic changes; global climate } \\
\text { and sea-level changes }\end{array}$ & $\begin{array}{l}\text { Global climate and sea-level changes; } \\
\text { fluvial, tidal, current, and wave } \\
\text { energy; differential erosion }\end{array}$ & $\begin{array}{l}\text { Tidal, current and wave energy; } \\
\text { differential erosion }\end{array}$ \\
\hline $\begin{array}{l}\text { Grand Strand frame- } \\
\text { work characteristics }\end{array}$ & $\begin{array}{l}\text { Predisposition to sediment limitation; } \\
\text { shallow, truncated Cretaceous and } \\
\text { Tertiary sedimentary rocks }\end{array}$ & $\begin{array}{l}\text { Pleistocene shoreline units; paleo- } \\
\text { channels and fills; erosional uncon- } \\
\text { formities }\end{array}$ & $\begin{array}{l}\text { Holocene shoreline units; } \\
\text { modern coastal features; } \\
\text { erosional unconformities }\end{array}$ \\
\hline
\end{tabular}

following description of margin evolution is based on studies by Owens and Gohn (1985), Popenoe (1985), Popenoe and others (1990), Klitgord and others (1988), Riggs and Belknap (1988), and Gohn (1988).

About 210 million years ago the continents of North America and Africa began to pull apart, or rift, creating a narrow seaway that eventually widened to become the North Atlantic Ocean. During rifting, the continental crust that formed the margin was faulted into a series of coherent blocks. While the ocean basin widened, the crustal blocks deformed and differentially subsided as they cooled and were buried by massive amounts of sediment. These tectonic adjustments warped the basement rocks into a series of structural highs and lows. The highs, called platforms and arches, formed where the crust subsided least. The lows, called embayments, basins, and troughs, formed where it subsided most. Northeastern South Carolina overlies a prominent structural high called the Carolina Platform (fig. 3.6). Interactions between this structure, global sea level, and oceanographic currents have strongly influenced patterns of deposition and erosion since the Late Jurassic (table 3.1). Sediment deposits are as thick as $3 \mathrm{~km}$ within the adjacent Albemarle and Southeast Georgia Embayments but thin to less than $500 \mathrm{~m}$ across the shallowest, most stable portion of the Carolina Platform, which is called the Cape Fear Arch or Mid-Carolina Platform High (MCPH).
The Grand Strand region was predisposed to long-term sediment limitation early during margin development because of its location near the apex of the MCPH. The region was a depositional center during the Late Cretaceous and early Tertiary, when global climate was warm and sea levels were generally much higher than present (fig. 3.7A). Thick sediments accumulated across calm continental shelves, roughly paralleling the topography of the underlying structure (fig. 3.6B). Nondeposition and erosion became dominant during the Middle to Late Eocene (between about 50 and 34 million years ago; table 3.1), when an ancient equivalent of the Gulf Stream current temporarily flowed across the $\mathrm{MCPH}$ (fig. 3.6A). The current prevented deposition, removed earlier Eocene deposits, and truncated Lower Tertiary and Upper Cretaceous units. A cooler global climate and the formation of polar ice sheets generally lowered sea level throughout the remainder of the Tertiary Period (fig. 3.7A). As sea level fell, sediment mostly continued to accumulate across the relatively low-relief embayments and areas farther seaward, while minimal deposition and erosion prevailed across the MCPH.

The shallow burial and truncation of sedimentary rocks that form the foundation of the Grand Strand resulted from the unique history of structural development, deposition, and erosion along this portion of the margin. The slight downward tilt, or dip, of the rock layers away from the apex of the MCPH reflects how 


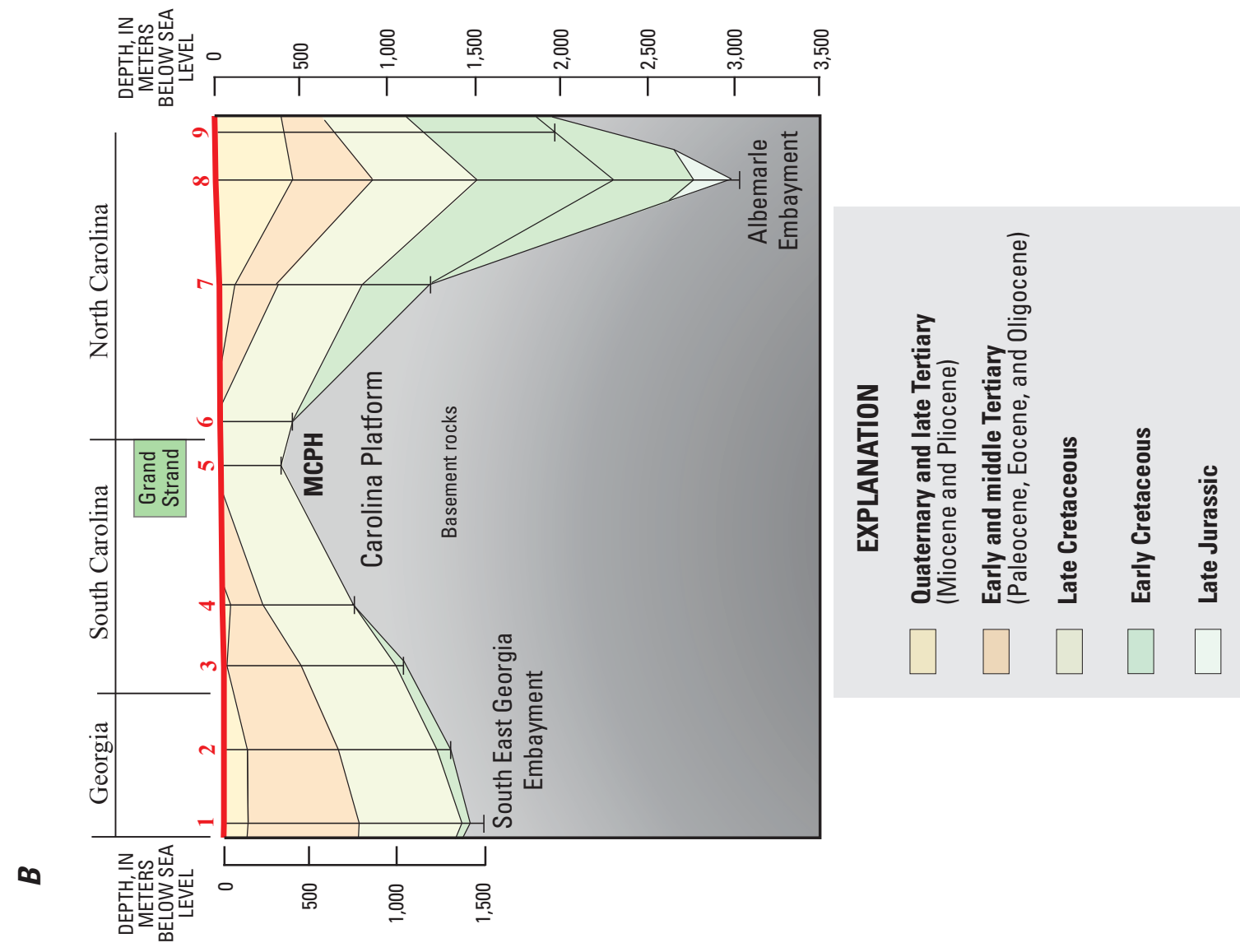

兽苋

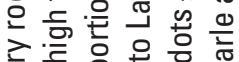
품 응

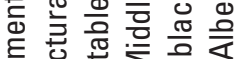
政 is कs

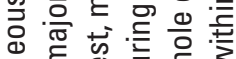
ॠ

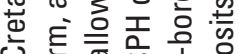
U는 $0 \frac{\pi}{2} 000$ क 응. 을 든 은 응 웡 원 $\frac{}{3}$ 这

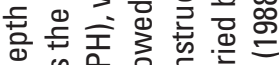

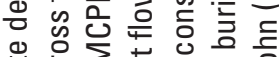

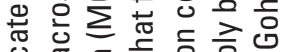
凊 क क ब

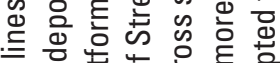

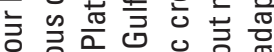

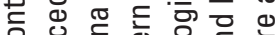

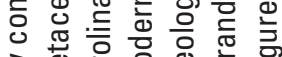
उ क市

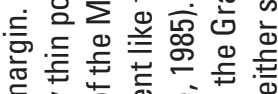
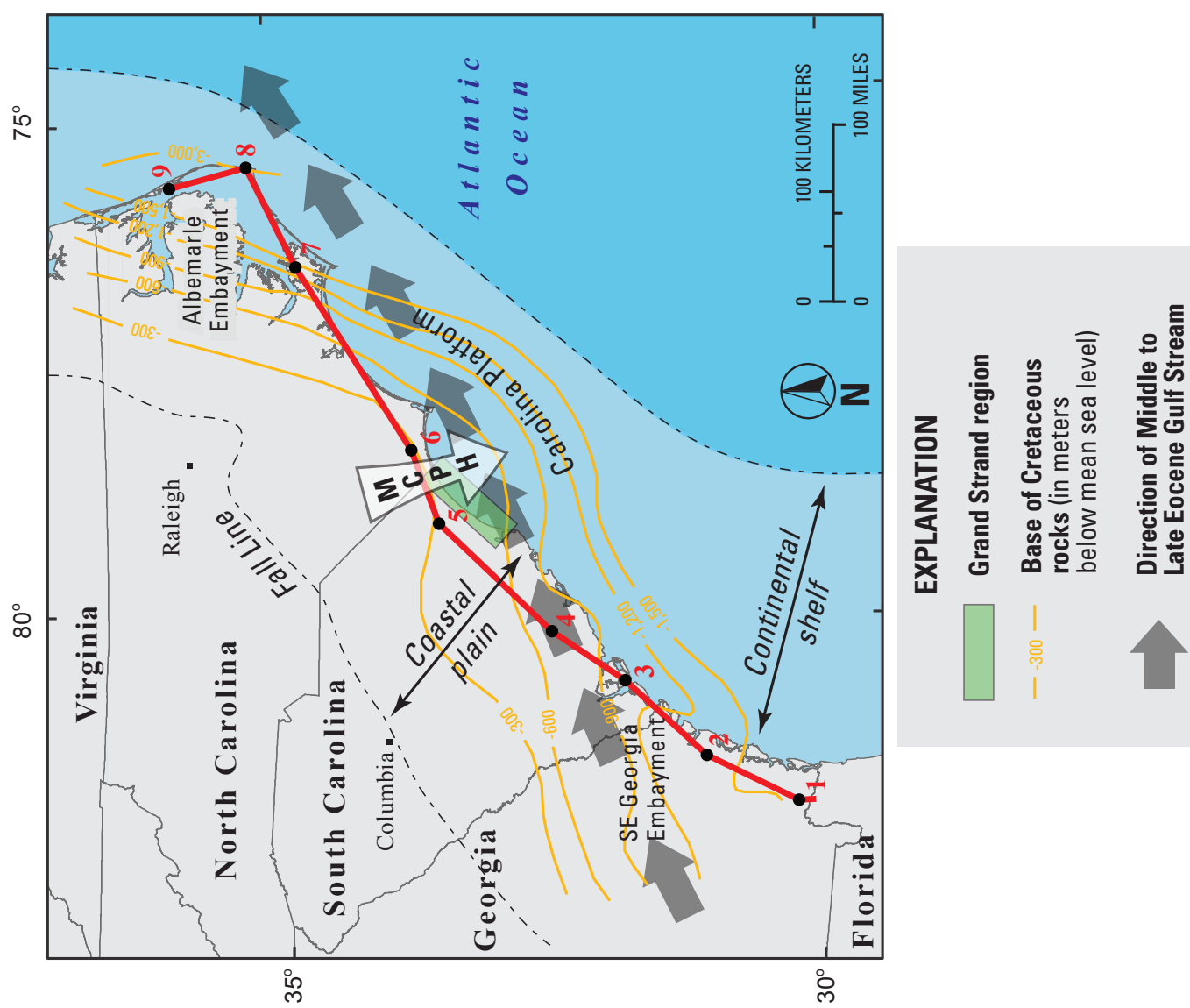

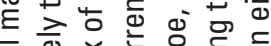
元. 产 离 言焉

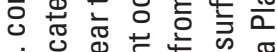

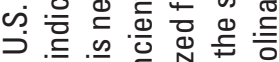
为 的 元

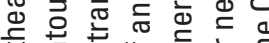

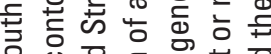

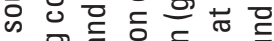
을 은 은 음 흔 응

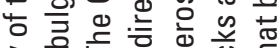

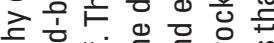

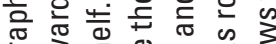
힝 交 离 등 응 응

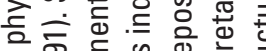
음 ฮ

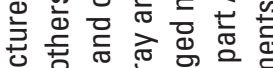

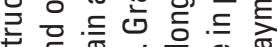

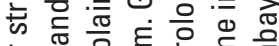

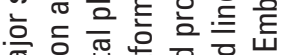

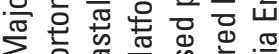

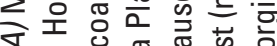
【 든 导 응 잉

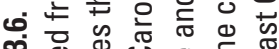
\% ఖ

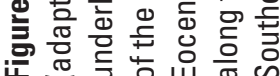




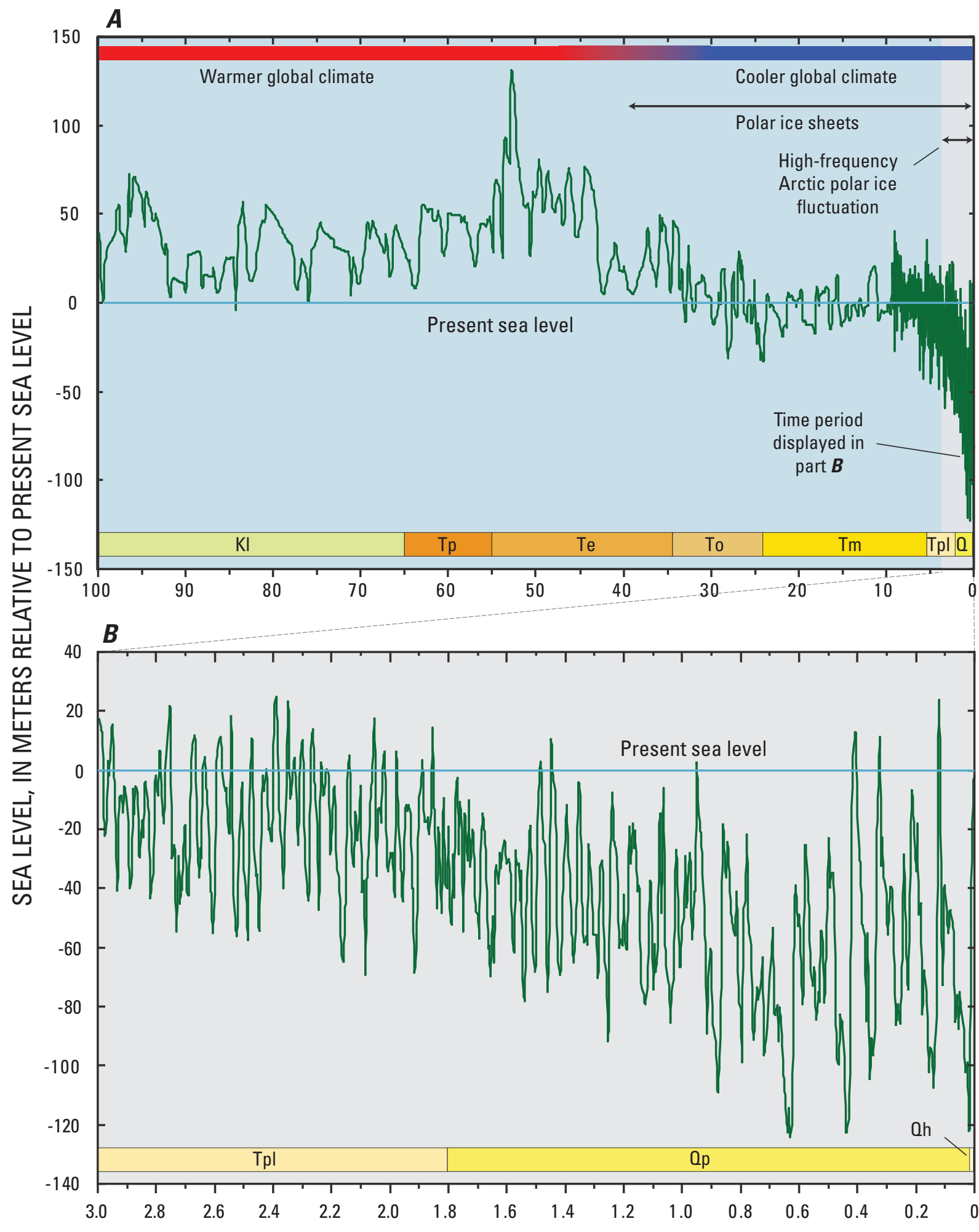

MILLIONS OF YEARS BEFORE PRESENT

Figure 3.7. (A) Global sea level and general climate conditions over the past 100 million years. Grey box indicates ongoing period of high-frequency sea-level changes caused by ice-volume fluctuations over the past 3 million years. (B) Section showing sea level over the last 3 million years enlarged from the graph in part A. Sea-level curves simplified from Miller and others (2005); climate and glacial-ice information generalized from Moran and others (2006). Color coded bars along the bottom of each part indicate geologic time: KI, Late Cretaceous; Tp, Paleocene; Te, Eocene; To, Oligocene; Tm, Miocene; Tpl, Pliocene; Q, Quaternary; Op, Pleistocene; and Qh, Holocene. 
their deposition generally conformed to the underlying structural trend (figs. 3.4 and 3.6B). The rocks are rather erosion resistant, but cementation differs from layer to layer. Truncation has exposed the dipping layers as parallel units across the surface of the foundation. As a result, erosional resistance differs slightly across the width of the rocky foundation because weakly cemented units are more susceptible to erosion than adjacent, well cemented units.

\section{Platform Scale}

Platform-scale changes (scales of $100 \mathrm{~km}$ and $10,000-100,000 \mathrm{yr}$ ) have occurred as fluctuations in sea level forced shoreline migrations back and forth across the Carolina Platform (table 3.2). Since about 3 million years ago (during the Pliocene Epoch; table 3.1), changes in the volume of Arctic polar ice sheets have caused sea level to repeatedly rise and fall as much as $25 \mathrm{~m}$ above and $120 \mathrm{~m}$ below its present elevation (fig. 3.7; Box \#1). During times of lower sea level, the exposed coastal plain and continental shelf underwent broad subaerial erosion and deep fluvial incision while shoreline deposits accumulated at lower elevations seaward of the modern coast (fig. 3.8). When rising sea level submerged the coastal plain over relatively brief periods, the shoreline was forced to migrate landward and develop at higher elevations. As the shoreline migrated back and forth, wave and current energy continually eroded coastal landforms, redistributed sediment, and generally flattened the landscape. The history of these emergences and submergences is partially preserved across the coastal plain in a series of remnant shoreline deposits (fig. 1.6; Colquhoun and others, 1991; Colquhoun, 1995). The ancient shorelines were deposited during submergences that reached progressively lower elevations over time, and thus decrease in age and elevation toward the modern coast.

Coastal deposits across northeastern South Carolina are primarily composed of sediment supplied by the Pee Dee River, which has transported large volumes of material eroded from the Blue Ridge Mountains, Piedmont, and coastal plain to the coast (Brown, 1980; Meade, 1982; Hayes, 1994). Seven groups of large paleochannels underlying the Grand Strand record a regional southwestward migration of the Pee Dee River between the Late Pliocene and present (figs. 3.5A, 3.9; Putney and others, 2004; Baldwin and others, 2006). The migration was primarily driven by the formation of Pleistocene shorelines during periods when sea level was higher than at the present time. These ridgelike, elongate landforms were deposited across the lower coastal plain over successive submergences, and their orientations rotated from generally eastwest to northeast-southwest trends. Each newly formed shoreline deflected the river to the southwest and forced it to carve a new course during the subsequent period of emergence. During the most recent highstand of sea level about 120,000 years ago, deposition of the Myrtle Beach Barrier caused extreme deflection of the river and eventually forced it to flow parallel to the shoreline (fig. 3.9). This deflection caused the river mouth to move from the central part of the Grand Strand near Murrells Inlet to its southernmost extent at Winyah Bay and thus significantly reduced the role of the Pee Dee River as a source of regional sediment supply. During the Holocene, sediment transported by the river has contributed minimally to shoreline development along the Grand Strand because most of it has been deposited in Winyah Bay (Hayes, 1994; Patchineelam and others, 1999). Beach sediment is now primarily supplied through erosion of older geologic units along the coast and inner shelf. Dominant southwestward sediment transport within Long Bay causes this sediment to preferentially accumulate in southern parts of the region.

Over the past 3 million years, platform-scale changes have profoundly influenced Grand Strand evolution. Fluvial systems that incised the network of paleochannels into the sedimentary-rock foundation caused localized topographic variation across the foundation's otherwise low-relief surface beneath the coast and inner shelf (fig. 3.5A). Differential erosion across the foundation clearly influenced the spatial patterns of this fluvial incision, as Tertiary units south of Surfside Beach are more extensively incised than the more resistant Cretaceous units to the north (fig. 3.2). Additionally, the potential for differential erosion increased as more erodible channel-fill deposits were embedded across the width of the rocky foundation. Alternating periods of subaerial and marine erosion caused continual excavation and gradually deepened the regional unconformity that defines the upper surfaces of channel-fill deposits and sedimentary rocks. Although this long-term 
A Initial sea level
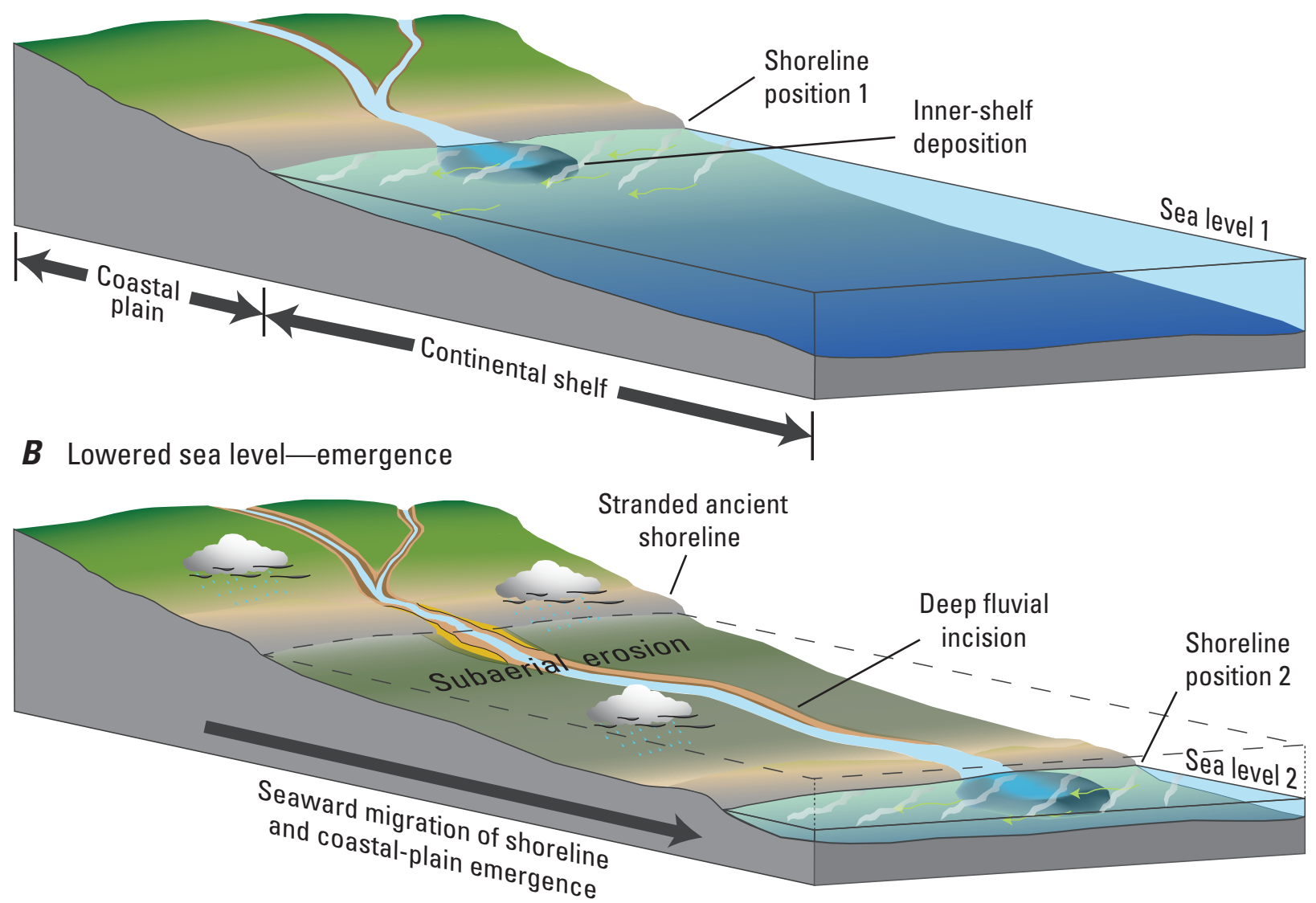

C Elevated sea level—submergence

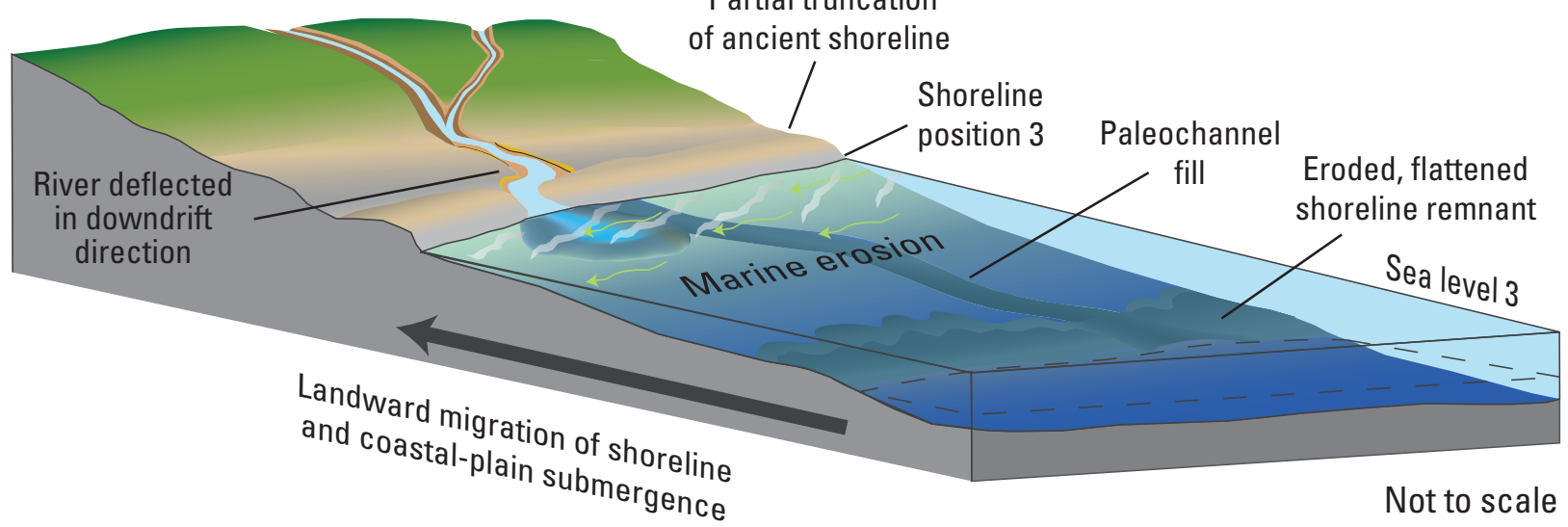

Figure 3.8. A three-phase conceptual model showing evolution of the Grand Strand region over a cycle of emergencesubmergence driven by relative sea-level changes. Diagrams illustrate shoreline migration seaward and landward across the coastal plain and continental shelf. $(A)$ Initial sea level is high; stable shoreline deposits develop at relatively high elevation. (B) Sea level falls and shoreline migrates seaward. Inner shelf emerges, leaving older shoreline stranded high on the coastal plain. Unconformity produced by broad subaerial erosion and deep fluvial incision of the exposed coastal plain. (C) Sea level rises and shoreline migrates landward. Eroded remnants of lowstand shoreline stranded on the continental shelf. Erosion by waves and currents generally flattens the landscape and partially truncates older highstand shoreline. As sea level stabilizes, shoreline deposits accumulate at higher elevations and cause river mouth to migrate downdrift. 

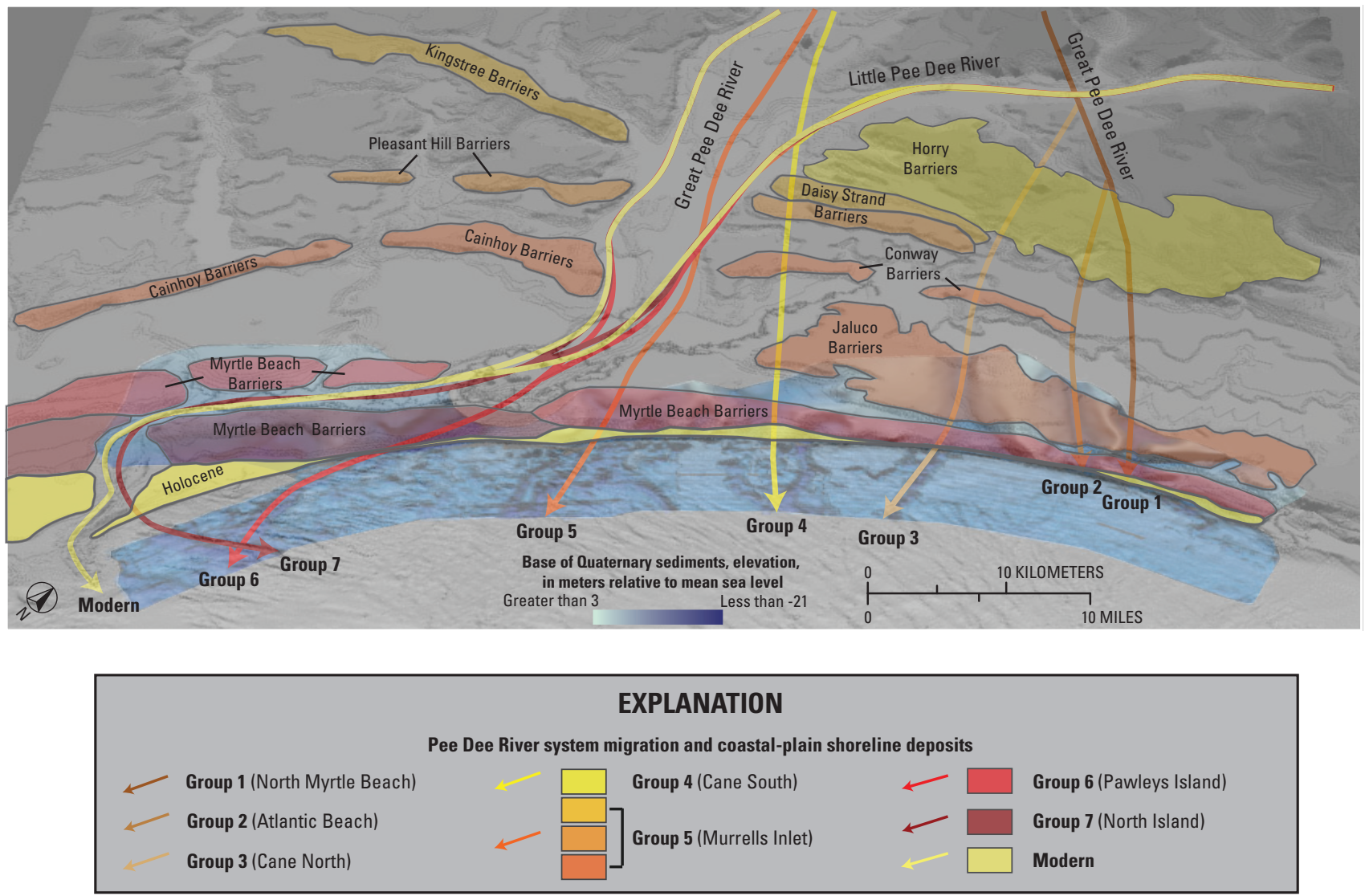

Figure 3.9. Perspective view of the Grand Strand region towards the northwest. Arrows indicate changing locations of the Pee Dee River over time (generalized from Baldwin and others, 2006). Progressive, southwestward deposition along ancient shorelines gradually deflected the river toward the southwest. Older (more landward) shorelines initially trended east-west, but rotated to northeast-southwest as they were deposited progressively closer to the modern coastline. Shaded relief of the regional surface defining the base of Quaternary sediments (also displayed in figure 3.5A) shows that the river carved at least seven distinct courses across the region prior to arriving at its current configuration, which flows through Winyah Bay. The backgroundshaded relief imagery was constructed by using the NOAA-NGDC coastal-relief model.

erosion tended to flatten the landscape, some subtle topography remains across the unconformity. It is notable that younger channel fills south of Murrells Inlet are less flattened than older features to the north because they have undergone fewer periods of emergence and submergence (fig. 3.2). Except for channel-fill deposition, the Grand Strand mostly underwent erosion or nondeposition until about 400,000 years ago. Since that time, successive submergences culminated at elevations near the present shoreline and resulted in the consecutive deposition and partial erosion of Pleistocene shoreline units that compose the coastal upland and Holocene shoreline units that form the modern coast (figs. 3.2, 3.9). Over this time period, platform-scale influences overlapped with smaller, coastal-scale influences and caused the late Pleistocene shift in the dominant mode of regional sediment supply. The shift from a high-volume fluvial source supplied by the Pee Dee River to a lower volume erosional source supplied by coastal and inner-shelf erosion has strongly influenced subsequent coastal-scale changes, which have determined the distribution, configuration, and preservation of shoreline units along the Grand Strand. 


\section{Coastal Scale}

Coastal-scale changes (scales less than $100 \mathrm{~km}$ and 10,000 years) occur as rivers and streams, winds, waves, and currents expend energy across the coastal upland, beach, and nearshore-marine zone (table 3.2). These processes create and modify coastal features such as barrier islands, spits, tidal inlets, marshes, and mud flats, as well as sand ridges and shoals on the inner shelf. Significant coastal deposition has occurred across northeastern South Carolina only when sea level has been relatively high, like today, and slowly rising or falling. During these periods of relative stability, the development of coastal features is determined by the interaction among nearshore processes (wave and current energy), sediment supply, and preexisting geologic framework. Progressive southwestward deposition along the shorelines of northeastern South Carolina suggests a consistent, long-term pattern of domination by wave-driven currents and the resulting longshore transport of sediment. This pattern has apparently remained constant over periods of submergence since the Pleistocene. The growth of the North Island spit across the mouth of Winyah Bay and the concentration of inner-shelf sediment across the southern portion of the region (fig. 3.5B) show that these southerly directed, sediment-transport processes continue to dominate today.

Like older Pleistocene shorelines across the lower coastal plain (fig. 1.6), the late Pleistocene Myrtle Beach Barrier is expansive compared to the Holocene shoreline units that line the modern coast (fig. 3.9). The Myrtle Beach Barrier formed while sediment transported by the Pee Dee River was delivered to the central portion of the Grand Strand, where it could be distributed over a large portion of the coastline. After the mouth of the Pee Dee River migrated southward in the late Pleistocene, its importance as a sediment source was significantly diminished. The river now discharges into Winyah Bay, and little to none of the sediment that it delivers reaches adjacent Grand
Strand beaches. As a result, the modern coastal system is sand limited with thin layers of Holocene shoreline and inner-shelf sediment perched on top of older geologic units. The conditions and extents of shoreline units along the Grand Strand coast clearly illustrate the dominant effects of wave and current energy after the late Pleistocene shift in sediment supply

(figs. 3.2, 3.9). Older shoreline deposits that lie behind the modern beach have been significantly eroded north of Surfside Beach. Predominant southwestward longshore transport has generally prevented sediment deposition along this portion of the coast, and only thin Holocene beaches have developed. In contrast, the Myrtle Beach Barrier is well preserved south of Surfside Beach, where it has been protected by modern barrier islands and spits.

Large, well developed shorelines formed during periods of relatively high sea level when abundant sediment was delivered to Long Bay by the ancestral Pee Dee River. As each successive shoreline formed, topographic relief on the lower coastal plain increased and thereby enhanced the difference in slope between the coastal plain and the adjacent, flat-lying inner shelf. Longshore topographic variability has influenced the shapes of successive shorelines. Waves and currents have differentially eroded the old shorelines and redistributed sediment across lower lying areas. Shorelines have preferentially eroded adjacent to locations where paleochannel fills are embedded into the underlying sedimentary-rock foundation, and this erosional pattern has regionally controlled coastal drainage patterns (fig. 3.2). Salt-marsh creeks and coastal swashes that occupy these depressions drain runoff from higher areas of the coastal upland, and tidal inlets allow for vigorous exchange of tidally driven flow between the depressions and the coastal ocean. The largest accumulations of Holocene innershelf sediments also overlie embedded paleochannel fills because of a combination of inner-shelf erosion and the tendency of adjacent tidal inlets to concentrate sediment. 


\subsection{Summary}

Despite being primarily composed of eroded geologic units that provide a fragmented record, the Grand Strand geologic framework embodies a wealth of information about how geologic, oceanographic, and fluvial processes have influenced its long- and short-term evolution. The present coast has been shaped by the cumulative effect of these processes, which have acted over very different spatial and temporal scales. The scales of these interrelated processes can be placed into three broad categories: margin, platform, and coastal.

At the margin scale, the Grand Strand has been predisposed to sediment limitation over millions of years because of its location within the structural configuration of the U.S. Atlantic continental margin. At the platform scale, widely fluctuating sea levels between the Late Pliocene and present have caused alternating periods of subaerial and marine erosion. At the coastal scale, nearshore marine processes have forced the southwestward migration of the Pee Dee River; this shift diminished its role as the dominant source of regional sediment supply. As coastal processes continued to shape the region during the Holocene, erosion of shoreline and innershelf deposits became the more important mode of regional sediment supply. Driven by coastal wave and current energy, predominant southwestward sediment transport has generally prevented significant deposition along the northern and central portions of the Grand Strand and caused concentrated deposition in the southwestern part of the region. Differential erosion across the geologic framework has influenced the distribution and extent of coastal features and the overall shape of the shoreline. The geologic framework continues to control coastal evolution as sea level slowly rises, and coastal processes continue to erode sediments along the coast and inner shelf. 


\subsection{Introduction}

ry sandy areas such as the berm and dunes represent only a small part of the active beach system. Most sediment movement occurs underwater on the shoreface, a narrow, relatively steep surface seaward of the low tide line (fig. 1.2). This energetic zone extends offshore to deeper water where waves and currents generally do not move sediment. The width and depth of the shoreface vary along the coast, depending on wave climate, sediment supply, and the nature of the underlying geology. The overall shape of the beach/shoreface system changes seasonally as eroded sediment is stored offshore during stormy weather and later returned to the beach in fair weather.

The rates of shoreline retreat and the responses of a beach to storms largely depend on the geologic framework of the shoreface that is being excavated by ocean processes. Coastal engineers who design stabilization or nourishment projects typically assume that the shoreface is a pile of loose sediment with a uniform grain size. In their forecasts of beach behavior, waves acting on this idealized shoreface produce a predictably smooth, concave-up profile of equilibrium that retains its general shape as the shoreline changes position (Dean, 1991; Thieler and others, 2000a). In South Carolina, however, framework components beneath the shoreface widely differ in their resistance to erosion. Assuming that physical and biological processes are uniform across the region, we can reasonably expect a greater rate of change where less resistant materials (that is, loose sandy sediment) underlie the shoreface (Park and others, 2009). Conversely, a section of coast underlain by more resistant materials (that is, sedimentary rock) is likely to be relatively stable.

\subsection{Beaches on the Move}

Shoreline change over different time scales is quantified by comparing a series of maps, aerial photographs, or physical surveys made months, years, or decades apart (fig. 4.1). The measured shoreline has been variously defined as a specific contour elevation (that is, mean high water), a wet-dry line visible on aerial photographs, or a surveyed crest of the primary dune. Lateral movement of a shoreline over a specified period of time is typically shown as a series of colored-coded bands on a map (fig. 4.2A). Maps of this type reduce a complex coastal system to a single line when, in fact, the active beach covers a broad zone that extends a distance both landward and seaward of the shoreline. Accurate data are difficult to collect from submerged parts of the beach system where waves and currents are energetic. Most landbased surveying techniques end in shallow wading depths of about $1.5 \mathrm{~m}$, and marine-based surveys stay well offshore of the surf zone where ships can safely navigate. As a result, considerable areas of the active beach are poorly represented in most coastalerosion studies. Early studies typically provided only long-term trends because they relied on sparse data generated over many years. Beach profiles were collected more often, usually once or twice per year, but localized areas of high erosion rates commonly went undetected in gaps between widely spaced profiles.

Rates of shoreline change have varied widely along the Grand Strand since the middle of the 19th century (Hubbard and others, 1977a, 1977b; Anders and others, 1990; Morton and Miller, 2005). To quantify these changes better, the SCCES compiled several sources of data into a geographic information system (GIS). Paper maps originally produced by Anders and others (1990) were digitized and rectified to provide shoreline positions from 1851 to 1983. Shorelines determined from annual airborne topographic surveys (see Section 2) between 1996 and 2000 were provided by NOAA. Shoreline-change rates were calculated over two time scales, historical and short term (fig. 4.2). Mainland-attached beaches have remained relatively stable, with rates of retreat generally less than $0.5 \mathrm{~m} / \mathrm{yr}$. Barrier islands, however, have undergone large shifts in shoreline position, especially deposits in the vicinity of tidal inlets because they commonly migrate along the coast in response to longshore currents. Inlet migration causes alternating periods of accretion and erosion on the ends of adjacent barrier islands. In addition, new inlets open and old inlets close over time. Moving landward and seaward at rates up to $10 \mathrm{~m} / \mathrm{yr}$ since the $1850 \mathrm{~s}$, segments of shoreline adjacent to large inlets (North, Murrells, and Little River Inlets) have changed the most. Because of this dynamic process, construction and other activities planned for areas adjacent to inlets are managed differently by the State than activities in areas not influenced by inlets (see Section 1, Box \#3). 


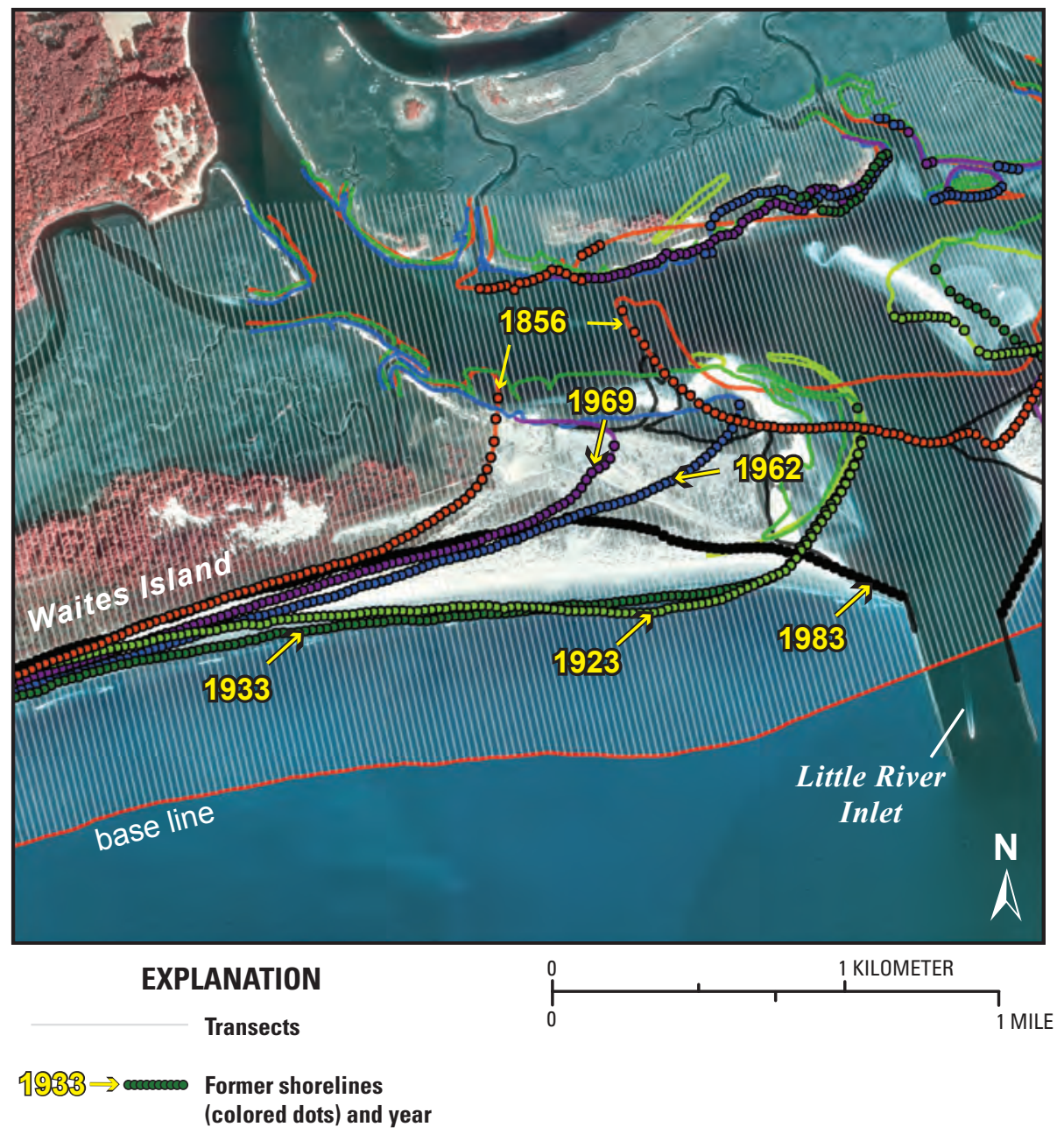

Figure 4.1. Aerial photograph showing historical shorelines from 1856 to 1983 around Waites Island and Little River Inlet. Shore-normal transects (gray lines), starting at a base line $500 \mathrm{~m}$ offshore (red line) and extending inland for 2,000 m, were drawn every $25 \mathrm{~m}$ along the coast. Where a transect intersected a former shoreline position (colored dots), the distance from the base line was used to calculate the average rate of shoreline change over that time period. See figure 4.2 for location. 


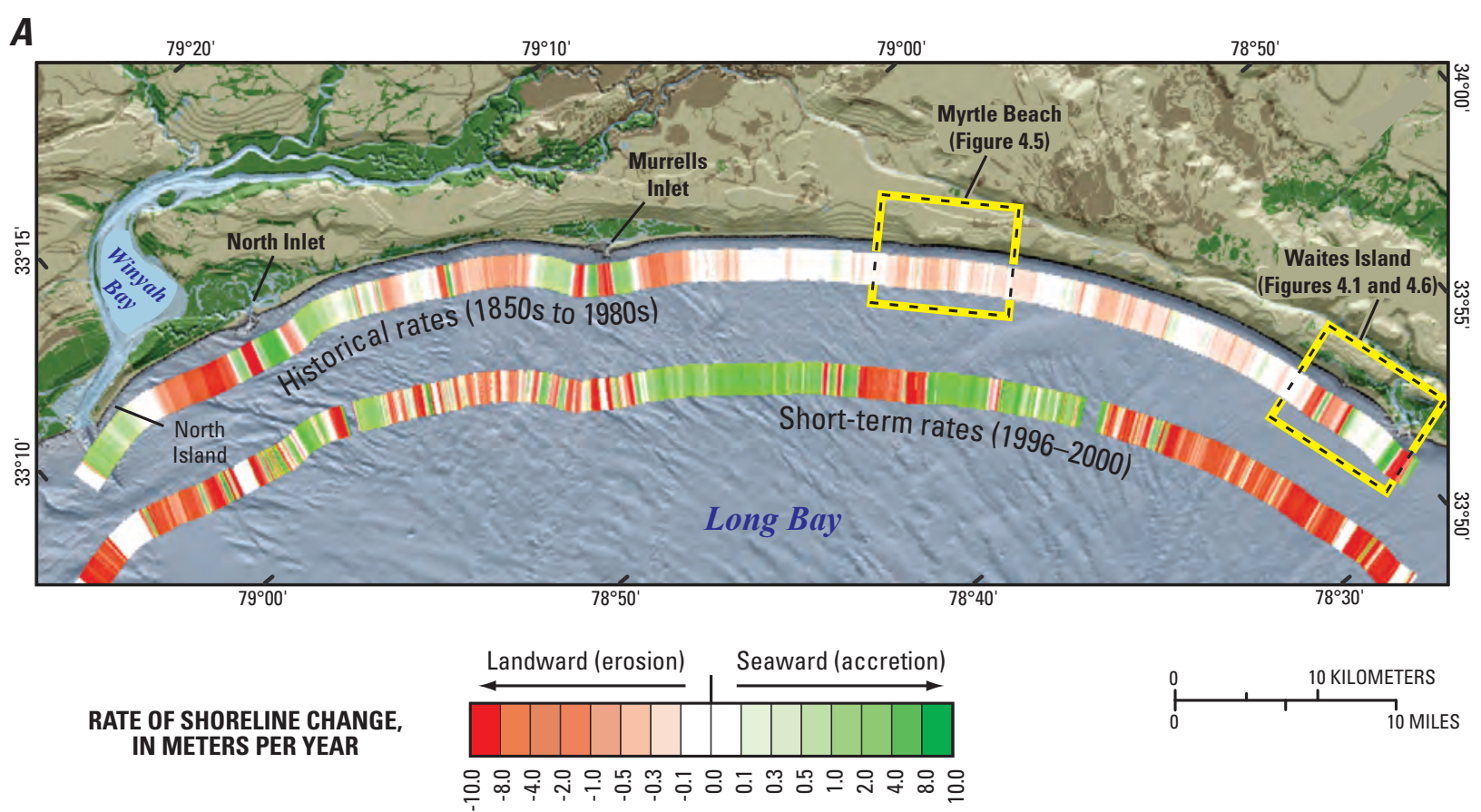

Figure 4.2. (A) Map view of the Grand Strand showing rates of shoreline change as color-coded bands parallel to the coast. Historical rates were based on shoreline positions derived from maps, charts, and air photographs. Short-term rates were based on shoreline positions measured by LIDAR surveys. Rates were calculated by using the linear rate-ofregression method (Thieler and others, 2003), which runs a best-fit line through all available data points. (B) Graph showing historical rates of shoreline change (green line) from the 1850s to 1980s. Highest rates of change were in the vicinity of inlets; lowest rates were along mainland-attached beaches. Standard error (red line) of the measurements indicates variability in shoreline positions through time. If the shoreline at a particular area shows high variability (that is, it moves back and forth a lot), standard error is high. Shoreline positions have higher variability along inlets and barrier islands, and lower variability along mainland-attached beaches. (C) Graph showing short-term rates of shoreline change between 1996 and 2000. Shoreline positions along smaller inlets, swashes, and the beach nourishment project at Myrtle Beach show the largest amount of variation at this time scale. 

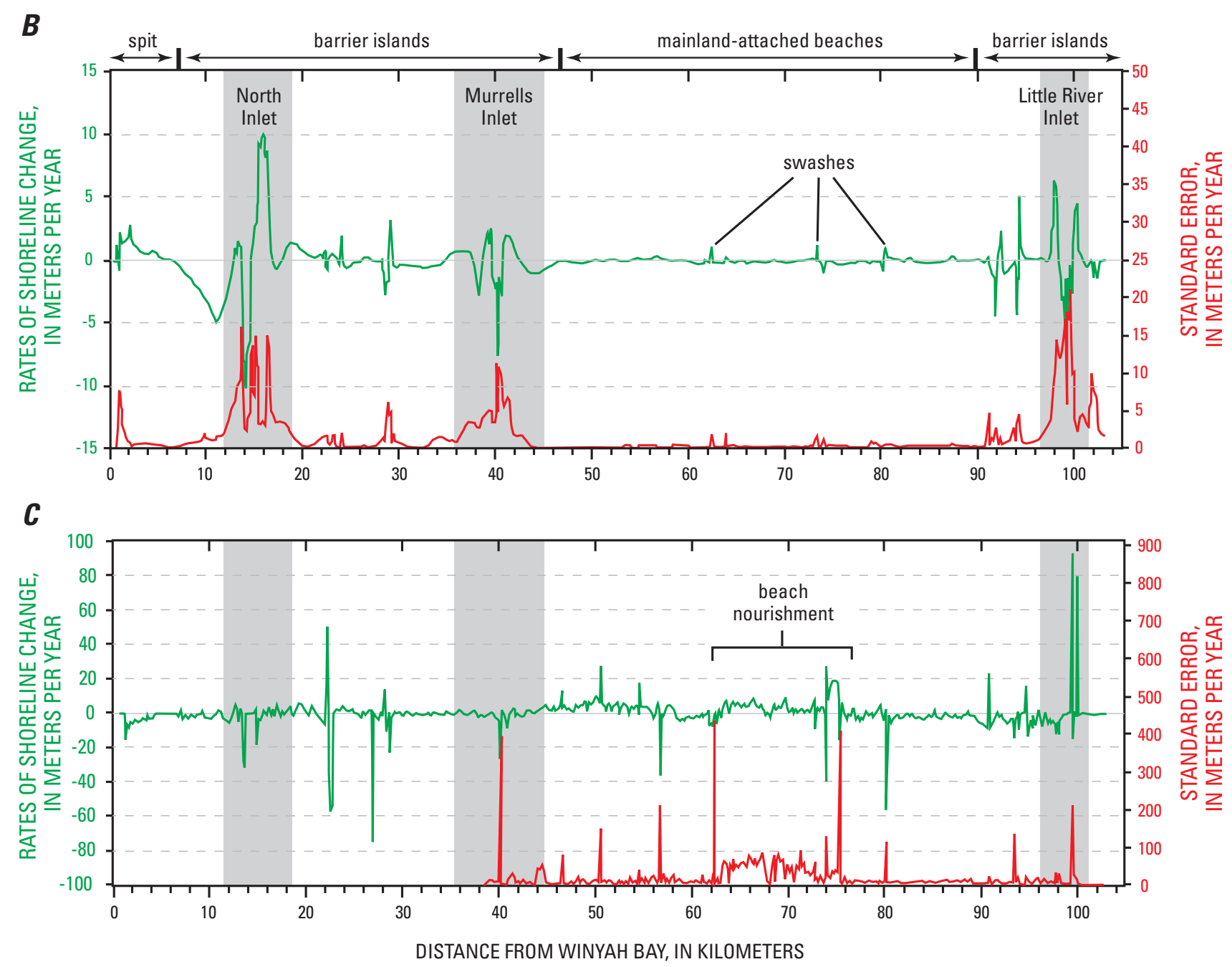


\subsection{Monitoring South Carolina's Beaches}

In 1993 the USGS, OCRM, and SCSGC formed a cooperative program to survey beaches statewide. The program, named Project BERM (Beach Erosion Research and Monitoring), has developed new methods to document change across the entire active beach (see figure 1 and Section 2.3). Frequent surveys (up to four times per year at selected locations) of beach shape have revealed short-term fluctuations that aid in constructing a record of seasonal and chronic changes. The ongoing program has continued to characterize the coast on a regional scale through at least 2008. More information on shoreline change can be found at the Project BERM web site http://www.coastal.edu/cmws/berm/index.html.

Beach profiles vary in shape along the length of the Grand Strand, largely depending on the volume of sediment available in a particular location. Beaches with little sediment exhibit steeper, more irregular profiles relative to beaches with abundant sediment. Representative profiles at two sites were chosen to illustrate the differences in profile shape:

1. Along the central Grand Strand at Myrtle Beach, the beach system is sediment limited. Older rocky deposits are exposed as ledges and scarps that create subtle relief on the shoreface. The beach profile is relatively steep, and water depths are more than $6 \mathrm{~m}$ at a distance of $342 \mathrm{~m}$ offshore of the $+1-\mathrm{m}$ contour (fig. 4.3A).

2. Along the northern Grand Strand at Waites Island, the beach system contains abundant loose sediment. Sediment shoals near the ends of the island are related to Hog and Little River Inlets. The beach profile is less steep than at Myrtle Beach, and water depths are about $6 \mathrm{~m}$ at a distance of $849 \mathrm{~m}$ offshore of the +1 -m contour (fig. 4.3B).

Average rates of shoreline retreat from the 1850s to the $1980 \mathrm{~s}$ are $0.2 \mathrm{~m} / \mathrm{yr}$ at the site of the Myrtle Beach profile and $0.9 \mathrm{~m} / \mathrm{yr}$ at the Waites Island profile (fig. 4.2). Even though long-term shoreline movement has been relatively slow, profiles collected 14 years apart show that more rapid changes are occurring in shallow submerged areas adjacent to the beach (fig. 4.3). The lower shoreface at Myrtle Beach, measured at the 6-m depth contour, has migrated landward at an average rate of $0.8 \mathrm{~m} / \mathrm{yr}$. At Waites Island, the 5-m depth contour has migrated landward at an average rate of $2.3 \mathrm{~m} / \mathrm{yr}$. As a result, nearshore water depths at these locations are slowly increasing, and beach profiles are becoming steeper over time. Steepening at Myrtle Beach can be attributed to beach nourishment pushing the upper profile seaward and erosion driving landward migration of the lower shoreface, albeit slowed by the presence of hard rocky substrate. The cause of steepening at Waites Island is not known but might be related to sediment trapping by jetties at Little River Inlet. Whatever the cause, as water depths in front of a beach increase, wave impacts on the shoreline also increase.

\subsection{Framework Controls on Beaches}

Grand Strand beaches sit on top of a framework of layered sedimentary rocks, which have been deeply eroded over the last few million years (see Section 3). The upper surface of these units is widely exposed on the shoreface and inner shelf, especially offshore of mainland-attached beaches in the central part of the study area. The erosion-resistant materials lie at shallow depths beneath the region's beaches (fig. 4.4A) and provide firm foundations for high-rise buildings. Outcrops of cemented beach deposits are also sporadically exposed and buried by movement of modern beach sands at Hurl Rock Park in Myrtle Beach (fig. 4.4B). Near tidal inlets in the northern and southern parts of the Grand Strand, however, thicker deposits of modern sediment completely bury the rocks.

The shoreface profile and stability of beaches over time are very different where sediment is abundant, such as Waites Island, relative to areas where sediment is scarce, such as Myrtle Beach. The following sections describe representative examples of sediment-limited and sediment-rich areas of the Grand Strand. In these two examples, the relative abundance of modern sediment on the shoreface determines the overall shape of adjacent beaches and local rates of coastal erosion. 


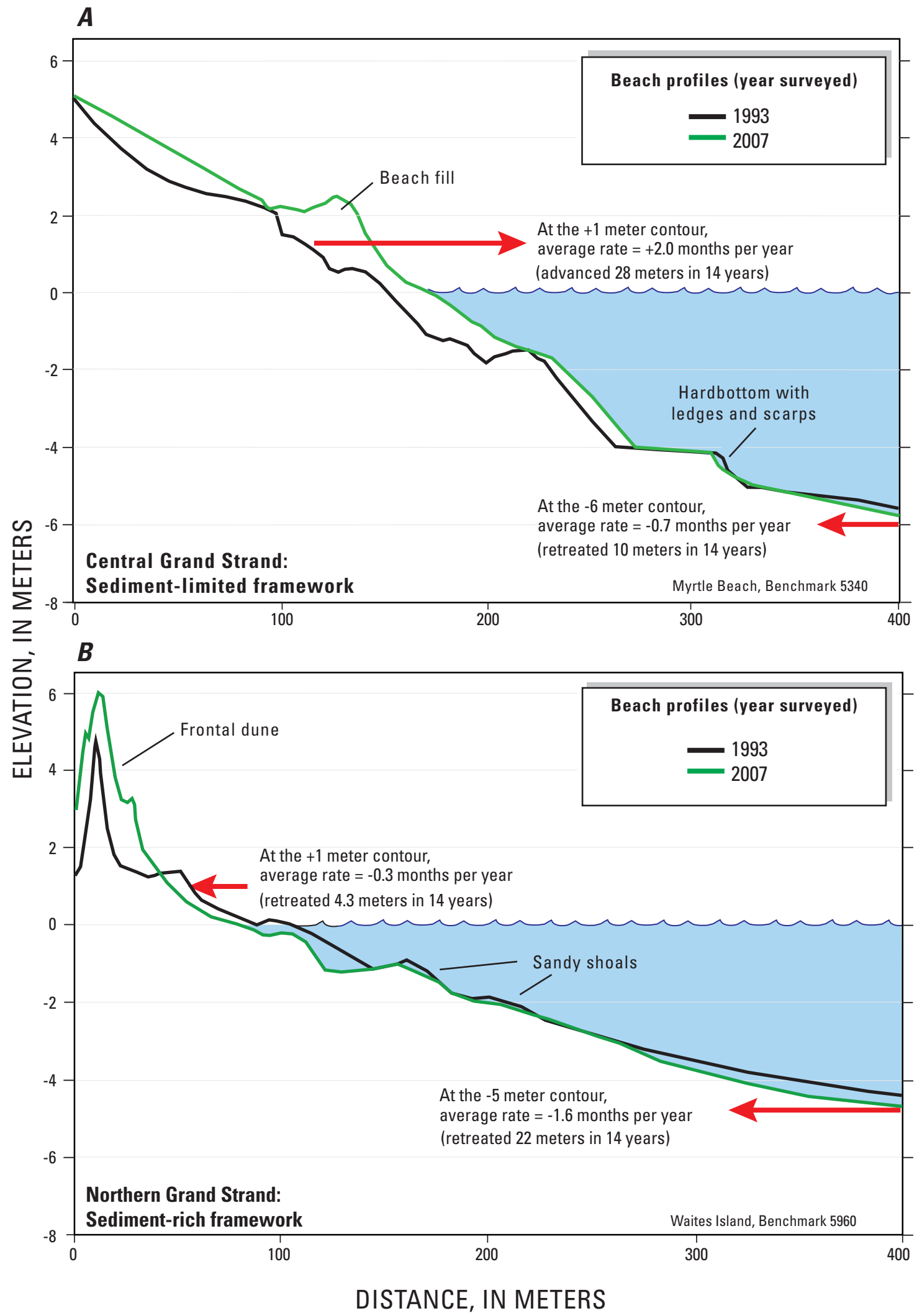

Figure 4.3. (A) Typical profile at Myrtle Beach is relatively steep and interrupted by rocky ledges and scarps. This area was nourished in 1998, and a small wedge of beach fill remains visible in the 2007 profile. (B) Typical profile at Waites Island is more gently sloping because of abundant sand associated with inlet shoals. The profile has steepened in both locations because of continued erosion and landward migration (that is, retreat) of the middle to lower shoreface (red arrows). See figures 4.5 and 4.6 for locations of the profiles. 
Central Grand Strand: Sediment-Limited

\section{Framework}

The central part of the Grand Strand, occupied in part by the City of Myrtle Beach, is one of the longest stretches of seaboard that is not protected by barrier islands in the eastern United States. For a distance of more than $50 \mathrm{~km}$, open-ocean processes act directly on the mainland. Landward of the beaches, adjacent upland elevations rise quickly to more than $10 \mathrm{~m}$ above local mean sea level, putting most of the city above the flood zone. Average rates of shoreline change in this area are relatively low, except around swashes where the shoreline is migrating across small fluvial valleys that drain the adjacent upland (fig. 4.2B). The relative stability of the Myrtle Beach coastline is largely controlled by sedimentary rock and erosion-resistant deposits of ancient shorelines that underlie the area.

The central Grand Strand area represents an endmember shoreline segment where older sedimentary rocks dominate the shoreface. Offshore of Myrtle Beach, the shoreface is characterized by a series of low-relief scarps and ledges formed by layers of rock exposed at the seafloor. Subbottom profiles collected along the beach just seaward of the surf zone show that rocks also compose the shallow subsurface (fig. 4.5, profiles A-D). The shape and position of the beach and shoreface change relatively little in areas where modern processes act on these erosion-resistant deposits. This area has exhibited only modest changes in beach profile during large erosional events such as Hurricane Hugo in 1989 (Nelson, 1991) and during the years following such storms (fig. 2.8). The most significant change resulted from a regional beach-nourishment project in 1997 that pumped large amounts of sediment from borrow sites offshore onto the beach. At that time (prior to the SCCES), little information on the location and volume of offshore sediment resources was available to guide dredge operations. Instead of hitting soft sediment, dredges often scraped rocky parts of the seafloor even though large deposits of high-quality sand existed nearby.
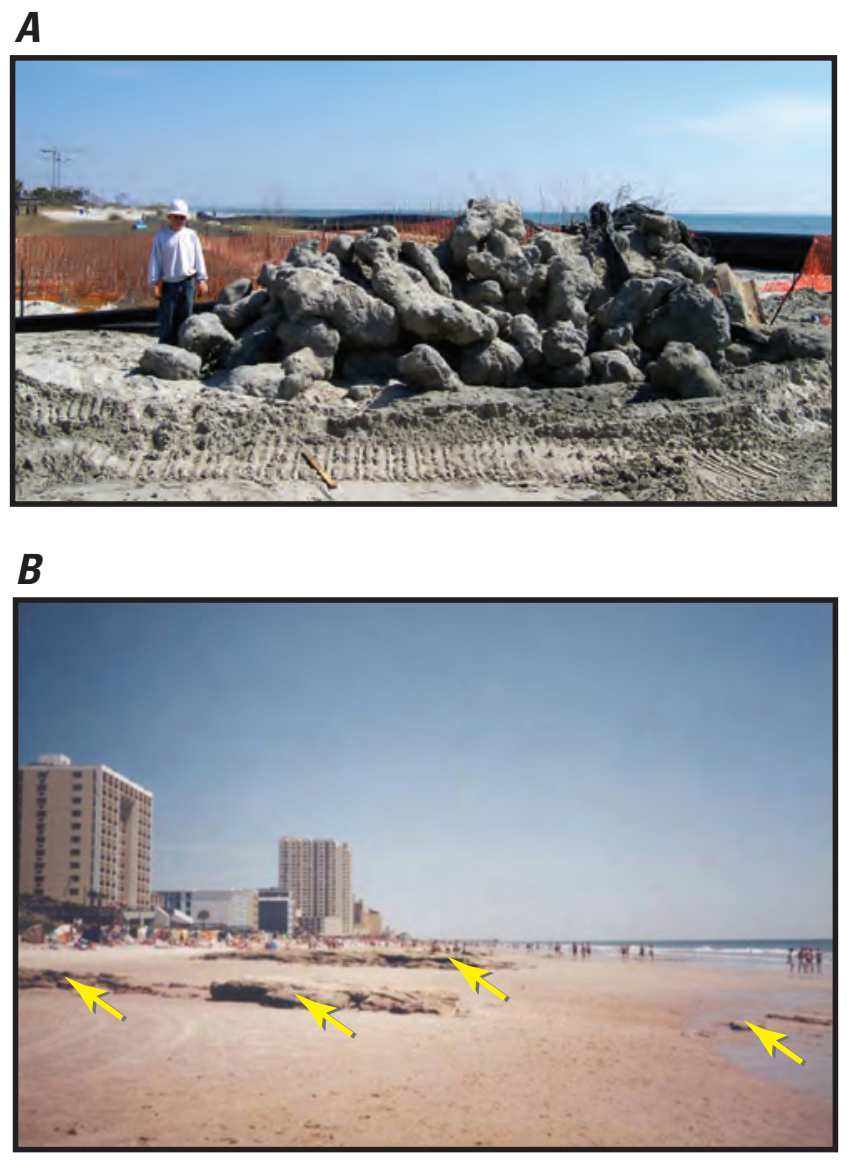

Figure 4.4. (A) Large boulders excavated during construction of stormwater outfall near 52nd Avenue North, Myrtle Beach (published by permission of James Daigle, Sunland Construction, Inc., Eunice, Louisiana). The boulders came from rocky deposits at shallow depths beneath Grand Strand beaches. (B) Rocks indicated by arrows exposed by beach erosion at Hurl Rock Park, Myrtle Beach (published by permission of Paul Gayes, Coastal Carolina University, Conway, South Carolina.) Sediment removed by storms typically returns in times of fair weather and rebuilds the beach. 

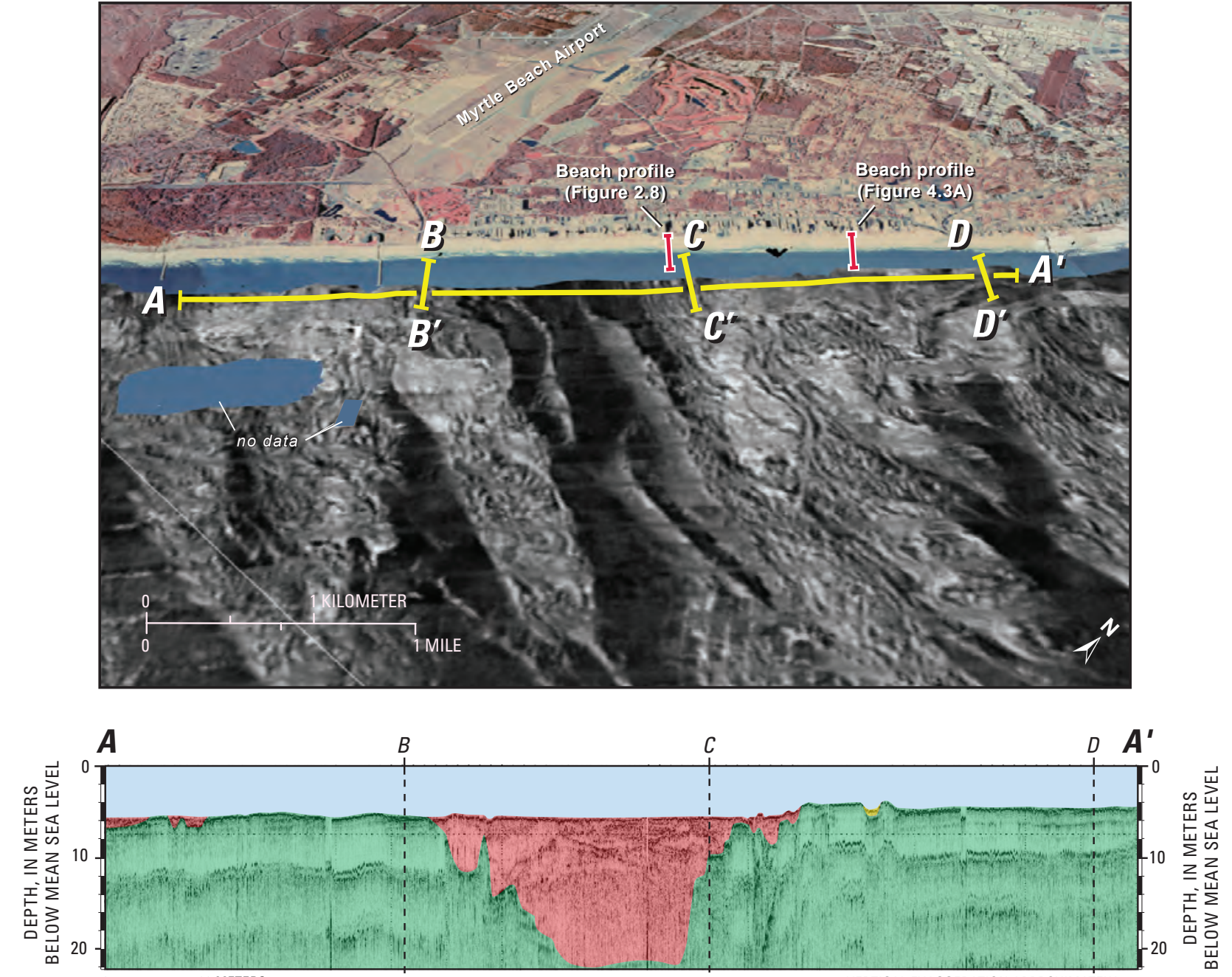
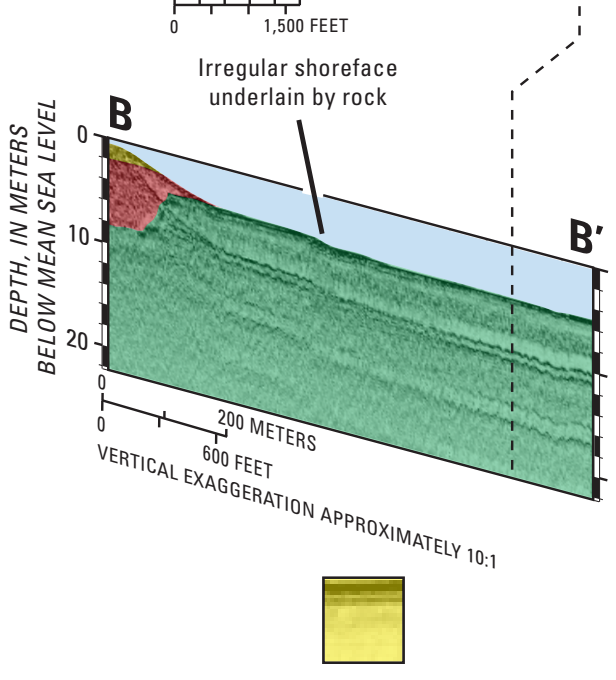

Modern sediment (less than 10,000 years old)

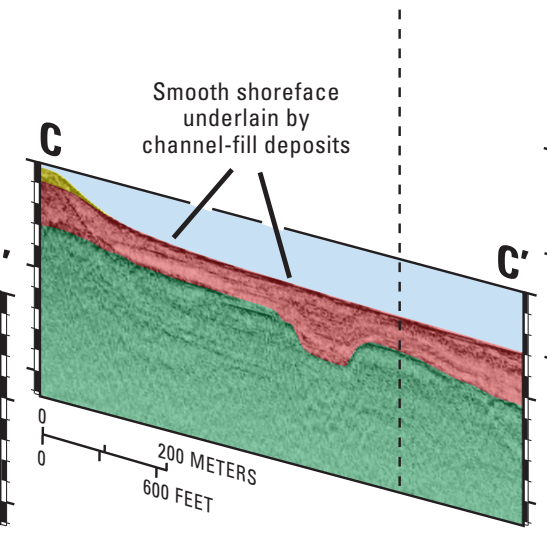

EXPLANATION

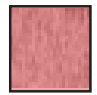

Channel-fill deposits (1.8 million to 10,000 years old)

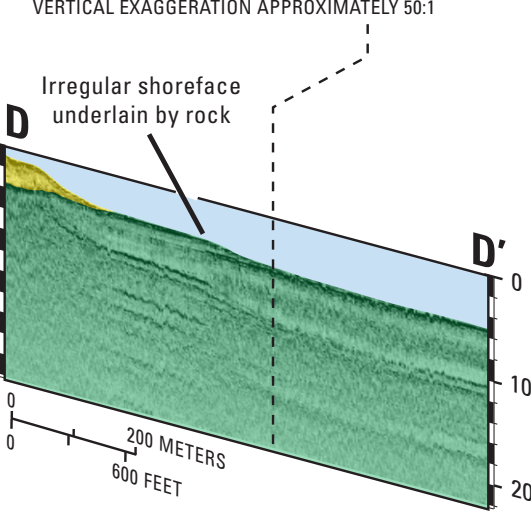

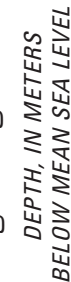

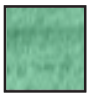

Sedimentary rock (approximately 70 million years old)

Figure 4.5. Shoreface geology along the central Grand Strand at Myrtle Beach. Perspective view shows a complex pattern of acoustic backscatter on the shallow seafloor (top). High backscatter (light shades) generally indicates coarse sand, gravel, and rock. Low backscatter (darker shades) generally indicates sandy or muddy sediment. Interpreted subbottom profiles A-A', B-B', C-C', and D-D' show the geologic framework underlying the shoreface. See figure 4.2A for location. 
Low-relief rocky outcrops do not characterize the entire shoreface of the central Grand Strand. In some areas, the cross-shore beach profile is much smoother and steeper than in adjacent rocky areas; the smooth profiles coincide with the locations of ancient river channels eroded into older sedimentary rocks (fig. 4.5, profile C). Deposits filling the channels are younger, relatively weaker, and therefore less resistant to erosion than sedimentary rock. The smooth, steeply sloping shoreface reflects the relative ease by which channel-fill deposits can be eroded by waves and currents.

\section{Northern Grand Strand: Sediment-Rich Framework}

At the northern and southern ends of the Grand Strand, barrier islands have formed instead of the mainland-attached beaches that characterize the central section. Waites Island, at the northern end (fig. 4.2A), is the first in a chain of small barrier islands that extend north along the coast of Long Bay to Cape Fear, North Carolina. Sandy barriers of similar shape and size also extend south from Garden City to Winyah Bay. As is typical for barrier islands, their shape and behavior are strongly influenced by waves hitting the beach and tidal currents moving in and out of inlets.

Unlike areas closer to the center of the Grand Strand, the shoreface and inner shelf along Waites Island contain abundant sand. Erosion-resistant sedimentary rocks are more deeply buried by Holocene sediment at this location (fig. 4.6). The shape and position of the shoreline are strongly modified by storage of modern sediment in tidal shoals associated with Little River and Hog Inlets. The inlet-related sand bodies are up to $6 \mathrm{~m}$ thick and together represent one of the largest accumulations of modern sediment along the coast.

The shoreface along Waites Island generally forms a smooth concave-up profile, the characteristic shape of beaches with abundant mobile sediment (fig. 4.3B). Along most of the island, significant amounts of sediment have accumulated in the upper beach system. Beach ridges have expanded seaward over the last 20 years, probably because of jetty construction at Little River Inlet. Sediment captured by the jetties has accumulated along the north end of the island. The mid-to-lower shoreface, however, has not grown seaward in the same way as the upper beach. Measured at a depth of $5 \mathrm{~m}$, the shoreface has progressively migrated landward, thereby creating a steeper slope over time.

\subsection{Exposure and Burial of Hardbottom Areas}

Sediments that compose the shoreface of the Grand Strand vary in thickness and constantly shift across an irregular, rocky surface. In the short term, fair-weather conditions promote landward transport of sediment from the lower shoreface to the upper shoreface and beach system. The wide, elevated berm formed by these mobile sediments remains dry at mean high tide and is a favorite spot for beachgoers. Just offshore, however, sediment is scarce, and rock is exposed on the shallow seafloor (fig. 4.7). Erosion of these exposed hardbottoms provides relatively small but significant quantities of new sediment that is incorporated in the active beach (Riggs and others, 1998). Over the long term, repeated cycles of exposure wear down the erosion-resistant rocks of the shoreface and effectively increase water depths just offshore of the beach.

During storms, waves and currents remove sediment stored in the dunes and beach and transport it offshore (fig. 4.7). The seasonal movement of sediment away from the beach temporarily buries the hardbottom areas on the shoreface. Stripped of sediment cover, the rocks on the upper shoreface are eroded and contribute some new sediment to the active beach. When fair weather returns, sediment on the shoreface is driven back onto the upper shoreface and beach, reestablishing the berm and dunes. This onshore-offshore shifting of sediment alternately buries and exposes rocks on the beach and shoreface. The balance of this process, along with gains and losses from longshore transport, determines whether there is erosion or accretion of a particular stretch of beach. As a result of this constant shifting, the beach and its underlying rocky foundation wear away, and the beach and shoreface migrate landward as a system. 

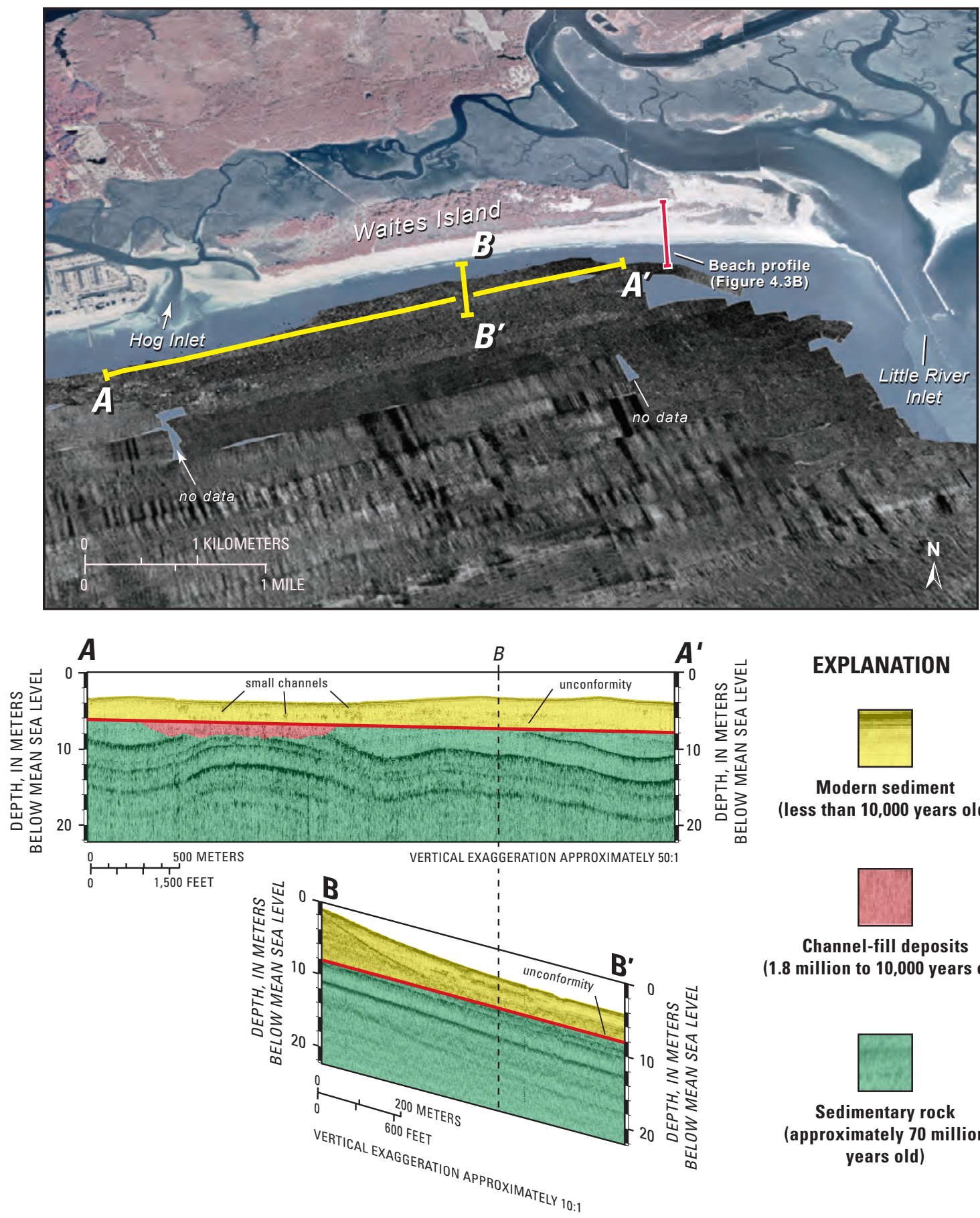

EXPLANATION

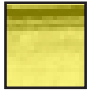

Modern sediment (less than 10,000 years old)

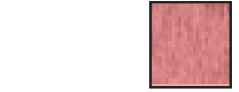

Channel-fill deposits (1.8 million to 10,000 years old)

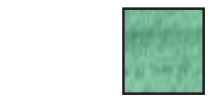

Sedimentary rock (approximately 70 million years old)

Figure 4.6. Shoreface geology along the northern Grand Strand at Waites Island. Perspective view shows a complex pattern of acoustic backscatter on the shallow seafloor (top). High backscatter (light shades) generally indicates coarse sand, gravel, and rock. Low backscatter (darker shades) generally indicates sandy or muddy sediment. Interpreted subbottom profiles $A-A^{\prime}$ and $B-B^{\prime}$ show the geologic framework underlying the shoreface. See figure 4.2A for location. 


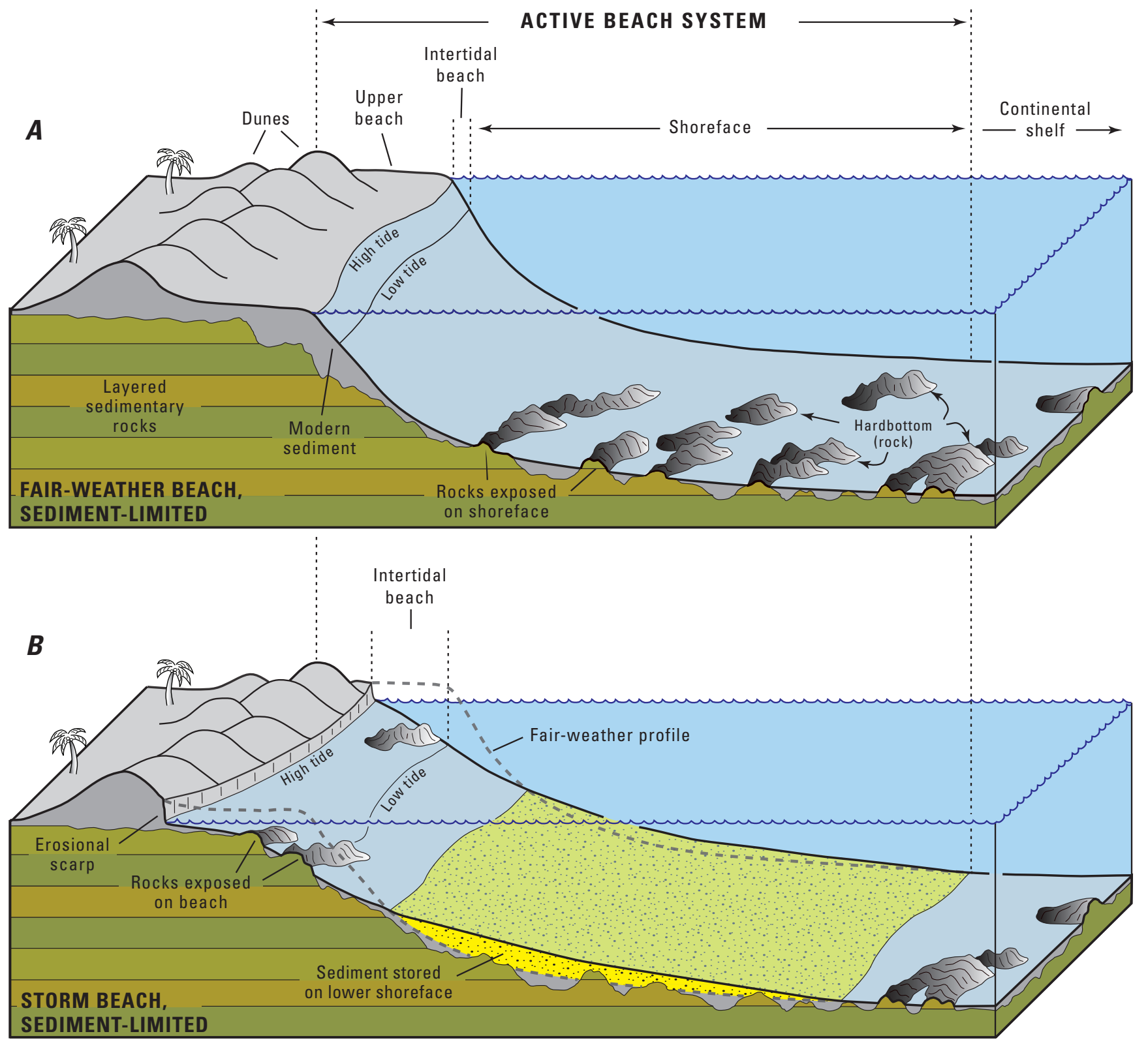

VERTICAL SCALE GREATLY EXAGGERATED

Figure 4.7. Seasonal changes in a sediment-limited beach typical of the central Grand Strand. (A) During times of fair weather, sediment is transported landward from the shoreface and stored in the dunes and berm. Upper surface of erosion-resistant sedimentary rock is exposed in shallow-water areas adjacent to the beach. (B) During times of stormy weather, the beach is eroded, and sedimentary rock is locally exposed on the broad intertidal beach. The eroded sediment is transported offshore, where it buries rocky areas and produces a relatively smooth, sandy shoreface. 


\subsection{Summary}

The uniquely detailed record of shoreline behavior from the SCCES provides guidance for land-use and development decisions along the Grand Strand. It also helps us understand the linkages between subaerial coastal lands, which may be eroded in the near future, and adjacent submerged lands of the continental shelf where sediment moves freely on, off, and along the shore. As the beach and shoreface migrate, they contact different materials underlying the modern coastal system. The degree of resistance of the materials to erosion depends on their composition (percent sand, silt, clay) and mechanical properties (degree of cementation or compactness). Erosion proceeds at different rates; less resistant deposits are eroded more deeply, and more resistant deposits are eroded less deeply. This differential erosion has modified the morphology of the seafloor and, in some cases, probably altered sediment-dispersal pathways in nearshore areas. Because extensive development is located very near the coast throughout the region, even minor rates of coastal erosion pose a serious threat. The large number of engineered coastalstabilization structures along the Grand Strand is a testament to the pervasive erosion, and the distribution of these structures provides a general indication of the areas where the effects have been the greatest. In many instances, these so-called hard engineering solutions (fig. 1.7) have proven to further exacerbate erosion rather than alleviate the problem. 


\subsection{Introduction}

$\mathrm{T}$ he constant shifting of sediment along shorelines presents a fundamental challenge for the prediction of beach behavior. A valuable approach to managing coastal resources is to consider the sediment that moves in and out of or is stored within a beach system in an annual sediment budget (Komar, 1996). A balanced sediment budget means that, over time, equal amounts of sediment are transported into and out of a coastal compartment. Ideally, annual losses are offset by annual gains, and the beach remains relatively stable; however, an imbalance in the amount of sediment gained or lost during the year destabilizes the beach and causes changes in its shape and (or) position.

A good way to think of a sediment budget is in terms of a bank account: when more sediment is deposited than removed, the sediment budget has a surplus and the beach grows seaward. Conversely, when more sediment is removed than deposited, the sediment budget is in deficit and the beach retreats landward. Coastal erosion occurs when waves and currents remove sediment faster than it can be replaced. If a beach has a large positive balance of sediment, a small deficit will have a minor impact on its overall condition; however, if the initial balance is small (that is, the beach system stores little sediment), relatively minor losses can cause significant changes in the shape and/or position of the beach.

The major components of a sediment budget are sources that provide new sediment, sinks where sediment is lost to the active beach, and transport pathways along which sediment is exchanged between different parts of the coastal system (fig. 5.1). Sediment budgets typically are based on limited data that

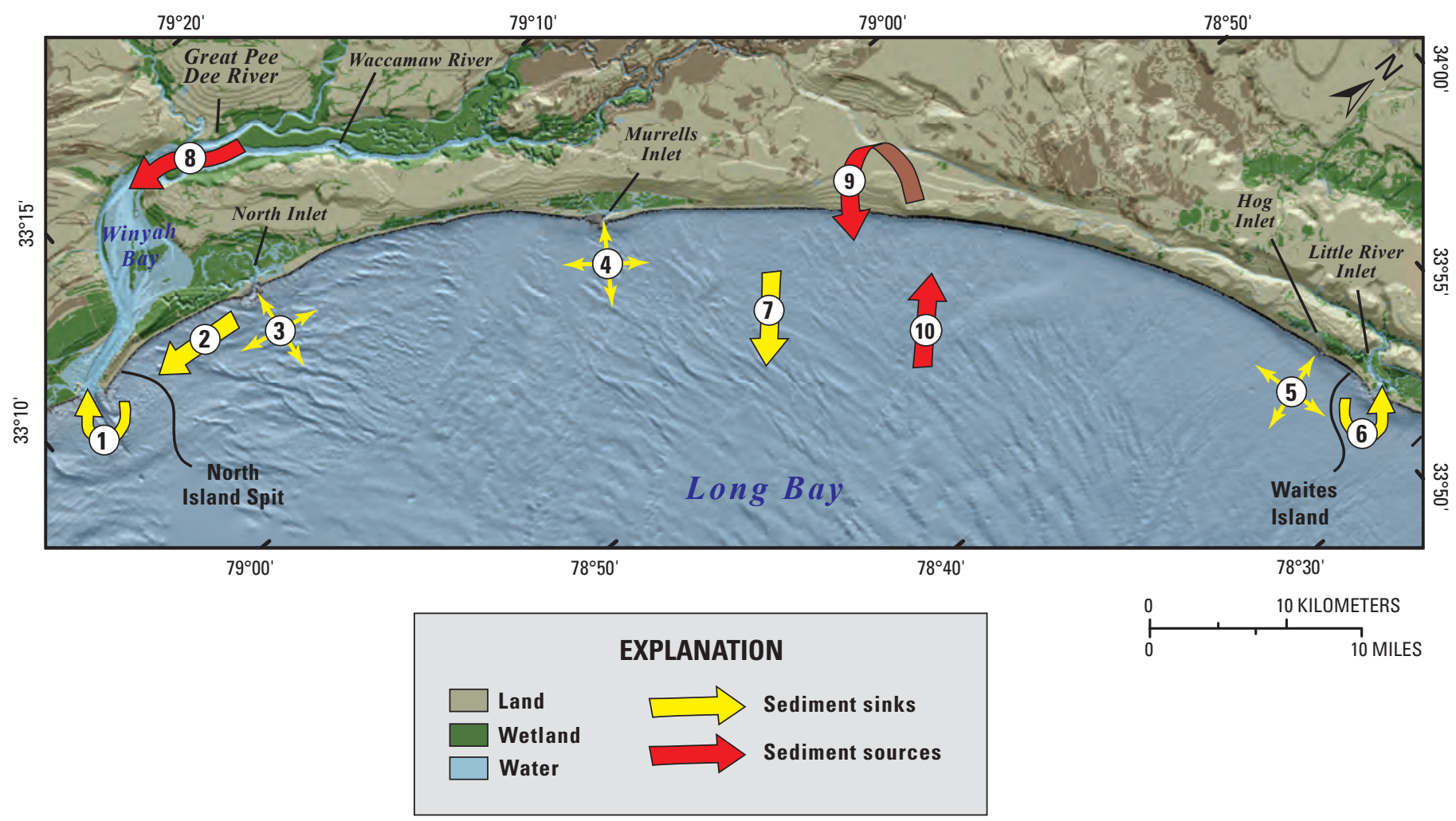

Figure 5.1. The components of a conceptual long-term sediment budget for the Grand Strand region (modified from Gayes and others, 2003). Numbered arrows indicate the general direction of sediment movement. Sediment sinks include: 1. Winyah Bay, 2. North Island Spit, 3. North Inlet, 4. Murrells Inlet, 5. Hog Inlet, 6. Little River Inlet, and 7. loss offshore. Sediment sources include: 8. rivers, 9. beach and shoreface erosion, and 10. inner-shelf erosion. See table 5.1 for estimates of sediment volumes associated with each component. 
include inherent uncertainties. Accurate estimates of sediment gains and losses are difficult to determine, particularly along coasts with numerous sources and sinks. The Grand Strand, however, is a sedimentlimited system that is relatively free of complications associated with inlets and estuaries. It provides an unusual opportunity to determine a first-order approximation of sediment losses and gains (table 5.1) and to identify transport pathways within a relatively simple coastal compartment. This section incorporates some text previously published by Gayes and others (2003) with new data and figures to provide an overview of sediment movement in the region.

\subsection{Sediment Sources}

Sediment in the active beach system is derived from (1) erosion of upland by rivers, (2) longshore transport from adjacent coastal compartments,

(3) erosion of older beach and shoreface deposits, and

(4) erosion of older deposits on the inner shelf. The sum of the deposits from all of these sources represents the input of new sediment into the active beach system. Although the amounts of sediment contributed by the sources are difficult to quantify accurately, we provide a general accounting of their contributions.

\section{Sediment Delivered by Rivers}

Fluvial input to the coastal system is limited to areas at the northern and southern boundaries of Long Bay. In the north, the Cape Fear River enters Long Bay at Cape Fear. In the south, the Great Pee Dee River coalesces with several smaller rivers near Georgetown to form a large estuary at Winyah Bay. Dams on these rivers largely block the movement of sediment, however, and most of the sediment that does makes it downstream is trapped in Winyah Bay before it reaches the coast (Meade and Trimball, 1974; Patchineelam and others, 1999). Extensive deposits of mud are dredged routinely to maintain shipping channels in upper parts of Winyah Bay and the Cape Fear River estuary. The limited amount of fluvial sediment that is transported beyond the estuaries appears to be incorporated into shoal complexes offshore of Cape Fear and Cape Romain.

Table 5.1. A conceptual sediment budget for the Grand Strand region.

[Table lists estimated volumes of mobile sediment lost annually to sinks and gained from different sources (modified from Gayes and others, 2003). Numbers in first column correspond to numbered arrows in figure 5.1. Dredging records are from C. Mack (U.S. Army Corps of Engineers, oral commun., 2003)]

\begin{tabular}{lcl}
\multicolumn{1}{c}{$\begin{array}{c}\text { Sediment sinks } \\
\text { (losses) }\end{array}$} & $\begin{array}{c}\text { Volume } \\
\text { (cubic meters per year) }\end{array}$ & \multicolumn{1}{c}{ Basis of estimate } \\
\hline $\begin{array}{l}\text { 1. Winyah Bay } \\
\text { 2. North Island Spit }\end{array}$ & 284,000 & 1994-2002 dredging records \\
3. North Inlet & 79,000 & Historic spit growth \\
4. Murrells Inlet & $?$ & \\
5. Hog Inlet & 75,000 & 1974-1978 dredging records \\
6. Little River Inlet & $?$ & \\
7. Loss offshore & 57,000 & 1982-1995 dredging records \\
\multicolumn{1}{c}{ Total sinks } & $?$ & \\
\hline Sediment sources & 495,000 & \\
\hline (gains) & & Patchineelam and others (1999) \\
\hline 8. Rivers & Very small & Beach-profile migration based on the long-term average erosion rate \\
9. Beach and shoreface erosion & 104,000 & Difference between total losses (1-7) and gains from other source (8-9) \\
10. Inner-shelf erosion & 391,000 & \\
\hline$\quad$ Total sources & 495,000 & \\
\hline
\end{tabular}




\section{Sediment Delivered by Longshore Transport}

Geomorphic evidence suggests that little or no sediment is exchanged around the capes that separate Long Bay from coastal compartments to the north and south. Extensive southerly spit growth at the Winyah Bay entrance indicates a dominance of southerly longshore transport, which limits any contribution of sediment moving north into Long Bay. Sand spits and the associated shoal complex offshore of Cape Fear appear to be the dominant regional sediment sinks, which effectively trap sediment that might enter Long Bay from the north (Denison, 1998).

\section{Erosion of Beach and Shoreface Deposits}

The contribution of sediment from beach and shoreface erosion was estimated by analyzing beachprofile geometries and historical erosion rates (Gayes and others, 2003). First, the coast was divided into about 950 segments that measured $100 \mathrm{~m}$ wide and extended along the entire Grand Strand coastline (fig. 5.2). Each segment was assigned the closest BERM profile, which typically had been measured within $200 \mathrm{~m}$ of each segment. The assigned profile for each segment was translated landward according to the long-term erosion rate for that segment of beach. The translated profile was assumed to maintain a constant shape over the long term (decades or longer), although slight variations probably occurred over the short term (months to years). The crosssectional areas between the translated and existing profiles in each segment were calculated and added for all segments to represent the volume of sediment derived by this idealized migration. On the basis of this analysis, erosion of the beach and shoreface along the entire Grand Strand has released an average of $104,000 \mathrm{~m}^{3} / \mathrm{yr}$ of sediment. This volume of sand is a maximum estimate because deposits underlying large areas of the beach contain abundant muddy sediment, and its erosion yields relatively less sandsized sediment.

\section{Erosion of Inner-Shelf Deposits}

A considerable proportion of sediment in the modern coastal system is derived from the erosion of older materials underlying the inner shelf. Wehmiller and others (1995) provide evidence of this process by showing that up to 75 percent of clam shells found on beaches in the region are actually fossils. The clams lived more than 10,000 years ago and, after death, were preserved in rocky deposits that underlie parts of Long Bay. Biological and physical processes actively rework these deposits on the inner shelf, providing recycled sediment to the modern coast. Riggs and others (1998) calculated that bioerosion of hardbottoms in nearby Onslow Bay, North Carolina (fig. 1.3A), yields as much as $5.5 \mathrm{~kg} / \mathrm{m}^{2}$ of new sediment each year. Large waves can excavate fragments of the rocky material from the inner shelf and wash them up onto Grand Strand beaches (fig. 5.3). Soft corals and other invertebrates are often still attached to the rock fragments on the beach after storms. These types of organisms typically live more than $1 \mathrm{~km}$ offshore of the surf zone; in this offshore area, waves and sediment abrasion are less intense. Their presence on the beach indicates inner-shelf erosion and onshore transport during intense storms. The volume of sediment derived from the inner shelf is estimated as $391,000 \mathrm{~m}^{3} / \mathrm{yr}$. This value was indirectly calculated and represents the residual or remaining volume of sediment needed to balance the total losses in the budget (table 5.1).

The combination of processes that drive net onshore transport of sediment are not fully understood, but the estimated volume of inner-shelf sediment, at this regional scale, is not excessive. It represents only a fraction of the sediment that is available on the inner shelf as a potential source of beach sediment. On the basis of geologic mapping, at least 270 million $\mathrm{m}^{3}$ (353 million $\left.\mathrm{yd}^{3}\right)$ of mobile sediment is on the inner shelf (fig. 3.5B). This large reservoir of sediment can readily account for the deficit in the sediment budget. 


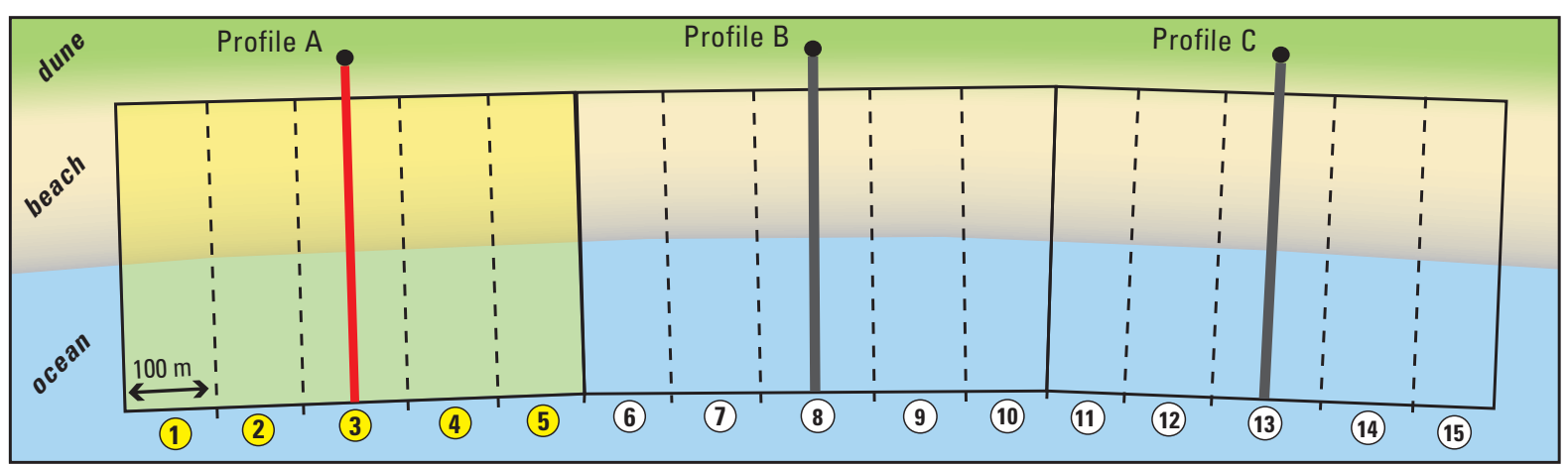

B

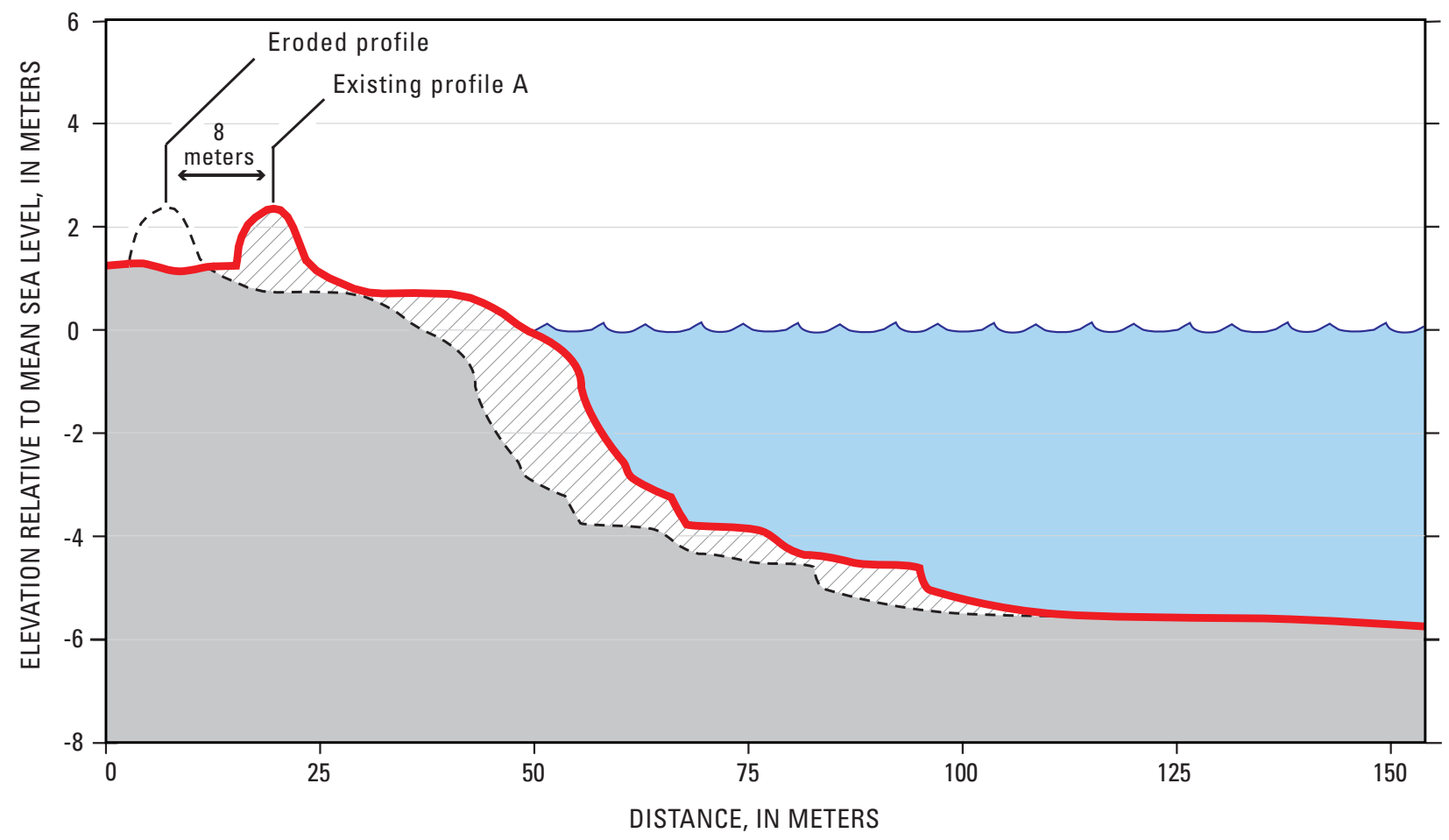

Figure 5.2. Diagrams showing how volumes were calculated for sediment eroded from beach and shoreface deposits. (A) Plan view of a beach divided into 15 equal segments, each $100 \mathrm{~m}$ wide and extending from the dune crest to the shoreface. A BERM profile $(A, B$, or $C$ ) is assigned to nearby segments of beach. In this example, profile $A$ (red line) represents segments 1 to 5 . Profiles $B$ and $C$ represent segments 6 to 10 and 11 to 15 , respectively. (B) The existing profile is moved landward based on the long-term erosion rate that has been established for each beach segment (fig. 4.2). The profile shape remains constant, and the area between the eroded profile and the existing profile represents the sediment released in one year. For example, if the beach in segment 1 is eroding rapidly at $8 \mathrm{~m} / \mathrm{yr}$, profile $A$ is translated $8 \mathrm{~m}$ landward of its original position, and the region between the two profiles (diagonal-line pattern) represents the annual area of eroded sediment. Values are added for all segments to determine the volume of new sediment that is contributed to the regional sediment budget. 


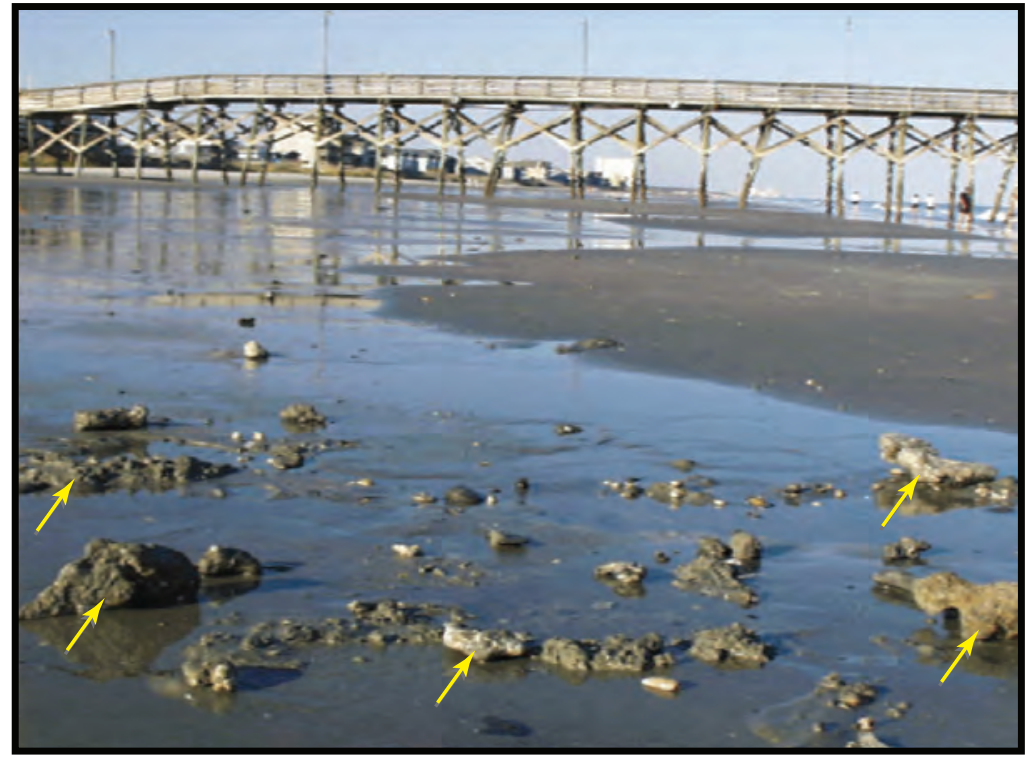

Figure 5.3. Pieces of sedimentary rock (arrows) on Surfside Beach after a 1999 storm. The corals attached to these rock fragments typically live more than $1 \mathrm{~km}$ offshore of the beach (from Gayes and others, 2003).

\subsection{Sediment Sinks}

On a regional scale, potential sinks for sediment from the beach system include adjacent coastal compartments, into which sediment is transported across the southern or northern boundary, and the inner shelf, to which sediment is transported from the shore. The sum of the sediment volumes lost into all of these sinks represents the total loss of sediment from the active beach system. Geologic mapping and analysis of dredging records provide estimates of the annual rate of sediment loss and information about transport pathways and probable sinks.

\section{Losses Across the Southern Boundary}

Significant sediment transport out of the Grand Strand is evident across the southern boundary at Winyah Bay. The bay lies behind North Island spit, a sandy peninsula about $5 \mathrm{~km}$ long and $1 \mathrm{~km}$ wide (figs. 5.1, 5.4A). Progressive elongation of the spit deflected the Winyah Bay entrance channel about $1 \mathrm{~km}$ to the south between 1872 and 1983 (Anders and others, 1990; Morton and Miller, 2005). The estimated volume of the spit deposits is about 9 million $\mathrm{m}^{3}$ on the basis of data from cores, ground-penetrating radar, and topographic surveys. Over the 111 years of observed spit growth, an estimated 79,000 $\mathrm{m}^{3} / \mathrm{yr}$ of sediment was lost from the Grand Strand (table 5.1).

Sandy sediment also fills the entrance channel to Winyah Bay, where a jetty system was constructed to stabilize and maintain the shipping lanes into the Port of Georgetown. Regular dredging is required to keep the channel open for navigation. Logs from maintenance-dredging projects completed between 1994 and 2002 indicate that the average annual rate of deposition in the channel and lower bay is $284,000 \mathrm{~m}^{3} / \mathrm{yr}$. Most of this material probably was delivered by southerly directed longshore transport in Long Bay (Patchineelam and others, 1999).

\section{Losses Across the Northern Boundary}

The results of studies by the U.S. Army Corps of Engineers (USACE) indicate that longshore transport is small and more variable across the northern boundary of Long Bay at Little River Inlet. On the basis of measurements recorded over short time periods, the initial modeling reported limited net annual transport towards the northeast out of the Grand Strand system (Chasten, 1992). Some of the northward-transported sediment apparently is accumulating at Waites Island. The formation of beach ridges indicates seaward growth of the island and a 
$\boldsymbol{A}$

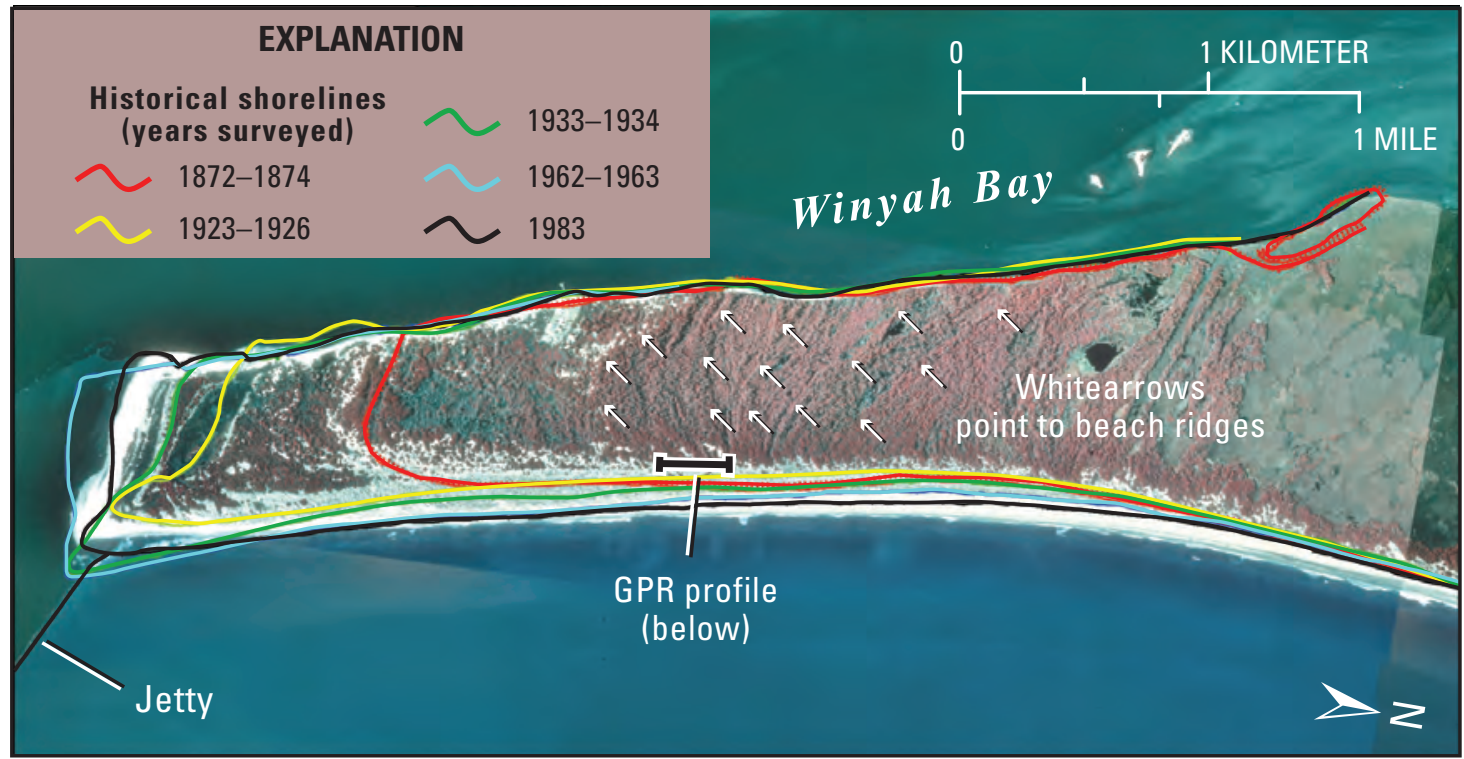

B

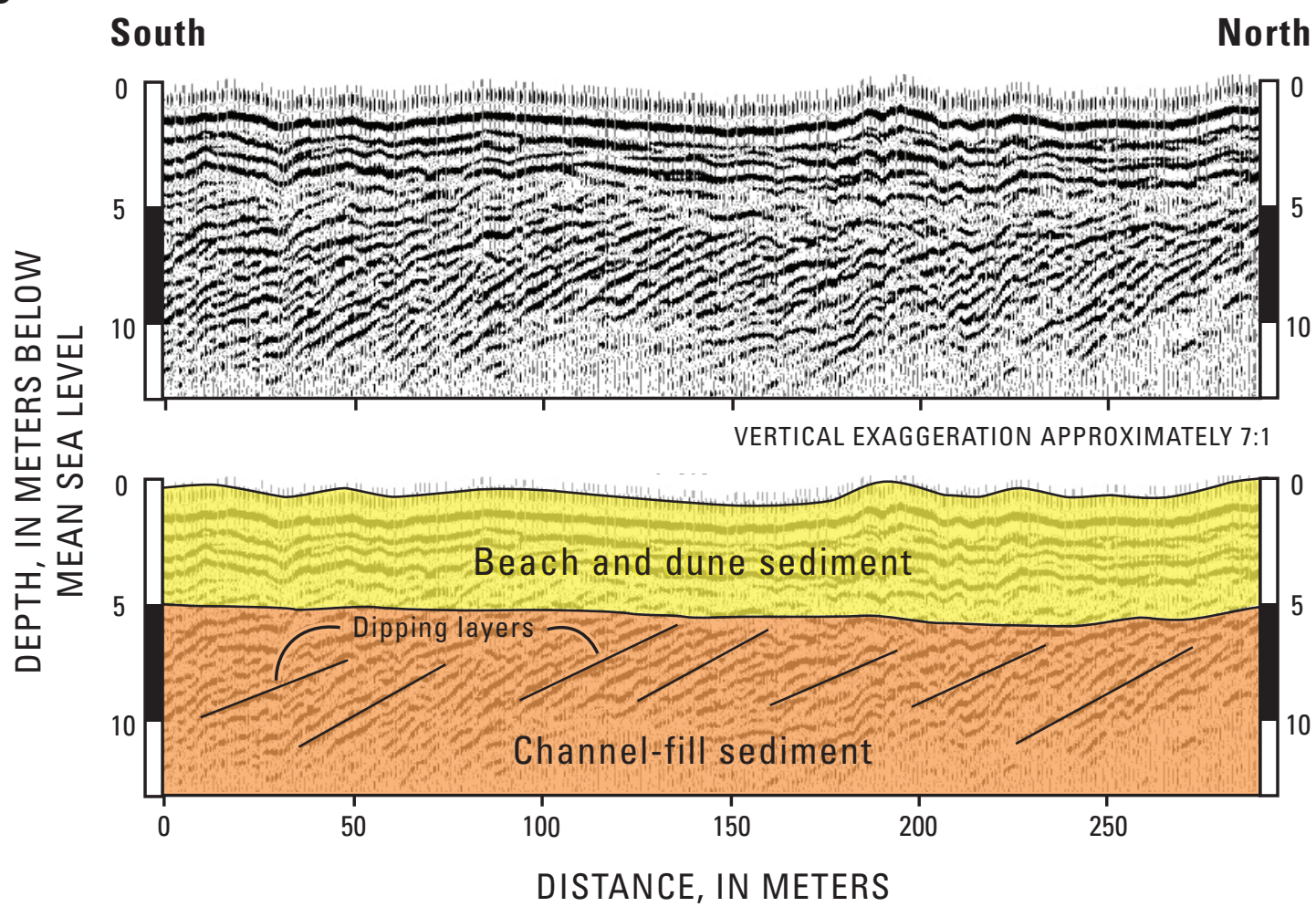

Figure 5.4. (A) Aerial photograph of the North Island spit at the southern end of the Grand Strand, showing the positions of five historical shorelines. Prominent beach ridges (small white arrows) that predate the historical record were produced as the spit grew from north to south. (B) Ground-penetrating-radar profile showing the internal structure of the spit, which consists of sandy sediment over $10 \mathrm{~m}$ thick. Steeply dipping layers in the lower unit (orange) formed as sediment, carried by south-directed longshore currents, filled the channel at the entrance to Winyah Bay. Beaches and dunes later developed on top of the channel-fill sediment, producing an upper deposit of fine sand (yellow) that exhibits wavy, nearly flat-lying layers. The calculation of sediment volume stored in the spit from 1872 to 1983 (see table 5.1) is based on the prograding upper unit and underlying channel fill. 
net surplus of sand (fig. 4.3B). Dredging records from Little River Inlet prior to the construction of jetties in 1982 show small net losses of sediment from Long Bay into Onslow Bay off the coast of North Carolina (fig. 1.3A). An average of $57,000 \mathrm{~m}^{3} / \mathrm{yr}$ of sediment was dredged from the navigation channel between 1975 and 1982 (table 5.1). This value was used to estimate sediment lost across the northern boundary by longshore transport.

\section{Losses at Tidal Inlets}

Tidal inlets function as reservoirs that temporarily store and release sediment within the regional system. Net changes in the volumes of sediment contained in the inlet systems strongly affect the stability of adjacent beaches over the short term. In addition to inlets at the boundaries of the Grand Strand, Hog and Murrells Inlets are probably sites of net sediment loss from the beach system (fig. 5.1). On the basis of dredging records for 1974 to 1978 , about $75,000 \mathrm{~m}^{3} / \mathrm{yr}$ of sediment was lost at Murrells Inlet (table 5.1). No dredging data were available for Hog Inlet to estimate sediment losses.

\section{Losses Offshore to the Inner Shelf}

Extensive areas of hardbottom dominate the inner shelf of Long Bay (figs. 2.4, 2.5). Seaward of Surfside Beach (fig. 1.3B), for example, is a nearly continuous area of rocky outcrops extending offshore for about $10 \mathrm{~km}$. Small lenses of loose sediment within this zone probably are derived from biological and mechanical erosion of the outcrops, as has been observed elsewhere in the region (Riggs and others, 1998). The near-absence of modern sediment indicates that transport of sediment from the beach to the inner shelf may be small. Alternatively, the mobile sediment may be moved quickly into deeper water beyond the limit of the survey area.

\subsection{Sediment-Transport Pathways}

The relatively minor amount of mobile sediment in Long Bay is moved by waves and currents in a complex pattern. On a broad regional scale, seafloor mapping helps us infer the long-term directions of sediment transport on the basis of geomorphic evidence and sediment distribution.
However, formulation of a quantitative sediment budget is not possible with mapping techniques alone. Most sediment movement occurs during short-lived, energetic storms. Direct observations of oceanographic processes (for example, the speed and direction of bottom currents) are needed to quantify how much and in what direction sediment is moved during a storm or series of storms. Knowledge of the actual rates and pathways of sediment transport can be used to predict patterns of erosion and accretion along the beach and determine the availability of sediment for planned beach-nourishment projects.

\section{Transport Direction Inferred from Seafloor Mapping}

Several lines of evidence indicate that sediment generally moves along the coast from north to south. First, the southerly migration of the Pee Dee River over a period of more than a million years (Baldwin and others, 2006) has shifted the major supply of fluvial sediment away from the center of the Grand Strand (fig. 3.9). Consequently, the central and northern parts of the Grand Strand now depend primarily on the reworking of relict-shoreline and inner-shelf deposits for sediment supply. Second, sediment-thickness mapping shows relatively little mobile sediment in the northern and central parts of the Grand Strand, with the largest accumulations in the south (fig. 3.5B). Third, the direction of longterm net sediment transport is inferred from lowrelief sand ridges on the inner shelf (fig. 5.5). Profile asymmetry and changes in sediment texture show current winnowing in the troughs between the sand bodies and support conceptual models of sediment moving south along the coast towards Winyah Bay. These characteristic patterns that indicative sedimenttransport pathways are being used to guide processoriented studies.

Offshore-directed losses of sediment from Grand Strand beaches are not assigned an estimate for this sediment budget. Sediment is probably transported offshore in some areas, but little data are available to prove that it moves across the shelf. Slightly elevated rocky ledges oriented nearly perpendicular to the shoreline (fig. 2.5) might divert sediment seaward and thereby contribute to locally high rates of erosion (Gayes and others, 2003). 


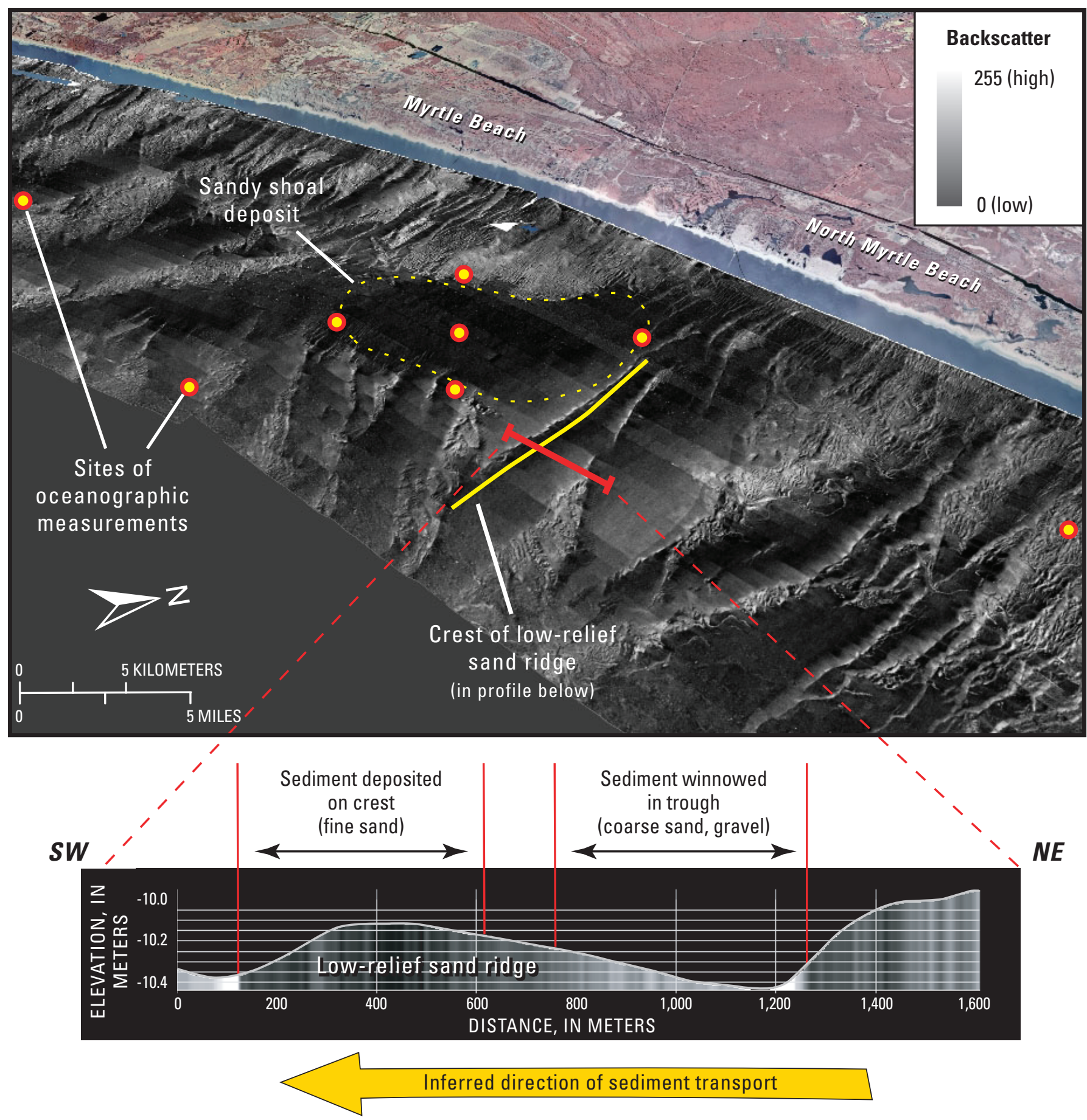

Figure 5.5. Perspective view of the inner shelf offshore of Myrtle Beach shows sidescan-sonar imagery draped over bathymetry (top). High backscatter values (light tones) generally represent rock, gravel, or coarse sand. Low backscatter values (dark tones) generally represent fine sand or muddy sediment. Oceanographic instruments were deployed at eight sites (red circles) on and near a large sandy shoal to determine the physical processes that control sediment transport around the feature. A bathymetric profile across a low-relief sand ridge shows the direction of net sediment transport (bottom). The steeper slope faces toward the southwest, and finer sediment winnowed from the trough and northeast-facing side of the ridge has left a lag of coarse sand and gravel. Fine sand has been deposited on the crest and southwest-facing side. Modified from Denny and others (2007). 


\section{Direct Observations of Sediment Transport}

An initial study in 2001 measured waves and currents for periods of over 30 days at six locations in Long Bay. The data were helpful in determining the general circulation in the bay and the response of the system to local winds (Gutierrez and others, 2006). In a second study, instruments were deployed from October 2003 to April 2004 offshore of Myrtle Beach to investigate sediment movement on the inner shelf (fig. 5.5). Measurements of winds, currents, waves, and suspended sediment concentrations were collected at eight sites in the vicinity of a large sandy shoal that lies in water depths of about $10 \mathrm{~m}$. Given the importance of finding sand resources for beach nourishment, this deposit might be suitable for sand extraction.

Before dredging the deposit, however, some important questions need to be addressed. Is the resource renewable? Will inner-shelf processes replace sediment that is mined? Will dredging change the distribution of wave energy along nearby stretches of coastline and cause unwanted erosion?

Preliminary results show that locally high winds strongly correlate with peaks in wave energy. As wind strength increases during a storm, wave heights increase (fig. 2.11). Large waves create orbital motions at the sea surface that propagate downward and oscillate along the seafloor. These motions erode bottom sediment and suspend it in the water column during storms. Suspended sediment concentrations are increased only when there are large waves; tidal currents alone are not strong enough to mobilize the sediment. A combination of wind-driven surface currents and near-bottom circulation determines the direction and magnitude of sediment transport within Long Bay. Details of the site locations, equipment specifications, all the processed data, and the processing tools are described in Sullivan and others (2005).

\subsection{Numerical Modeling}

Numerical models developed as part of the SCCES show that offshore bathymetric features, such as the sandy shoal seaward of Myrtle Beach (fig. 5.5), affect nearshore processes through the modification of waves that pass over them. The direction and magnitude of sediment transport on the inner shelf are influenced by different patterns of storms that pass through South Carolina: (1) tropical cyclones (that is, tropical storms and hurricanes), (2) cold fronts, and (3) warm fronts (fig. 5.6). Storms develop around atmospheric regions of high and low pressure that move across North America. Winds blow counterclockwise around low-pressure systems, bringing cooler air to the south and warmer air to the north. As these air masses move, they create a cold front to the south of the low pressure and a warm front that extends to the east from the low pressure.

- TROPICAL CYCLONE: Low pressure is southwest of Long Bay and moving to the north. As it passes offshore of the coast, winds initially blow out of the northeast (dashed arrow) and shift to the northwest (solid arrow). Strong winds, waves, and currents are directed generally towards the south throughout the storm. Net sediment flux along the coast is towards the southwest.

- COLD FRONT: Low pressure is northwest of Long Bay and moving to the east. A trailing cold front crosses the region and is accompanied by a change in wind direction. Wind initially blows out of the southwest (dashed arrow) and shifts to the northeast (solid arrow). More sediment is transported when the wind blows from the southwest because the larger fetch, or the area of the open ocean over which wind blows in constant speed and direction, generates stronger waves. Net sediment flux along the coast is towards the northeast.

- WARM FRONT: Low pressure is west of Long Bay and moving to the north. An extending warm front crosses the region and is accompanied by a rapid change in wind direction. Wind initially blows out of the northeast (dashed arrow) and shifts to the southwest (solid arrow). Even though the wind pattern of the warm front is opposite to that of a cold front, the fetch is larger when the winds are from the southwest. Net sediment flux along the coast is also towards the northeast.

The duration, magnitude, and frequency of the different storm types dictate the long-term sediment flux in the region. Cold fronts and warm fronts generally drive sediment transport toward the northeast; tropical storms generally drive it to the southwest (fig. 5.6). If transport is roughly equal in both directions, it provides a potential mechanism for partially preserving the sandy shoal, which somehow 
A

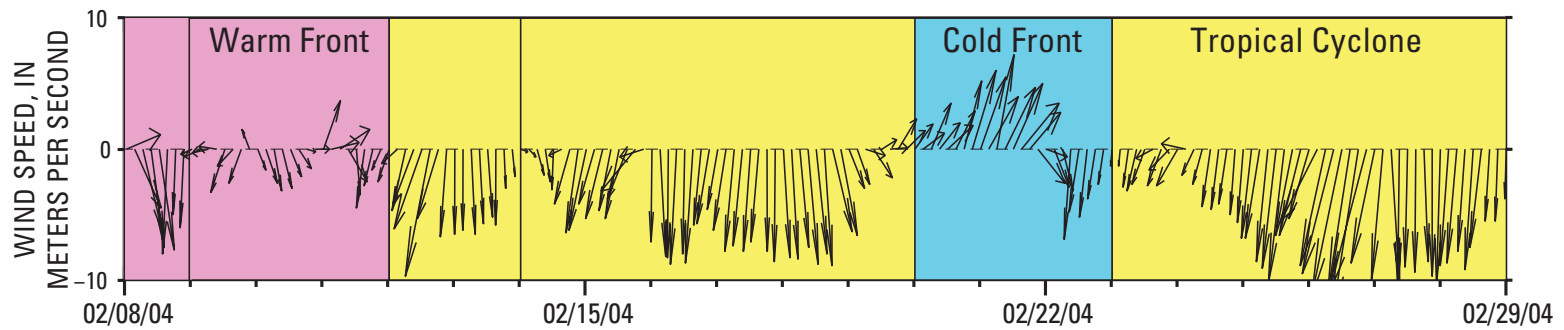

$B$
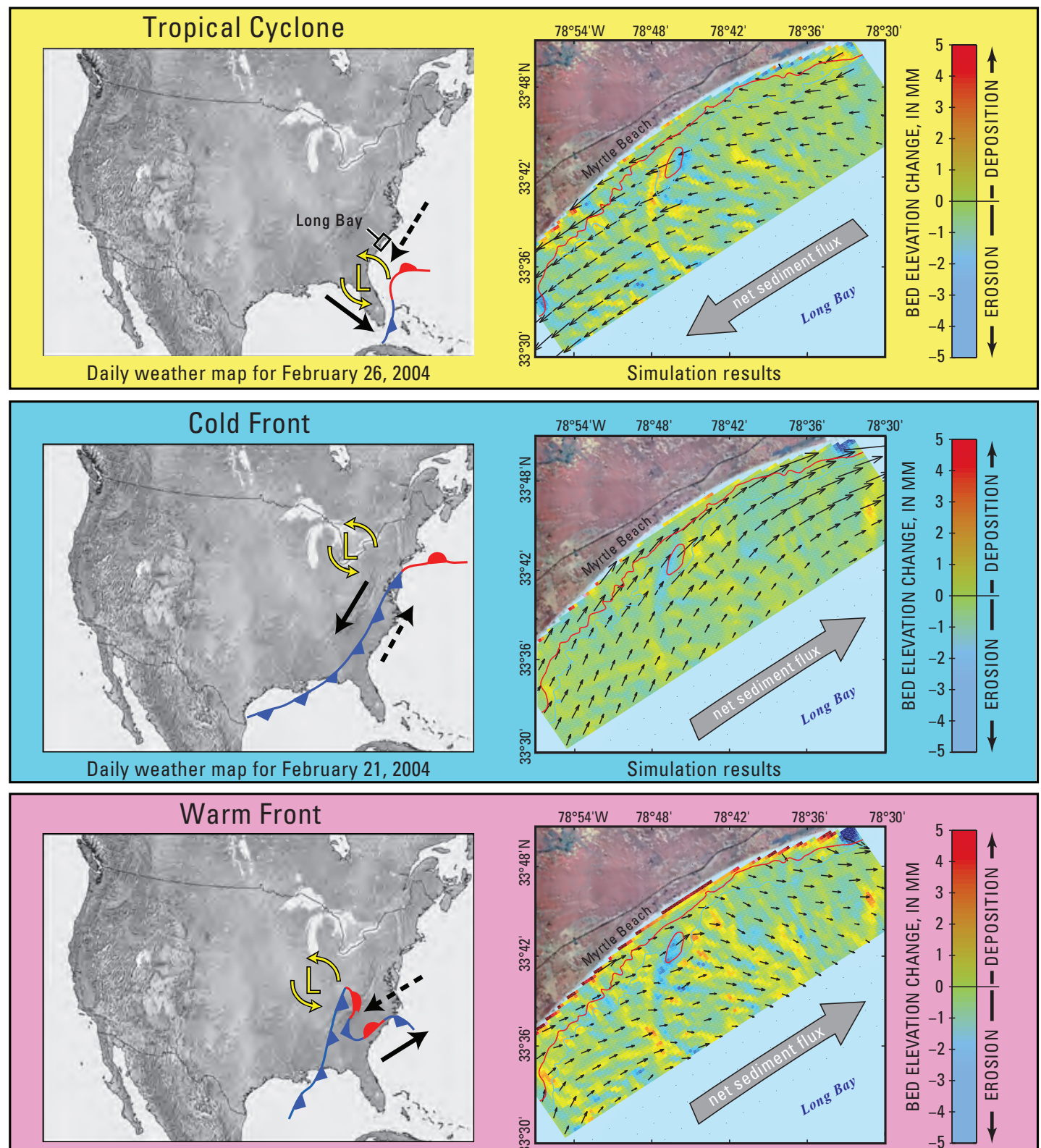

Daily weather map for February 11, 2004

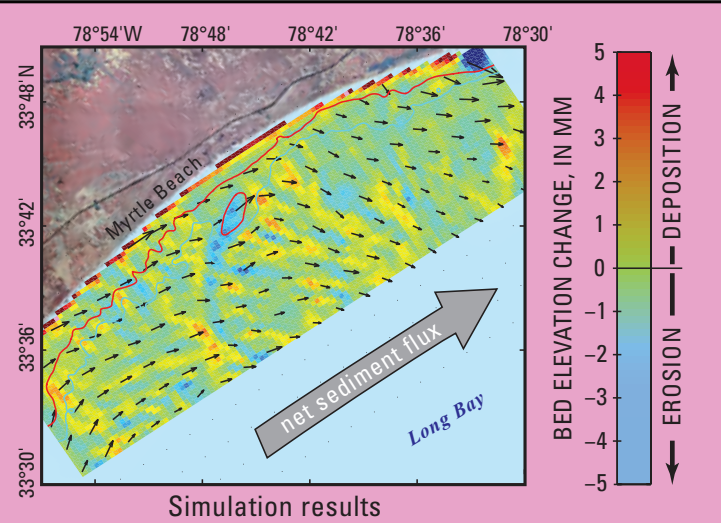

Figure 5.6. (A) Measurements of wind speed and direction collected offshore of Myrtle Beach from February 8 to 29, 2004. Additional data for this time period are shown in figure 2.11B. (B) Weather maps on the left show three different storm patterns crossing the region. Simulation results for each storm on the right show the general direction of sediment transport (arrows) and predicted areas of sediment erosion and deposition on the inner shelf (colors). The 8-m bathymetric contour is displayed in red. See main text for description of storms and predicted movement of shelf sediment. 
has survived erosion over the last 5,000 years or so since it was formed (Barnhardt and others, 2007). Instead of storms moving sediment in one consistent direction and eventually eroding the shoal, these observations suggest that storms could have shifted sediment back and forth across the shelf. Additional modeling will help us identify the oceanographic processes responsible for maintaining the shoal and explore the possible natural sediment pathways connecting the shoal to the beach.

\subsection{Summary}

In most places along the Grand Strand, the modern beach is a thin veneer of sand. As a result, it is sensitive to relatively small changes in the annual balance between sediment gains and losses. A sediment budget was constructed to determine the directions and annual rates of sediment movement within the coastal system. South of Murrells Inlet, there is clear evidence of long-term net longshore transport towards the south. North of Murrells Inlet net transport appears to be more variable. Large losses occur where sediment moving longshore is trapped by tidal inlets (Murrells and Little River), accumulates in a large spit complex (North Island), or exits the coastal compartment at the southern boundary (Winyah Bay).

Two important assumptions underlie our sediment-budget calculations. First, the budget is balanced so that the total volume of sediment in the Long Bay system remains constant. Losses of sediment must be offset by gains of new sediment. Second, the coastal system is closed and receives no sediment from adjacent coastal compartments to the north and south. Sediment is not transferred around the shoals at Cape Fear and Cape Romain. Lacking significant fluvial or longshore input, the only potential sources of new sediment are internal to the system, primarily erosion of older deposits within Long Bay. These potential sources include beach and shoreface deposits, which have been closely monitored by beach profiling, and inner-shelf deposits, which lie offshore in deeper, less accessible areas. Estimates of sediment derived from beach and shoreface erosion (table 5.1) are based on an idealized beach profile and are maximum values that are based on the assumed steady landward migration of sediment (fig. 5.2). If erosion across the idealized beach profile is uneven (fig. 4.3), however, the volume of new sediment might be significantly lower and more sediment would be assumed to originate from inner-shelf erosion to balance the budget. In either case, total sediment losses greatly exceed the estimates of new sediment derived from beach and shoreface erosion. Although the absolute amounts of sediment moving out of the beach system are unknown, erosion of the inner shelf must be an important contribution to the regional sediment budget.

Experiments using moored instruments have shown that shelf sediment responds to storms in a variety of ways. Depending on the type and path of given storm, waves and currents of differing intensity and direction can be expected. Some storms drive sediment towards the northern boundary of the system, and some drive sediment towards the southern boundary. The net result over a given year or decade will depend on the relative frequency and intensity of the different types of storms. Continued improvement of models of sediment transport within the Bay will aid us in refining the regional sediment budget and predicting future coastal response. The potential for shifts in storm frequency, intensity, and tracks that may accompany climate change can be expected to strongly affect sediment movement in the area. 
andy beaches represent a public resource

$\checkmark$ that is vitally important to the economic and environmental health of coastal communities. In northeastern South Carolina, however, the natural coastal system has been widely disturbed by human activities. The dynamic and mobile beach is progressively colliding with static infrastructure, which prevents it from migrating landward in an orderly fashion. The direct and indirect effects of shoreline migration on development in this complex system likely will increase as a result of global warming and accelerated rates of sea-level rise. Beach nourishment is the preferred method of erosion control, but experience shows that nearly all nourished beaches have a limited lifespan, so repeated infusions of new sediment are required (NRC, 1995; Trembanis and others, 1999). The long-term need for beach fill in the Grand Strand region will require improved projections of coastal-erosion rates and the identification of new sediment sources.

The SCCES has developed a comprehensive strategy to determine the factors and processes that control sediment movement in the coastal zone. The strategy consists of three distinct parts. The first part is to map the geologic framework of Grand Strand beaches and adjacent areas of shallow seafloor. The second part is to document both long-term and shortterm fluctuations in shoreline position over time. The third part is to develop a conceptual sediment budget for the coastal system, measure sediment transport at selected sites, and ultimately construct numerical models of sediment flux in the nearshore area.

Part 1 - Geologic Mapping. The geologic framework of the Grand Strand exerts strong control on the production, movement, and ultimate deposition of sediment. The degree to which geology controls sediment movement along the coast was difficult to measure until recently, because collecting data in energetic areas adjacent to the beach was not feasible; however, improvements in technology now provide efficient methods to explore and map the shallow seafloor. High-resolution maps of seafloor topography and sediment texture support conceptual models of sediment generally moving from northeast to southwest along the coast. The Pee Dee River has migrated southward for millions of years, too, as shown by a series of buried river channels mapped beneath the seafloor. This migration has shifted the major supply of fluvial sediment away from the center of the Grand Strand and thereby produced a generally sediment-limited inner shelf dominated by rocky outcrops. Geologic mapping of the inner shelf has identified large sandy deposits that represent potential sources of beach-nourishment sediment in the future.

Part 2 - Shoreline Change. Aerial photography and beach-profile measurements showed that the active beach system has been migrating landward but at different rates at different sites along the coast. Also, the rate of retreat at any single site has not been uniform over time. In Myrtle Beach, for example, substantial variations in beach-fill stability were observed where a large beach-nourishment project was completed in 1998. Areas of low stability coincided with extensive rocky outcrops mapped in shallow water just seaward of the reconstructed beaches. The outcrops appeared to interrupt sedimentdispersal pathways and alter patterns of sediment accumulation along the beach; the result was localized areas of enhanced erosion. The monitoring period (1988-present) includes some of the largest storms to affect the region, such as Hurricane Hugo (1989) and the storm named "The Storm of the Century" (1993). These storms were major erosional events that removed the thin veneer of beach sediment to the greatest extent of any storms over the last 20 years. Beach profiles measured when the beach was most deeply eroded documented the base of the active sediment layer where it overlay a rocky substrate. In many places, sediment on the modern beach is less than $1 \mathrm{~m}$ thick, even though nourishment projects 
have repeatedly placed large amounts of new sediment on the beach.

Part 3 - Ocean Processes and Sediment Budget. Ongoing efforts aim to quantify the volume of sediment moving through the coastal system and determine the role of coastal oceanographic processes that cause erosion. Time-series measurements of ocean processes help us to address questions raised by geologic mapping. For example, what is the precise role of the large sandy shoal offshore of Myrtle Beach in controlling the distribution of wave power along the shoreline? Mining the shoal to rebuild the beach might alter the height and direction of waves approaching the beach and thereby locally increase the vulnerability of the beach to erosion. Data collected during oceanographic experiments are being used to determine the sediment-transport processes responsible for shaping the shoal and adjacent shoreline. Eventually, observational data and numerical models will be used to determine regional circulation dynamics and to predict patterns of sediment flux around the shoal and adjacent surf zone.

The results of this integrated approach to investigating coastal erosion have helped municipalities and government agencies protect public health and stabilize beaches. For example, the City of North Myrtle Beach used geologic maps produced by the SCCES to design stormwater outfalls, which extend offshore so that discharge will not circulate back onto the beach and affect water quality. The results of this study generated substantial cost savings for the construction of 12 outfalls by obviating the need for expensive surveys at many potential sites. Instead, the city accessed the geologic maps and information to determine suitable locations. Every major beach-nourishment project in South Carolina over the past 10 years has relied on beach-profile data and mapping products from the SCCES (Park and others, 2009). The USACE has reduced expenses by as much as $\$ 50,000$ per year per project, depending on the shoreline length, by incorporating the study results as part of its planning process. The City of Myrtle Beach and Horry County similarly use the data to generate annual maintenance reports for nourishment projects. In this sediment-limited region, South Carolina is committed to beach nourishment to mitigate coastal erosion, and sediment is already being mined from borrow areas beyond the 3-mile limit of State waters. The regionally comprehensive framework approach described in this report supports efforts to efficiently manage coastal sediment and reliably project the long-term availability and cost of these resources.

Mapping products and data generated by the SCCES have led scientists to challenge some long-held assumptions about how beaches evolve, especially how they respond to storms and rising sea level. Most models of coastal change are based on the assumptions that waves and currents are acting on homogeneous deposits of unconsolidated sediment, and that beaches maintain a constant geometry (smooth and concave up) over time as they migrate landward. The degree to which these assumptions are violated along the Grand Strand was initially identified by the long time series of beach profiles collected in this study. The profiles clearly show that older, erosion-resistant deposits underlie the beach and inner shelf. Rock ledges exposed on the shoreface interrupt the standard concave-up profile used in the traditional models. Integration of shoreline-change studies with geologic-framework mapping conclusively demonstrates that, in many places along the Grand Strand, virtually no modern sediment is present on the shallow seafloor adjacent to the beach. The absence of this sediment highlights the relative importance of the actively eroding inner shelf and shoreface as major components of the regional sediment budget. 
Anders, F.J., and Byrnes, M.R., 1991, Accuracy of shoreline change rates as determined from maps and aerial photographs: Shore and Beach, v. 59, no. 1, p. 17-26.

Anders, F.J., Reed, D.W., and Meisburger, E.P., 1990, Shoreline movements-Report 2, Tybee Island, Georgia, to Cape Fear, North Carolina, 1851-1983: USACE Technical Report, CERC-83-1, 164 p.

Anderson, K.E., Cahoon, D.R., Gill, S.K., Gutierrez, B.T., Thieler, E.R., Titus, J.G., and Williams, S.J., 2009: Executive summary in Coastal sensitivity to sea-level rise-A focus on the mid-Atlantic region. A report by the U.S. Climate Change Science Program and the Subcommittee on Global Change Research. [J.G. Titus (coordinating lead author), K.E. Anderson, D.R. Cahoon, D.B. Gesch, S.K. Gill, B.T. Gutierrez, E.R. Thieler, and S.J. Williams (lead authors)]: U.S. Environmental Protection Agency, Washington, D.C., USA, pp. 1-8.

Baldwin, W.E., Denny, J.F., Schwab, W.C., Gayes, P.T., Morton, R.A., and Driscoll, N.W., 2007, Geologic framework studies of South Carolina's Long Bay from Little River Inlet to Winyah Bay, 1999-2003Geospatial data release: U.S. Geological Survey Open-File Report 05-1346, 1 DVD-ROM, accessed online July 1, 2007, at http://woodshole.er.usgs.gov/ pubs/of2005-1346/.

Baldwin, W.E., Morton, R.A., Denny, J.F., Dadisman, S.V., Schwab, W.C., Gayes, P.T., and Driscoll, N.W., 2004, Maps showing the stratigraphic framework of South Carolina's Long Bay from Little River to Winyah Bay: U.S. Geological Survey Open-File Report 04-1013, accessed online July 1, 2007, at http://pubs.usgs.gov/of/2004/1013/.

Baldwin, W.E., Morton, R.A., Putney, T.R., Katuna, M.P., Harris, M.S., Gayes, P.T., Driscoll, N.W., Denny, J.F., and Schwab, W.C., 2006, Migration of the Pee Dee River system inferred from ancestral paleochannels underlying the South Carolina Grand Strand and Long Bay inner shelf: Geological Society of America Bulletin, v. 118, no. 5/6, p. 533-549.

Barnhardt, W.A., Denny, J.F., Baldwin, W.E., Schwab, W.C., Morton, R.A., Gayes, P.T., and Driscoll, N.W., 2007, Geologic framework of the Long Bay inner shelf-Implications for coastal evolution in South Carolina: New Orleans, La., Proceedings of Coastal Sediments 2007, CD-ROM13.
Beach, D., 2002, Coastal sprawl-The effects of urban design on aquatic ecosystems in the United States: Arlington, Va., Pew Oceans Commission, 40 p., accessed online July 1, 2007, at http://www.pewtrusts. org/resource library.aspx

Bothner, M.H., and Butman, Bradford, 2007, Processes influencing the transport and fate of contaminated sediments in the coastal ocean-Boston Harbor and Massachusetts Bay, U.S. Geological Survey Circular 1302, p. 1-89.

Brennan, J.W., 1991, Meteorological summary of Hurricane Hugo: Journal of Coastal Research, SI 8, p. 1-12.

Brown, P.J., Ehrlich, R., and Colquhoun, D.J., 1980, Origins of patterns of quartz sand types on the southeastern United States continental shelf and implications on contemporary shelf sedimentation-Fourier grain shape analysis: Journal of Sedimentary Petrology, v. 50, no. 4, p. 1095-1100.

Chasten, M.A., 1992, Coastal response to a dual jetty system at Little River Inlet, North and South Carolina: U.S. Army Corps of Engineers Miscellaneous Paper, CERC-92-2, $56 \mathrm{p}$.

Climate Change Science Program (CCSP), 2009, Coastal sensitivity to sea-level rise-A focus on the midAtlantic region. A report by the U.S. Climate Change Science Program and the Subcommittee on Global Change Research. [J.G. Titus (coordinating lead author), K.E. Anderson, D.R. Cahoon, D.B. Gesch, S.K. Gill, B.T. Gutierrez, E.R. Thieler, and S.J. Williams (lead authors)]: U.S. Environmental Protection Agency, Washington, D.C., USA, 320 p.

Colquhoun, D.J., 1995, A review of Cenozoic evolution of the southeastern United States Atlantic coast north of the Georgia Trough: Quaternary International, v. 26, p. $35-41$.

Colquhoun, D.J., Johnson, G.H., Peebles, P.C., Huddlestun, P.F., and Scott, T., 1991, Quaternary geology of the Atlantic Coastal Plain, in Morrison, R.B., ed., The geology of North America, Quaternary Nonglacial Geology - Conterminous U.S.: Boulder, Colo., Geological Society of America, v. K-2, p. 629-650.

Dean, R.G., 1991, Equilibrium beach profilesCharacteristics and applications: Journal of Coastal Research, v. 7, no. 1, p. 53-84.

Denison, P., 1998, Beach renourishment/groin field construction project-Bald Head Island, NC: Shore and Beach, v. 66, no. 1, p. 2-9. 
Denny, J.F., Baldwin, W.E., Schwab, W.C., Gayes, P.T., Morton, R.A., and Driscoll, N.W., 2007, Morphology and texture of modern sediments on the inner shelf of South Carolina's Long Bay from Little River Inlet to Winyah Bay: U.S. Geological Survey Open-File Report 2005-1345, accessed online February 1, 2008, at http://pubs.usgs.gov/of/2005/1345/.

Dolan, R., Anders, F., and Kimball, S., 1985, Coastal erosion and accretion-National Atlas of the United States of America: Reston, Va., U.S. Geological Survey, 1 sheet.

Douglas, B.C., 1997, Global sea rise-A redetermination: Surveys in Geophysics, v. 18, p. 279-292.

DuBar, J.R., Johnson, H.S., Jr., Thom, B., and Hatchell, W.O., 1974, Neogene stratigraphy and morphology, south flank of the Cape Fear Arch, North and South Carolina, in Oaks, R.Q., and DuBar, J.R., eds., PostMiocene stratigraphy, central and southern Atlantic Coastal Plain: Logan, Utah, Utah State University Press, p. 139-173.

Emanuel, K., 2005, Increasing destructiveness of tropical cyclones over the last 30 years: Nature, v. 436, p. 686-688.

Fairbanks, R.G., 1989, A 17,000-year glacio-eustatic sea level record-Influence of glacial melting on the Younger Dryas event and deep-ocean circulation: Nature, v. 342, p. 637-642.

Gayes, P.T., Schwab, W.C., Driscoll, N.W., Morton, R.A., Baldwin, W.E., Denny, J.F., Wright, E.E., Harris, M.S., Katuna, M.P., Putney, T.R., and Johnstone, E., 2003, Sediment dispersal pathways and conceptual sediment budget for a sediment starved embayment, Long Bay, South Carolina: Clearwater Beach, Fla., Proceedings of Coastal Sediments '03, 14 p., CD-ROM.

Gohn, G.S., 1988, Late Mesozoic and early Cenozoic geology of the Atlantic Coastal Plain, North Carolina to Florida, in Sheridan, R.E., and Grow, J.A., eds., The geology of North America, v. 1-2, The Atlantic continental margin, U.S.: Boulder, Colo., The Geological Society of America, p. 107-130.

Gutierrez, B.T., Voulgaris, G., and Work, P.A., 2006, Cross-shore variation of wind-driven flows on the inner shelf in Long Bay, South Carolina, United States: Journal of Geophysical Research, v. 111, C03015, $16 \mathrm{p}$.
Hayes, M.O., 1994, The Georgia Bight barrier system, in Davis, R.A., ed., Geology of Holocene barrier island systems: New York, N.Y., Springer-Verlag, p. 233-304.

Horton, J.W., Jr., and Zullo, V.A., 1991, An introduction to the geology of the Carolinas, in Horton J.W., Jr., and Zullo, V.A., eds., The geology of the Carolinas: Carolina Geological Society 50th anniversary volume, University of Tennessee Press, p. 1-10.

Hubbard, D.K., Barwis, F.L., Stephen, M.F., and Hayes, M.O., 1977a, Beach erosion inventory of Horry, Georgetown, and Beaufort Counties, South Carolina: Charleston, S.C., South Carolina Sea Grant, South Carolina Sea Grant Technical Report, no. 8, 58 p.

Hubbard, D.K., Hayes, M.O., and Brown, P.J., 1977b, Beach erosion trends along the South Carolina coast, in Coastal Sediments '77, Fifth Symposium of the Waterway, Port, Coastal and Ocean Division: New York, N.Y., American Society of Civil Engineers, p. 197-814.

Intergovernmental Panel on Climate Change (IPCC), 2007, Climate change 2007-The Physical Science Basis. Contribution of working group I to the fourth assessment report of the Intergovernmental Panel on Climate Change: Solomon, S., Qin, D., Manning, M., Chen, Z., Marquis, M., Averyt, K.B., Tignor, M., and Miller, H.L., eds.: Cambridge, UK and New York, N.Y., Cambridge University Press.

Klitgord, K.D., Hutchinson, D.R., and Schouten, H., 1988, U.S. Atlantic continental margin-Structural and tectonic framework, in Sheridan, R.E., and Grow, J.A., eds., The geology of North America, v. 1-2, The Atlantic continental margin, U.S.: Boulder, Colo., The Geological Society of America, p. 19-55.

Komar, P.D., 1996, The budget of littoral sedimentsConcepts and applications: Shore and Beach, v. 64, p. 18-26.

Lambeck, K., and Chappell, J., 2001, Sea-level change through the last glacial cycle: Science, v. 292, p. 679-686.

Lennon, G., Neal, W.J., Bush, D.M., Pilkey, O.H., Stutz, M., and Bullock, J., 1996, Living with the South Carolina Coast: Durham, N.C., Duke University Press, $241 \mathrm{p}$.

McCartan, L., Lemon, E.M., Jr., and Weems, R.E., 1984, Geologic map of the area between Charleston and Orangeburg, South Carolina: U.S. Geological Survey Map I-1472, scale 1:250,000. 
Meade, R.H., 1982, Sources, sinks and storage of river sediments in the Atlantic drainage of the United States: Journal of Geology, v. 90, p. 235-252.

Meade, R.H., and Trimball, S.W., 1974, Changes in sediment load in rivers of the Atlantic drainage of the United States since 1900 - Effects of man on the interface of the hydrological system with the physical environment: International Association of Hydrological Sciences, Publication no. 113, p. 99-104.

Miller, K.G., Kominz, M.A., Browning, J.V., Wright, J.D., Mountain, G.S., Katz, M.E., Sugarman, P.J., Cramer, B.S., Christie-Blick, N., and Pekar, S.F., 2005, The Phanerozoic record of global sea-level change: Science, v. 310, p. 1293-1298.

Moran, K., Backman, J., Brinkhuis, H., Clemens, S.C., Cronin, T., Dickens, G.R., Eynaud, F., Gattacceca, J., Jakobsson, M., Jordan, R.W., Kaminski, M., King, J., Koc, N., Krylov, A., Martinez, N., Matthiessen, J., McInroy, D., Moore, T.C., Onodera, J., O’Regan, M., Pälike, H., Rea, B., Rio, D., Sakamato, T., Smith, D.C., Stein, R., St. John, K., Farrell, F., Frank, M., Kubik, P., Jokat, W., and Kristoffersen, Y., 2006, The Cenozoic paleoenvironment of the Arctic Ocean: Nature, v. 441, p. 601-605.

Morton, R.A., and Miller, T.L., 2005, National assessment of shoreline change-Part 2, Historical shoreline changes and associated coastal land loss along the U.S. southeast Atlantic coast: U.S. Geological Survey Open-File Report 05-1410, 40 p., accessed on July 1, 2007, at http://pubs.usgs. gov/of/2005/1401/.

Myrtle Beach Chamber of Commerce, 2008, Statistical abstract for the Myrtle Beach area of South Carolina: Myrtle Beach, S.C., The City of Myrtle Beach, accessed online February 12, 2008, at http://www.myrtlebeachinfo.com/chamber/research/ data_and_statistics.htm

National Research Council (NRC), 1995, Beach nourishment and protection: Washington, D.C., National Academy Press, 334 p.

Nelson, D.D., 1991, Factors effecting beach morphology changes caused by Hurricane Hugo, northern South Carolina: Journal of Coastal Research, SI 8, p. $163-181$.

Owens, J.P., 1989, Geologic map of the Cape Fear region-Florence $1^{\circ} \times 2^{\circ}$ quadrangle and northern half of the Georgetown $1^{\circ} \times 2^{\circ}$ quadrangle, North Carolina and South Carolina: U.S. Geological Survey, Miscellaneous Investigations Series Map I-1948-A, scale 1:250,000.
Owens, J.P., and Gohn, G.S., 1985, Depositional history of the Cretaceous series in the U.S. Atlantic Coastal Plain-Stratigraphy, paleoenvironments, and tectonic controls of sedimentation, in Poag, C.W., ed., Geologic evolution of the United States Atlantic margin: New York, N.Y., Van Nostrand Reinhold, p. 25-86.

Palmer, A.R., and Geissman, J., compilers, 1999, Geologic time scale: Product code CTS004, Geological Society of America.

Park, J.Y., Gayes, P.T., and Wells, J.T., 2009, Monitoring beach renourishment along the sediment-starved shoreline of Grand Strand, South Carolina: Journal of Coastal Research, v. 25, p. 336-349.

Patchineelam, S.M., Kjerve, B., and Gardner, L.R., 1999, A preliminary sediment budget for the Winyah Bay estuary, South Carolina, USA: Marine Geology, v. 162 , p. $133-144$.

Pfeffer, W.T., Harper, J.T., and O’Neel, S., 2008, Kinematic constraints on glacier contributions to 21st-century sea-level rise: Science, v. 321, no. 5894, p. 1340-1343.

Popenoe, P., 1985, Cenozoic depositional and structural history of the North Carolina margin from seismicstratigraphic analyses, in Poag, C.W., ed., Geologic evolution of the United States Atlantic Margin: New York, N.Y., Von Nostrand Reinhold Co., p. 125-188.

Popenoe, P., Henry, V.J., and Idris, F.M., 1990, Gulf trough-The Atlantic connection: Geology, v. 15, p. 327-332.

Putney, T.R., Katuna, M.P., and Harris, M.S., 2004, Subsurface stratigraphy and geomorphology of the Grand Strand, Georgetown and Horry Counties, South Carolina: Southeastern Geology, v. 42, no. 4, p. 217-236.

Rahmstorf, S., 2007, A semi-empirical approach to projecting future sea-level rise: Science, v. 315, no. 5810 , p. $368-370$.

Riggs, S.R., Ambrose, W.G., Cook, J.W., and Snyder, S.W., 1998, Sediment production on sediment-starved continental margins - The interrelationship between hardbottoms, sedimentological and benthic community processes, and storm dynamics: Journal of Sedimentary Petrology, v. 68, no. 1, p. 155-168. 
Riggs, S.R., and Belknap, D.F., 1988, Upper Cenozoic processes and environments of continental margin sedimentation-Eastern United States, in Sheridan, R.E., and Grow, J.A., eds., The geology of North America, v. 1-2, The Atlantic continental margin, U.S.: Boulder, Colo., The Geological Society of America, p. 131-176.

Sallenger, A.H., Jr., Krabill, W.B., Swift, R.N., Brock, J., List, J., Hansen, M., Holman, R.A., Manizade, S., Sontag, J., Meredith, A., Morgan, K., Yunkel, J.K., Frederick, E.B., and Stockdon, H., 2003, Evaluation of airborne topographic LIDAR for quantifying beach changes: Journal of Coastal Research, v. 19, no. 1, p. 125-133.

Shalowitz, A.L., 1964, Shoreline and sea boundaries: Washington, D.C., U.S. Department of Commerce, Coast and Geodetic Survey, v. 1, Pub. 10-1, 420 p.

South Carolina Department of Health and Environmental Control-Ocean and Coastal Resource Management (SCDNR-OCRM), 1995-2006, State of the beaches report (published annually): Charleston, S.C., South Carolina Department of Health and Environmental Control, Office of Ocean and Coastal Resource Management, accessed online July 1, 2007, at http:// www.scdhec.gov/environment/ocrm/pubs/reports.htm

South Carolina Department of Natural Resources - State Climatology Office (SCDNR-SCO), 2007, Hurricanes affecting South Carolina: Columbia, S.C., South Carolina Department of Natural Resources - State Climatology Office, accessed online February 12, 2008, at http://www.dnr.sc.gov/climate/sco/.

Stockdon, H.F., Sallenger, A.H., List, J.H., and Holman, R.A., 2002, Estimation of shoreline position and change using airborne topographic LIDAR data: Journal of Coastal Research, v. 18, no. 3, p. 502-513.

Sullivan, C.M., Warner, J.C., Martini, M.A., Voulgaris, G., Work, P.A., Haas, K.A., and Hanes, D., 2006, South Carolina Coastal Erosion Study data report for observations-October 2003-April 2004: U.S. Geological Survey Open-File Report 2005-1429, accessed online February 12, 2008, at http://woodshole.er.usgs.gov/pubs/of2005-1429/start.html

Thieler, E.R., and Hammar-Klose, E.S., 1999, National assessment of coastal vulnerability to future sea-level rise-Preliminary results for the U.S. Atlantic Coast: U.S. Geological Survey Open-File Report 99-593, 1 sheet, accessed online July 1, 2007, at http://pubs. usgs.gov/of/of99-593/.
Thieler, E.R., and Hammar-Klose, E.S., 2000a, National assessment of coastal vulnerability to future sea-level rise-Preliminary results for the U.S. Gulf of Mexico Coast: U.S. Geological Survey Open-File Report 00-179, 1 sheet, accessed online July 1, 2007, at http://pubs.usgs.gov/of/of00-179/.

Thieler, E.R., and Hammar-Klose, E.S., 2000b, National assessment of coastal vulnerability to future sea-level rise - Preliminary results for the U.S. Pacific Coast: U.S. Geological Survey Open-File Report 00-178, 1 sheet, accessed online July 1, 2007, at http://pubs. usgs.gov/of/of00-178/.

Thieler, E.R., Martin, D., and Ergul, A., 2003, The Digital Shoreline Analysis System, version 2.0 Shoreline change measurement software extension for ArcView: U.S. Geological Survey Open-File Report 03-076, accessed online July 1, 2007, at http://woodshole.er.usgs.gov/project-pages/dsas/ version $2 /$.

Thieler, E.R., Pilkey, O.H., Young, R.S., Bush, D.M., and Chai, F., 2000, The use of mathematical models to predict beach behavior for U.S. coastal engineeringA critical review: Journal of Coastal Research, v. 16, no. 1, p. 48-70.

Trembanis, A.C., Pilkey, O.H., and Valverde, H.R., 1999, Comparison of beach nourishment along the U.S. Atlantic, Great Lakes, Gulf of Mexico, and New England shorelines: Coastal Management, v. 27, p. 329-340.

U.S. Census Bureau, 2008, South Carolina quick facts-Horry County, South Carolina: Washington D.C., U.S. Census Bureau, accessed online February 13, 2008, at http:/quickfacts.census.gov/ qfd/states/45/45051.html

Webster, P.J., Holland, G.J., Curry, J.A., and Chang, H.R., 2005, Changes in tropical cyclone number, duration, and intensity in a warming environment: Science, v. 309, p. 1844-1846.

Wehmiller, J.F., York, L.L., and Bart, M.L., 1995, Amino acid racemization geochronology of reworked Quaternary mollusks on U.S. Atlantic coast beachesImplications for chronostratigraphy, taphonomy, and coastal sediment transport: Marine Geology, v. 124, no. 1-4, p. 303-337.

Winker, C.D., and Howard, J.D., 1977, Correlation of tectonically deformed shorelines on the southern Atlantic coastal plain: Geology, v. 5, no. 2, p. $123-127$. 


\section{A}

acoustics The study of sound, particularly the generation, propagation, and reception of mechanical waves and vibrations.

\section{B}

backscatter The scattering of acoustic energy.

bathymetry The measurement of depths of bodies of water (in this report, seafloor topography).

barrier island An elongated sandy island that is roughly parallel to the mainland shore.

beachrock Partially cemented sedimentary rock that consists of sandy sediment and shell fragments and forms in the intertidal zone.

berm A sandy, nearly horizontal step-like feature on the backshore of a beach.

\section{C}

coastal compartment A geographically defined segment of coastline in which sediment gains and losses are estimated for the purpose of calculating sediment budgets.

coastal plain The relatively flat, low-lying physiographic province that extends landward of the shoreline to the Piedmont physiographic province along the U.S. Atlantic Margin.

continental crust The solid, outermost layer or shell of the Earth that underlies the continents and continental shelves.

continental margin The ocean floor that is between the shoreline and the abyssal floor, including the continental shelf, slope, and rise.

continental shelf The submerged, gently sloping portion of the continental margin that extends seaward of the shoreline to the continental slope.

\section{D}

dip The angular tilt or incline of a geologic feature or units.

dune A low mound, ridge, or hill composed of wind-blown sediment.

\section{E}

escarpment A relatively straight, cliff-like face or steep slope of considerable linear extent formed by faulting or erosion. estuary A water body located at the intersection of a river or stream with the sea, where freshwater mixes with saltwater and tidal effects are evident.

\section{$\mathbf{F}$}

fault A fracture or zone of fractures within rocks that show evidence of relative movement.

fetch The area of the open ocean over which wind blows at a constant speed and direction, creating a wave system.

fluvial Refers to rivers and streams.

\section{G}

geographic information system (GIS) A computer-based system for capturing, storing, analyzing, managing, and presenting geospatial data.

geologic framework Refers to the underlying geologic setting, structure, and lithology (rock/sediment type) in a given area.

geomorphology The study of landforms and the processes that create them.

ground-penetrating radar (GPR) A geophysical method that uses pulses of electromagnetic energy to image the subsurface.

H

hardbottom Rocky areas of seafloor with little to no sediment cover.

hiatus A break or interruption in the continuity of the geologic record, such as the time interval not represented by rocks or sediments along an unconformity.

highstand The uppermost topographic position or elevation on land reached by sea level during a specific period in time.

I

insonify To illuminate an area of the seafloor with sound energy, as with a sonar.

L

light detection and ranging (LIDAR) A method of topographic surveying, generally from aircraft, that uses pulses of laser light.

longshore current A shore-parallel current formed by breaking waves that approach the coast at an angle.

longshore transport The movement of sediment driven parallel to the shoreline by longshore currents. 


\section{M}

mainland-attached beach A beach that is backed by dry land; not separated from the mainland by a open body of water.

microtidal Tidal range of less than $2 \mathrm{~m}$.

\section{N}

nearshore marine The portion of the inner continental shelf that extends from the shoreline to water depths of about $10 \mathrm{~m}$.

\section{P}

paleochannel An ancient incision that was cut by a stream or river and filled by younger sediments.

profile of equilibrium A theoretical term that that describes a generally concave-up surface formed by waves breaking across a bed of uniform, unconsolidated sediment.

\section{$\mathbf{R}$}

rift A long, narrow zone where the Earth's crust and lithosphere are being pulled apart.

\section{S}

salt marsh Vegetated intertidal wetlands that form in protected environments, such as behind barrier islands.

sand fence Evenly spaced, wooden vertical slats that are approximately four feet in height, and are designed to build sand dunes by trapping windblown sand and to protect existing dunes and vegetation.

scarp Abbreviated form of escarpment.

seawall An artificial structure built along a coast to protect buildings and infrastructure from coastal erosion, but commonly resulting in loss of the dry beach.

sediment budget An inventory or accounting of the inputs (gains), outputs (losses), and storage of sediment within a coastal compartment.

sedimentary rock A major group of rocks, including limestone, sandstone, conglomerate, and shale, that generally form by the cementation of layered deposits of sediment.

shoal A submerged ridge, bank, or bar that consists of or is covered by sandy, unconsolidated sediment and stands in relief on the seafloor.

shoreface The narrow, shallow part of the inner continental shelf adjacent to shore. Waves regularly agitate the bottom within the shoreface. sonar Acronym for SOund Navigation And Ranging. A method that uses sound waves to detect the presence and location of submerged objects.

spit A small point, low tongue, or narrow embankment of land that extends from the mainland, or an island that is composed of sand deposited by longshore sediment transport.

storm surge An abnormal, sudden rise in sea level generated by large waves and low atmospheric pressure that accompany a storm at landfall.

swash Flat, gently sloping areas of beach over which waves uprush and backwash. In South Carolina, swashes are broad, low-relief channels that drain water from the upland across the beach.

subaerial erosion Erosion by wind, rain, and other processes that operate in the open air or immediately adjacent to the land surface.

\section{$\mathbf{T}$}

tectonics A field of geologic study concerned with structures within the Earth's crust and the particular forces and movements that create them.

tidal inlet An opening in the shoreline, such as between two barrier islands, that connects bays or lagoons to the open ocean and is maintained by tidal currents.

topographic sheet (T-Sheet) Surveys of the topography of a land surface; typically depicts the mean high-water line, which is used to define historical shoreline positions.

topography The general configuration of any part of the Earth's surface, including relief and the position of natural and artificial features.

truncation The eroding or beveling of the top of a geologic unit or landform.

two-way traveltime The time it takes an outgoing acoustic (or radar) pulse to travel from the source to the target and back to the receiver.

\section{U}

unconformity A substantial break or gap in the geologic record where a surface of erosion or nondeposition separates geologic units of different ages.

unconsolidated Loose sediment; particles not cemented together. 
Prepared by the Pembroke Publishing Service Center. Edited by Mary S. Ashman.

Graphics by Christine T. Mendelsohn and Mark V. Bonito. Layout and design by Ann Marie Squillacci.

For more information concerning this report, contact: U.S. Geological Survey

Woods Hole Coastal and Marine Science Center

384 Woods Hole Road

Quissett Campus

Woods Hole, MA 02543

wbarnhardt@usgs.gov

or visit our Web site at: http://woodshole.er.usgs.gov/ 
응

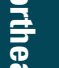

